\title{
Looking back to move forward: a twenty- year audit of herpes zoster in Asia-Pacific
}

Liang-Kung Chen ${ }^{1,2^{*}}$, Hidenori Arai ${ }^{3}$, Liang-Yu Chen ${ }^{1}$, Ming-Yueh Chou ${ }^{2,4}$, Samsuridjal Djauzi ${ }^{5}$, Birong Dong ${ }^{6}$, Taro Kojima ${ }^{7}$, Ki Tae Kwon ${ }^{8}$, Hoe Nam Leong ${ }^{9}$, Edward M. F. Leung ${ }^{10}$, Chih-Kuang Liang ${ }^{2,4,11}$, Xiaohong Liu ${ }^{12}$, Dilip Mathai ${ }^{13}$, Jiun Yit Pan ${ }^{14}$, Li-Ning Peng ${ }^{1,2}$, Eduardo Rommel S. Poblete ${ }^{15}$, Philip J. H. Poi ${ }^{16}$, Stewart Reid ${ }^{17}$, Terapong Tantawichien ${ }^{18}$ and Chang Won Won ${ }^{19}$

\begin{abstract}
Background: Herpes zoster $(\mathrm{HZ})$ is a prevalent viral disease that inflicts substantial morbidity and associated healthcare and socioeconomic burdens. Current treatments are not fully effective, especially among the most vulnerable patients. Although widely recommended, vaccination against $\mathrm{HZ}$ is not routine; barriers in Asia-Pacific include long-standing neglect of adult immunisation and sparse local data. To address knowledge gaps, raise awareness, and disseminate best practice, we reviewed recent data and guidelines on $\mathrm{HZ}$ from the Asia-Pacific region.

Methods: We searched PubMed, Scopus, and World Health Organization databases for articles about HZ published from 1994 to 2014 by authors from Australia, China, Hong Kong, India, Indonesia, Japan, Korea, Malaysia, New Zealand, the Philippines, Singapore, Taiwan, Thailand, and Vietnam. We selected articles about epidemiology, burden,

complications, comorbidities, management, prevention, and recommendations/guidelines. Internet searches retrieved additional $\mathrm{HZ}$ immunisation guidelines.

Results: From 4007 retrieved articles, we screened-out 1501 duplicates and excluded 1264 extraneous articles, leaving 1242 unique articles. We found guidelines on adult immunisation from Australia, India, Indonesia, Malaysia, New Zealand, the Philippines, South Korea, and Thailand.

$\mathrm{HZ}$ epidemiology in Asia-Pacific is similar to elsewhere; incidence rises with age and peaks at around 70 years - lifetime risk is approximately one-third. Average incidence of 3-10/1000 person-years is rising at around 5\% per year. The principal risk factors are immunosenescence and immunosuppression. $\mathrm{HZ}$ almost always causes pain, and post-herpetic neuralgia is its most common complication. Half or more of hospitalised $\mathrm{HZ}$ patients have post-herpetic neuralgia, secondary infections, or inflammatory sequelae that are occasionally fatal. These disease burdens severely diminish patients' quality of life and incur heavy healthcare utilisation.

Conclusions: Several countries have abundant data on HZ, but others, especially in South-East Asia, very few. However, Asia-Pacific countries generally lack data on $\mathrm{HZ}$ vaccine safety, efficacy and cost-effectiveness. Physicians treating HZ and its complications in Asia-Pacific face familiar challenges but, with a vast aged population, Asia bears a unique and growing burden of disease. Given the strong rationale for prevention, most adult immunisation guidelines include $\mathrm{HZ}$ vaccine, yet it remains underused. We urge all stakeholders to give higher priority to adult immunisation in general and $\mathrm{HZ}$ in particular.
\end{abstract}

Keywords: Asia-Pacific, Complications, Epidemiology, Healthcare burden, Herpes zoster, Immunisation, Management, Post-herpetic neuralgia, Prevention, Vaccine

\footnotetext{
*Correspondence: Ikchen2@vghtpe.gov.tw

${ }^{1}$ Center for Geriatrics and Gerontology, Taipei Veterans General Hospital, No.

201, Sec. 2, Shih-Pai Rd., Taipei 11217, Taiwan

${ }^{2}$ Aging and Health Research Center, National Yang Ming University, Taipei,

Taiwan

Full list of author information is available at the end of the article
} 


\section{Background}

Herpes zoster (HZ) is a prevalent and debilitating viral disease that often causes serious complications and proves challenging to treat. Consequently, $\mathrm{HZ}$ results in substantial morbidity, healthcare expenditure, loss of productivity, and diminished quality of life (QoL). Older people bear the greatest burden of disease, which is increasing as populations age. Despite a strong rationale for prevention, availability of an effective vaccine, and guidelines recommending $\mathrm{HZ}$ immunisation, vaccination has not become routine practice. One reason was limited availability of $\mathrm{HZ}$ vaccine after its launch in 2006 [1, 2]. Although an ample supply was restored, a fundamental barrier in Asia is long-standing neglect of preventive adult healthcare. Since Ilina Isahak highlighted this issue in 2000 [3], progress been limited and adult immunisation is still not given the priority that it merits $[4,5,6]$. Moreover, existing HZ immunisation guidelines are based on evidence from Western populations, which creates a perceptual barrier to changing management practices in Asia. Conversely, more locally-relevant data may promote guideline implementation; however, many Asian countries lack such data [7]. To address these concerns, we systematically reviewed literature on $\mathrm{HZ}$ from the Asia-Pacific region. Our objectives were: 1) To provide a comprehensive overview of the epidemiology, burden, and current management of $\mathrm{HZ}$; 2) To disseminate best practice in $\mathrm{HZ}$ immunisation; and 3) To provide an up-to-date source of reference and information for stakeholders concerned with reducing the burden of $\mathrm{HZ}$ in Asia-Pacific. This review summarises our key findings and recommendations.

\section{Methodology}

\section{Literature search strategy}

We reviewed literature on $\mathrm{HZ}$ published over 21 years by authors from 14 Asia-Pacific countries. We searched three databases: PubMed (United States [US] National Library of Medicine National Institutes of Health), Scopus (Elsevier), and the World Health Organization (WHO) Global Health Library Regional Indexes. PubMed and Scopus searches used the search term 'zoster' in title, abstract, and author keywords fields, AND the term 'country name' in the affiliation field. The countries/regions were: Australia, China, Hong Kong, India, Indonesia, Japan, Korea, Malaysia, New Zealand, the Philippines, Singapore, Taiwan, Thailand, and Vietnam OR Viet Nam. WHO searches used the terms 'country name' AND 'zoster'. Searches were limited to articles with abstracts in English published electronically since 1 January 1994 and before 31 December 2014; alerts were set to capture eligible articles added to PubMed and Scopus after the initial search dates.

We performed separate internet searches for guidelines on HZ immunisation. These used the country names and also vernacular terms for their inhabitants, eg, Thai,
Filipino, Malay, combined with the terms herpes zoster, guidelines, recommendations, adult immunisation, vaccine, vaccination.

\section{Data management}

PubMed and Scopus results were downloaded in Comma Separated Value format then saved to Microsoft Excel files. WHO Global Health Library searches were exported as text files then imported into Microsoft Excel. Results from each database were screened to remove duplicates before entering the results for each country into a Microsoft Excel workbook. Duplicates between databases were identified by using conditional formatting to highlight entries with the same title. Duplicates between countries were identified similarly, by highlighting entries with the same database identity codes.

\section{Inclusion and inclusion criteria}

We included articles about four topics: epidemiology and burden; complications and comorbidities; management and prevention; and recommendations/guidelines. We excluded articles about: subjects only younger than 18 , or from another country; primary varicella zoster virus (VZV) infection or not specifying that VZV infection was reactivated; negative disease associations, cases of coincidental $\mathrm{HZ}$, or diseases other than $\mathrm{HZ}$; extraneous research topics, eg, basic/molecular/experimental, diagnosis, technology; or reviews without country-specific information. Miscellaneous exclusions were editorials, correspondence or errata concerning included articles; study protocols, and articles on terminology, hypotheses, non-human subjects, or knowledge, attitudes and behaviour relating to $\mathrm{HZ}$ and its treatment.

\section{Literature search results}

The database searches returned 4007 articles (Fig. 1a). Having excluded 1493 duplicates and 1264 non-relevant articles, 1250 were assigned to four categories: epidemiology and burden (421); complications and comorbidities (538); management and prevention (287); and guidelines (4) (Fig. 1b). The separate search for guidelines found recommendations on adult immunisation from Australia, India, Indonesia, Malaysia, New Zealand, the Philippines, South Korea, Taiwan, and Thailand.

'Grey literature' included other key studies/data cited in retrieved articles or not stored in the searched databases, eg, national statistics or reports published locally; 16 such sources were added.

\section{Clinicopathology}

Herpes zoster is caused by reactivation of VZV dormant in nerve root ganglia since a primary varicella infection (Chickenpox). The cardinal symptom is neuropathic pain, often accompanied by a self-limiting vesicular rash 


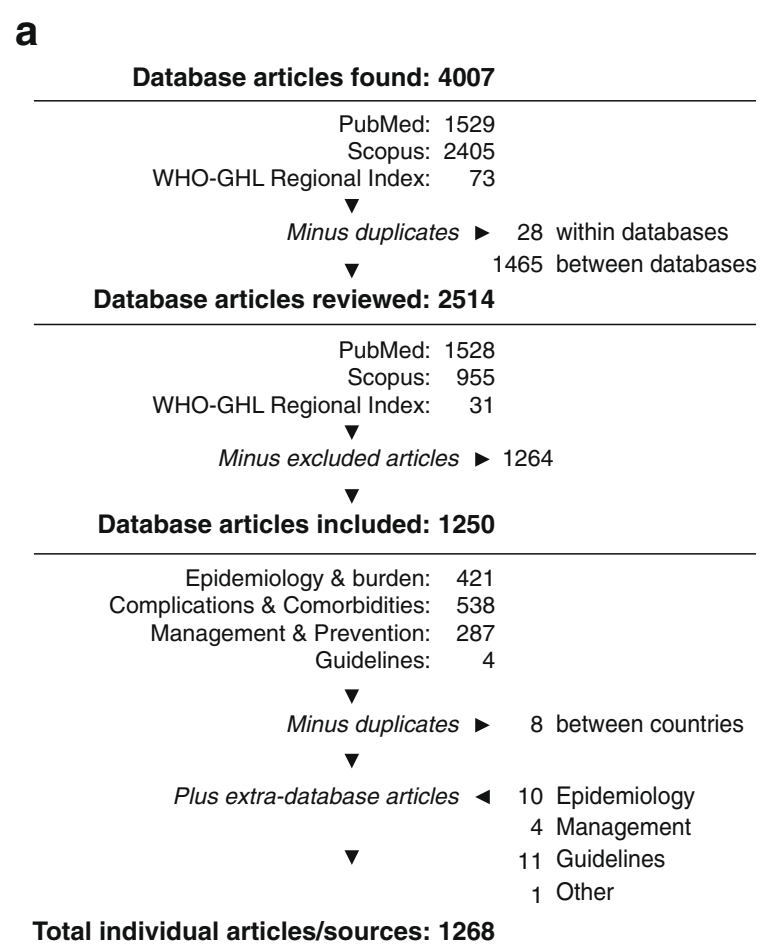

b

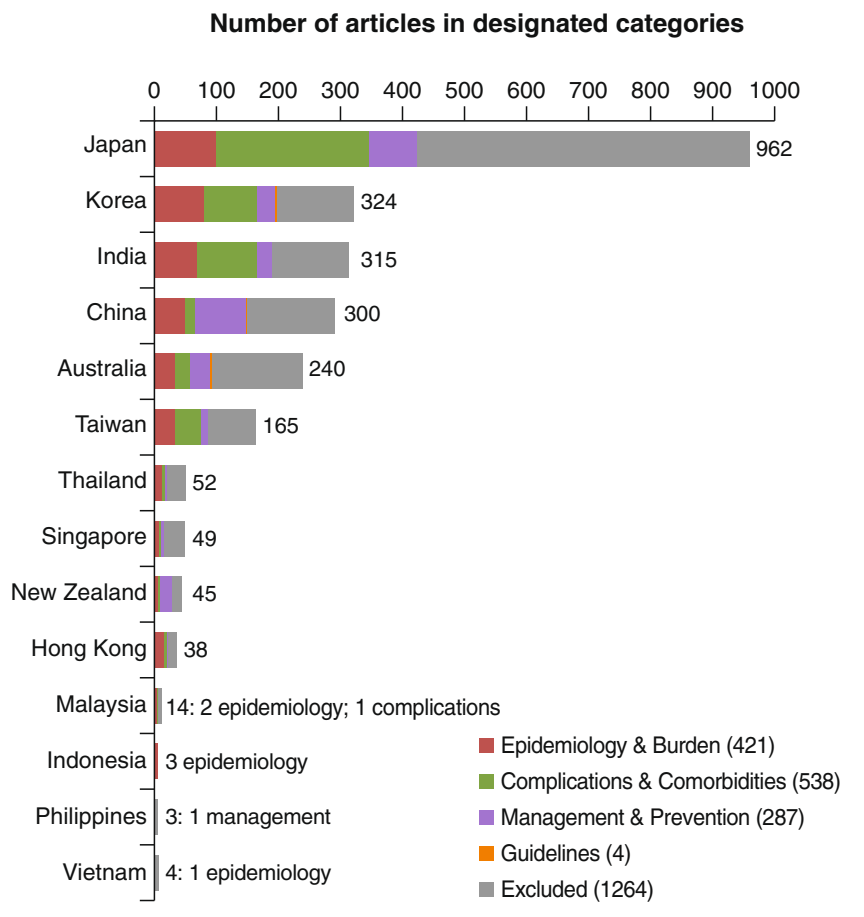

Fig. 1 a Literature search and selection; b) Included articles by country and topic. WHO-GHL, World Health Organization Global Health Library

and/or inflammation disclosing the source nerve [8-10]. In Asia, as elsewhere, the classic presentation is unilateral $\mathrm{HZ}$ affecting a single thoracic dermatome, although $\mathrm{HZ}$ frequently involves the trigeminal, cranial, or cervical nerves; lumbosacral HZ is less common (Fig. 2) [11-31]. The presentations and course of $\mathrm{HZ}$ also vary depending on patients' age, health, and immune status. Older people are more likely to have trigeminal VZV reactivation and worse and longer-lasting rash and pain [20,32], whereas immunocompromised patients tend to have relatively more thoracic HZ [14, 33]. All physicians should therefore beware that $\mathrm{HZ}$ assumes an array of guises.

\section{Atypical $\mathrm{HZ}$}

Reactivated VZV can affect any part of the body. Ocular symptoms due to involvement of the ophthalmic division of the trigeminal nerve are common [34]; however, the maxillary and mandibular branches may occasionally be affected, resulting in oro-cutaneous manifestations [35, 36]. Atypical presentations usually reflect underlying immunocompromise, and other unusual locations have included the eardrum [37], genitalia [38, 39], papilla [40], and finger [41].

\section{Zoster sine herpete}

VZV reactivation does not always manifest cutaneously. Zoster "sine herpete" causes unexplained pathologies, including neuralgia [42], ocular [43], facial [44], or neuromotor palsy or paralysis $[45,46]$, and cerebral or ocular inflammations $[47,48]$.

\section{Multidermatomal, disseminated and visceral $\mathrm{HZ}$}

Rarely, especially in patients who are elderly or otherwise immunocompromised, $\mathrm{HZ}$ involves two or more distinct dermatomes $[49,50]$, spreads across multiple sites [51, 52], appears as a generalised rash [53, 54], or worse, affects internal organs $[9,10]$. Although occasionally seen in immunocompetent individuals [55-64], such unusual presentations constitute fewer than $1 \%$ of total cases, being particularly characteristic of iatrogenic immunosuppression in transplant recipients $[65,66]$ or cancer patients [67-71], or human immunodeficiency virus (HIV) infection, in which bilateral [72, 73], multidermatomal [74], disseminated [75], or recurrent [73, 76, 77] $\mathrm{HZ}$ are often the presenting symptom [72, 78-80].

Disseminated HZ predicts higher risk of complications [81] and may portend abdominal HZ, which has high mortality despite antiviral therapy, especially in profoundly immunocompromised patients $[9,10,82]$. For example, haematopoietic stem cell transplant (HSCT) recipients have died of fulminant VZV hepatitis [83, 84]. Such patients may present with severe abdominal pain [82, 85-87] either sine herpete or before lesions appear $[9,10]$. Besides hepatitis, viscerally disseminated HZ may also cause pancreatitis [88, 89], colitis [90], pneumonitis [91, 92], or pneumonia [69, 93], which causes most fatalities [10]. 


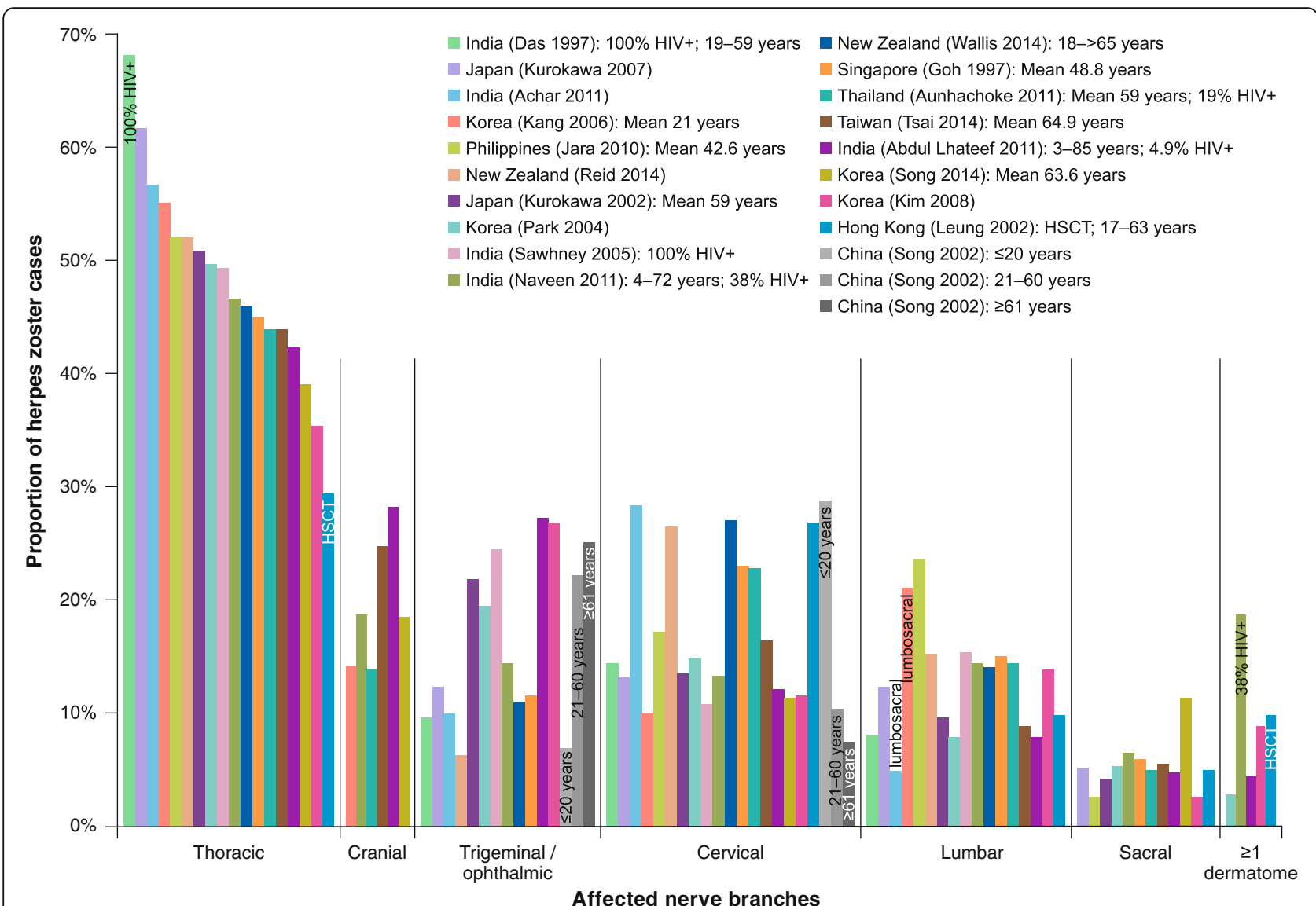

Fig. 2 Nerve branches affected by herpes zoster. HIV+, human immunodeficiency virus positive; HSCT, haematopoietic stem cell transplant

\section{Pain}

Irrespective of its outward appearance, pain is the hallmark of $\mathrm{HZ}$ in adulthood. Acute pain and post-herpetic neuralgia $(\mathrm{PHN})$ are its most unbearable and debilitating symptoms and severely impair QoL and everyday activities $[15,18,20,30]$. Pain is notoriously challenging to manage, especially once established, making this the most compelling reason for early intervention [9, 25, 94, 95].

Almost all adult $\mathrm{HZ}$ patients suffer pain, which can be excruciating and is often described as the worst ever experienced $[10,96]$. Many cases are presaged by prodromal neuralgia or malaise, with abnormal sensations such as itching, paraesthesia and hyperaesthesia $[10,18]$. In India, Korea, Singapore and Taiwan, around two-thirds of patients reported prodromal pain, which more than $90 \%$ rated moderate-to-severe [18, 20, 25, 31]. Among 150 Taiwanese patients, $98 \%$ had acute pain at enrolment (87\% moderate-to-severe) [20]; similarly, 95\% of Indian and Singaporean patients experienced pain during the course of disease $[12,18]$. Pain is more frequent and severe in older patients and can have devastating impacts; patients feel anxious and miserable, have disturbed sleep and cannot work normally or enjoy life $[10,12,15,18,20$,
$25,30]$. Besides age, the severity and duration of acute herpetic pain correlates with the degree of prodromal pain, the severity of skin lesions, trigeminal/ophthalmic involvement, anxiety or depression, and comorbid disease [23, 32, 33, 97-100].

\section{Epidemiology and risk factors Seroepidemiology}

The aetiologic prerequisite of $\mathrm{HZ}$ is prior VZV infection, which most people contract in childhood, unless vaccinated preemptively $[2,7,101,102]$. Although acquisition may be delayed in tropical climes, around $90 \%$ of adults age 30-39 in Asia-Pacific countries/regions have seroconverted, with almost all aged $\geq 40$ years VZV seropositive and therefore at risk of $\mathrm{HZ}$ (Fig. 3) [7, 103-135].

\section{Incidence}

$\mathrm{HZ}$ is very common in the Asia-Pacific region. Alike Western populations, estimated lifetime risk is approximately one-third $[10,136]$, and incidence of 3-10/1000 person-years (PY) rises steeply above age 40 and peaks between 70-80 years (Table 1, Fig. 4); there is female predominance in diverse Asia-Pacific populations, 


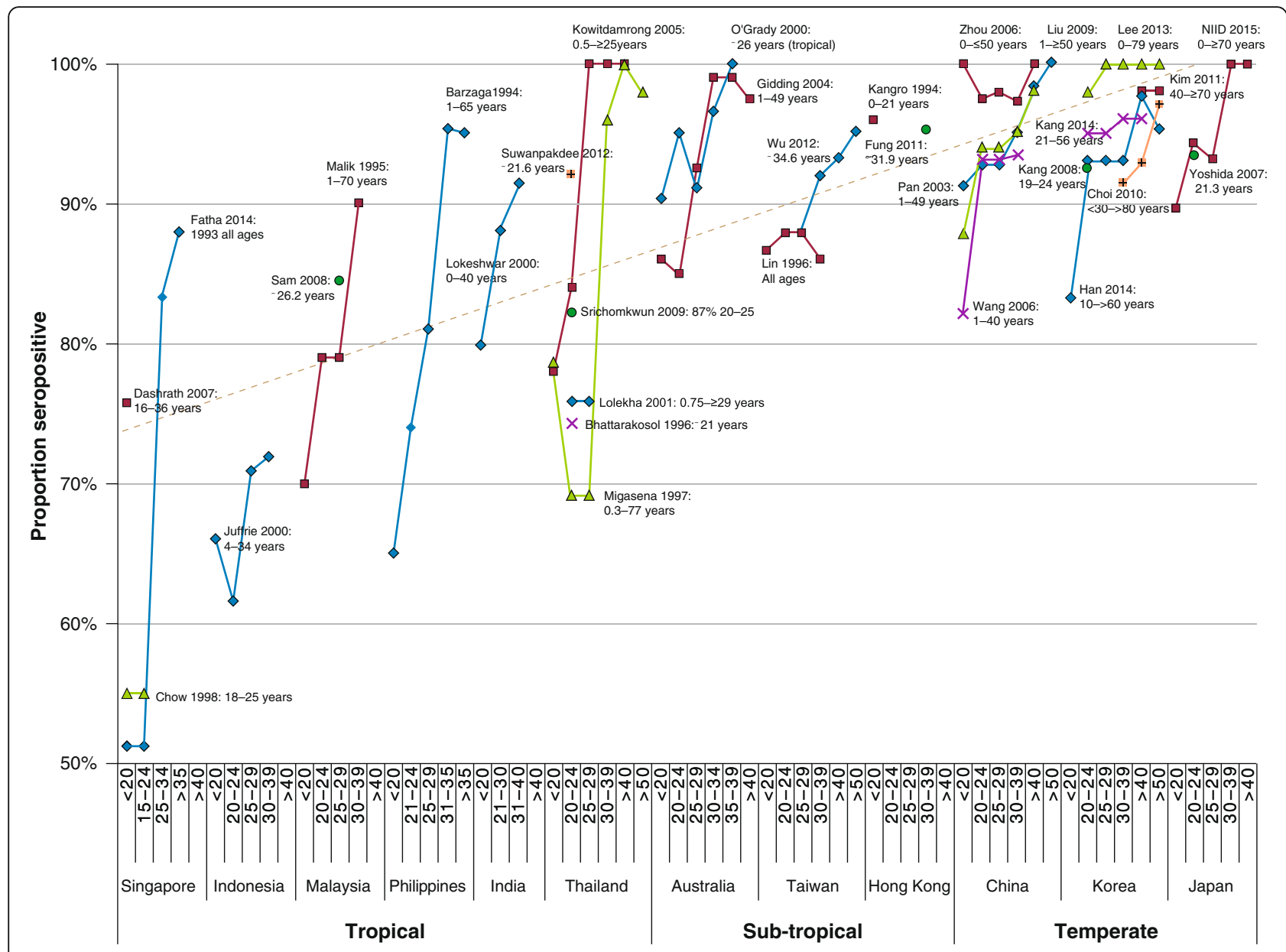

Fig. 3 Ages of varicella zoster virus seroconversion among adults ${ }^{a}$ in tropical, subtropical and temperate Asia-Pacific countries. NIID, National Institute of Infectious Diseases, Japan. ${ }^{a}$ Reported seroprevalence in age-groups including individuals $\geq 18$ years old

especially between ages $50-70[11,17,26,104,126,132$, 133, 136-144]. Authors ascribe higher age-specific incidence rates in Korea than other countries, to heavy use of state-insured healthcare by patients with mild $\mathrm{HZ}$ symptoms, besides being based on data from recent years during which $\mathrm{HZ}$ incidence has risen steeply [138, 140]; on the other hand, much lower incidence in Thailand $[30,144]$ probably reflects under-reporting.

As in other populations, HZ incidence rates are increasing in countries across Asia-Pacific (Table 2, Fig. 5) $[2,102,139-150]$; the principal cause is most likely rising incidence in ageing populations, especially among women, together with growing prevalence of chronic diseases and use of immunosuppressive medications $[2,102$, $139-141,143,147]$. HZ incidence in Taiwan rose by $20 \%$ from 2004-05 to 2006-08 despite remaining stable in 1049 year-olds, with a significant increase in older people [143]. Hypothetically, mass varicella immunisation might also contribute to this trend; if natural exposure to VZV strengthens immunity to $\mathrm{HZ}$ - exogenous boosting - HZ incidence in countries that institute routine childhood varicella immunisation (Table 3 ) would be expected to rise subsequently among the unvaccinated population, due to declining prevalence of varicella [2, 141, 146, 151, 152]. Although there is some evidence that exogenous boosting does occur [151], there is very little for a substantive contribution to $\mathrm{HZ}$, and its role, if any, in $\mathrm{HZ}$ epidemiology remains obscure [2, 141, 143, 146, 147, 151, 152]. Rising HZ rates predating mass varicella immunization (Fig. 5) suggest that other factors are more important; besides those already mentioned, these may also include changes in health-seeking behaviour and more comprehensive and accurate disease surveillance $[151,152]$.

\section{Recurrence}

Reported HZ recurrence rates range from 2.3\% to 8.0\% overall $[13,153,154]$ and are higher in women, immunocompromised patients, and individuals aged 50-70 or with PHN [153]. 


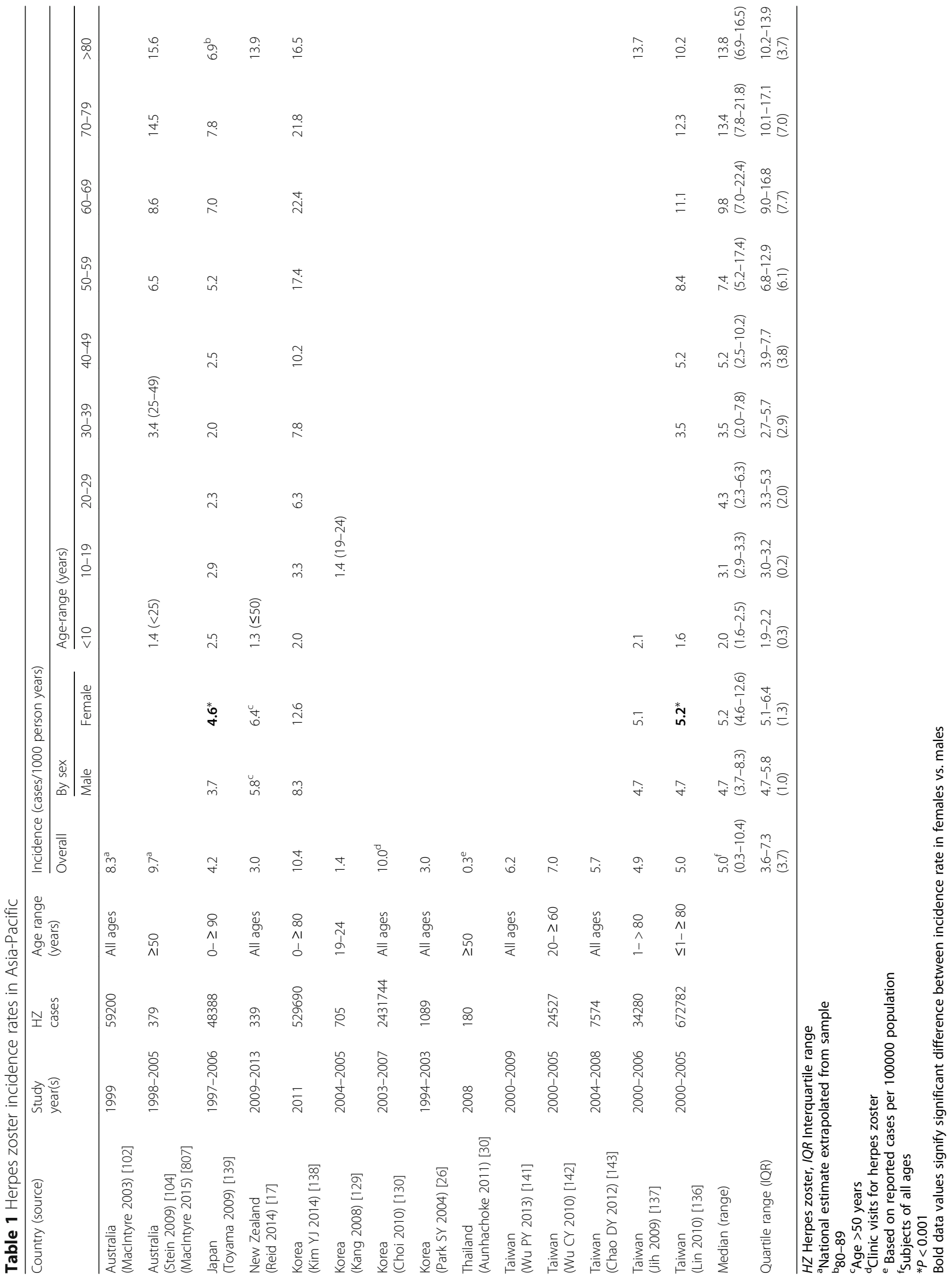




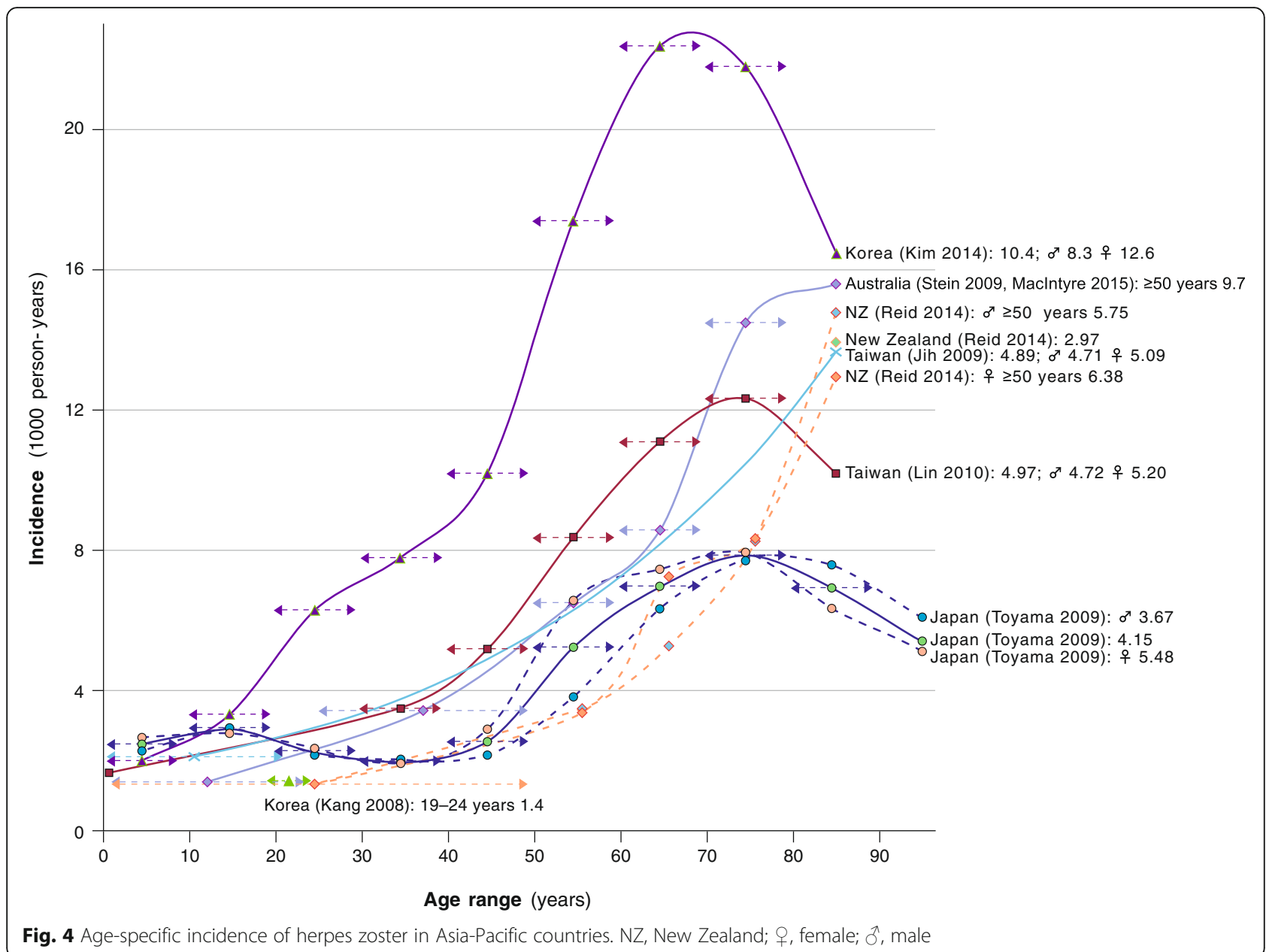

\section{Risk factors and comorbidities}

The constitutional cause of $\mathrm{HZ}$ is failing cell-mediated immunity (CMI) that becomes too weakened to suppress latent VZV [155]. CMI wanes naturally with age [156], explaining why advanced age is the preeminent risk factor for $\mathrm{HZ}$ and $\mathrm{PHN}$ among all populations [10, 95]. Besides immune senescence, other conditions that diminish CMI likewise increase the risk of HZ. The principal predisposing factors are iatrogenic or pathologic immunosuppression (Fig. 6) [137, 157-167]. Inpatients with severe illnesses or recovering from surgery develop $\mathrm{HZ}$ more frequently than others [168].

\section{Immunosuppressant therapies}

Transplantation Organ, tissue or cell transplant recipients require immunosuppressive therapy with cyclosporine and/ or other drugs that prevent transplant rejection. Consequently, they often develop $\mathrm{HZ}$ or other opportunistic infections, especially within the first year following transplantation $[16,66,169-180]$. HZ rates of up to $>80 \%$ have been reported $[170,181]$, and transplant recipients are especially prone to disseminated and visceral $\mathrm{HZ}$ with potentially fatal inflammatory complications [70, 82, 181-186].

\section{Anti-inflammatory and cytotoxic agents}

Corticosteroids Systemic glucocorticosteroids are immunosuppressant and have been associated with $\mathrm{HZ}$ rates above $30 \%$ in long-term use [187-189].

Cyclophosphamide and others Cyclophosphamide-based and other chemotherapeutic regimens substantially increase the risk of $\mathrm{HZ}$ in patients with lymphoma [190-192]. High rates have also been reported in leukaemia patients treated with arsenic trioxide [193-196]. Systemic lupus erythematosus (SLE) and lupus nephritis are also treated with cyclophosphamide, often combined sequentially with azathioprine and prednisolone or mycophenolate mofetil. $\mathrm{HZ}$ is the most common drug-related infection, with rates of up to $40 \%$ [166, 197-201].

$\mathrm{HZ}$ is also an adverse effect of azathioprine and mycophenolate mofetil in SLE and other therapeutic settings 
Table 2 Trends in herpes zoster incidence, hospitalisation and healthcare costs in Asia-Pacific countries

\begin{tabular}{|c|c|c|c|c|}
\hline Country (source) & Metric & Years compared & Herpes zoster rate & Annual increase (\%) \\
\hline Australia (Kelly 2014) [146] & Cases/1000 consultations & $\begin{array}{l}1998 \\
2006-12\end{array}$ & $\begin{array}{l}1.03 \\
1.81\end{array}$ & 6.3 \\
\hline Australia (Nelson 2010) [145] & $\begin{array}{l}\text { Management/1000 GP } \\
\text { consultations }\end{array}$ & $\begin{array}{l}1998 \\
2008\end{array}$ & $\begin{array}{l}1.71 \\
2.35\end{array}$ & 3.4 \\
\hline Australia (MacIntyre 2003) [102] & $\begin{array}{l}\text { Hospitalisations/100000 } \\
\text { population }\end{array}$ & $\begin{array}{l}1993 \\
1998\end{array}$ & $\begin{array}{l}20 \\
25\end{array}$ & 4.2 \\
\hline Australia (Carville 2010) [147] & $\begin{array}{l}\text { Hospitalisations/100000 } \\
\text { population }^{\text {a }}\end{array}$ & $\begin{array}{l}1995-99 \\
2006-07\end{array}$ & $\begin{array}{l}6.3 \\
9.1\end{array}$ & 3.1 \\
\hline Australia (Heywood 2014) [2] & $\begin{array}{l}\text { Hospitalisations/100000 } \\
\text { population }\end{array}$ & $\begin{array}{l}1998 \\
2004 \\
2006-10\end{array}$ & $\begin{array}{l}9.2 \\
10.6 \\
10.4\end{array}$ & $\begin{array}{l}2.2 \\
-0.4\end{array}$ \\
\hline \multirow[t]{3}{*}{ Korea (Choi 2010) [130] } & $\begin{array}{l}\text { Hospitalisations/1000 } \\
\text { population }\end{array}$ & $\begin{array}{l}2003 \\
2007\end{array}$ & $\begin{array}{l}0.22 \\
0.32\end{array}$ & 9.1 \\
\hline & Consultations/1000 population & $\begin{array}{l}2003 \\
2007\end{array}$ & $\begin{array}{l}7.93 \\
12.54\end{array}$ & 11.6 \\
\hline & Total socioeconomic cost (US\$) & $\begin{array}{l}2003 \\
2007\end{array}$ & $\begin{array}{l}75,921,348 \\
143,774,888\end{array}$ & 17.9 \\
\hline Japan (Toyama 2009) [139] & Incidence/1000 person-years & $\begin{array}{l}1997 \\
2006\end{array}$ & $\begin{array}{l}3.61 \\
4.55\end{array}$ & 2.6 \\
\hline Taiwan (Lin 2010) [136] & Healthcare cost (NT\$) & $\begin{array}{l}2000 \\
2004\end{array}$ & $\begin{array}{l}250,000,000 \\
319,000,000\end{array}$ & 5.5 \\
\hline Taiwan (Wu CY 2010) [142] & Incidence/1000 population & $\begin{array}{l}2000 \\
2005\end{array}$ & $\begin{array}{l}4.94 \\
7.00\end{array}$ & 7.0 \\
\hline Taiwan (Chao DY 2012) [143] & Incidence/1000 population & $\begin{array}{l}2000 \\
2008\end{array}$ & $\begin{array}{l}4.45 \\
6.89\end{array}$ & 6.1 \\
\hline Taiwan (Wu PY 2013) [141] & Incidence/1000 person-years & $\begin{array}{l}2000 \\
2009\end{array}$ & $\begin{array}{l}4.40 \\
6.24\end{array}$ & 5.5 \\
\hline Thailand (Bureau of Epidemiology) & $\begin{array}{l}\text { Reported cases/100000 } \\
\text { population }\end{array}$ & $\begin{array}{l}2001 \\
2010 \\
2014\end{array}$ & $\begin{array}{l}6.44 \\
40.49 \\
7.65\end{array}$ & $\begin{array}{l}52.9 \\
-8.1\end{array}$ \\
\hline Median (range) & & & & $5.5(-8.1-17.9)$ \\
\hline Quartile range (IQR) & & & & $3.0-7.5(4.6)$ \\
\hline
\end{tabular}

GP General practitioner, IQR Interquartile range

${ }^{\text {aP }}$ rincipal diagnosis of herpes zoster

[202-214]. Cases of disseminated HZ have occurred in rheumatoid arthritis patients treated with leflunomide, with increased risk in those taking concomitant methotrexate and corticosteroids $[215,216]$. HZ was the most common infection in leflunomide-treated lupus nephritis [217]. The multiple sclerosis drug cladribine is associated with an increased rate of HZ versus placebo [218].

Biologic agents Antibody therapies for cancer, transplant rejection and other conditions are associated with elevated rates of VZV reactivation, both alone and combined with other biologics or chemotherapies. These include alemtuzumab [219], rituximab [220-224], and abatacept [225]. Tofacitinib is associated with significantly higher rates $\mathrm{HZ}$ in Asians than other races [226, 227]. Increased relative risk of $\mathrm{HZ}$ has also been reported with ustekinumab, adalimumab and infliximab [165, 228-230].
Bortezomib Bortezomib directly impairs CMI and is an independent risk factor for $\mathrm{HZ}$ [166], with incidence of up to $40 \%$ in some Asia-Pacific studies [231-250]. HZ prophylaxis is advisable before commencing such therapy [251].

\section{Other iatrogenic risk factors}

Trauma Accidental or iatrogenic trauma can trigger $\mathrm{HZ}$ [252-258]. This is particularly associated with ocular, facial or dental surgeries [259-268], and heightened vigilance is warranted following such procedures, particularly in elderly or immunocompromised patients. Ironically, neurosurgical treatment of PHN occasionally causes HZ [269-271].

Anaesthesia General anaesthesia may compromise immune function, and mothers anaesthetised for 


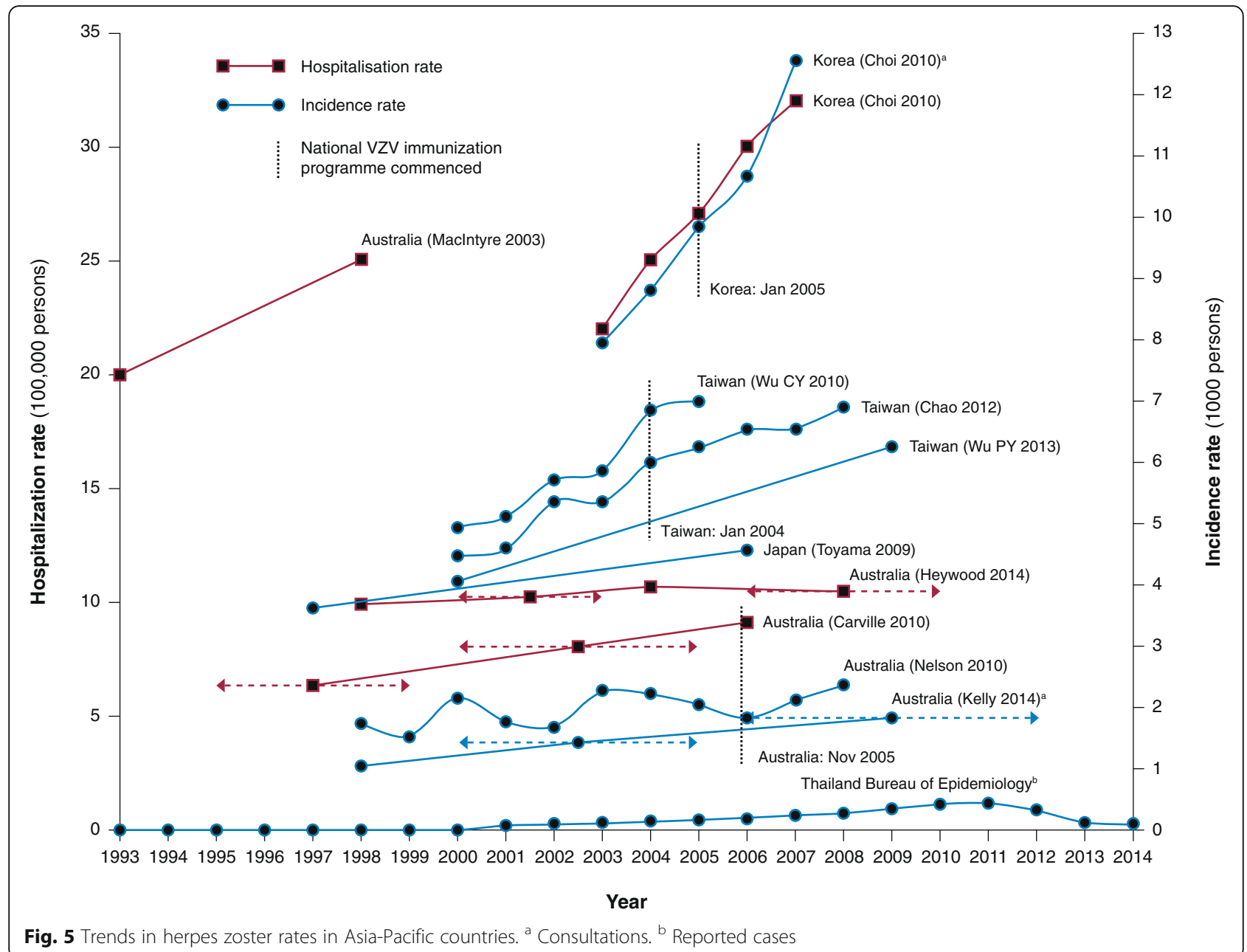

caesarean delivery have a small increased risk of $\mathrm{HZ}$ during the following year [272].

Statin therapy Statin users have slightly increased risk of $\mathrm{HZ}$, likely due to statin-mediated immunosuppression $[273,274]$.
Drug-induced hypersensitivity syndrome Drug-induced hypersensitivity is a severe reaction to certain drugs that involves the reactivation of herpes viruses, including VZV. Systemic corticosteroids may contribute to this risk, and like immune restoration syndrome, withdrawal of corticosteroid may trigger HZ [275].

Table 3 Asia-Pacific countries with national varicella immunisation programmes

\begin{tabular}{|c|c|c|c|c|}
\hline \multirow[t]{2}{*}{ Country } & \multicolumn{2}{|c|}{ Varicella vaccine schedule } & \multirow[t]{2}{*}{ Planned extent of coverage } & \multirow{2}{*}{$\begin{array}{l}\text { Programme } \\
\text { commenced } \\
\text { (month, year) }\end{array}$} \\
\hline & Dose(s) & Age & & \\
\hline Australia & 1 & 18 months, with catch-up at 10-13 years ${ }^{\mathrm{a}}$ & Entire population & November 2005 \\
\hline Hong Kong & 2 & 12 months \& 6 years ${ }^{b}$ & Entire population & November 2005 \\
\hline Japan & 2 & $12-36$ months & Entire population (voluntary category) ${ }^{c}$ & October 2014 \\
\hline New Zealand & 1 & 15 months, with catch-up at 11 years ${ }^{d}$ & Entire population & July 2017 \\
\hline South Korea & 1 & $12-15$ months & Entire population & January 2005 \\
\hline Taiwan & 1 & $12-18$ months & Entire population & January 2004 \\
\hline
\end{tabular}

${ }^{\text {a Schools programme }}$

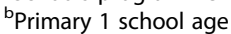

${ }^{c}$ Not covered under the Preventive Vaccinations Act for Routine Vaccination against Category A Diseases

${ }^{\mathrm{d}}$ For non-vaccinated children who have not already had a varicella infection 


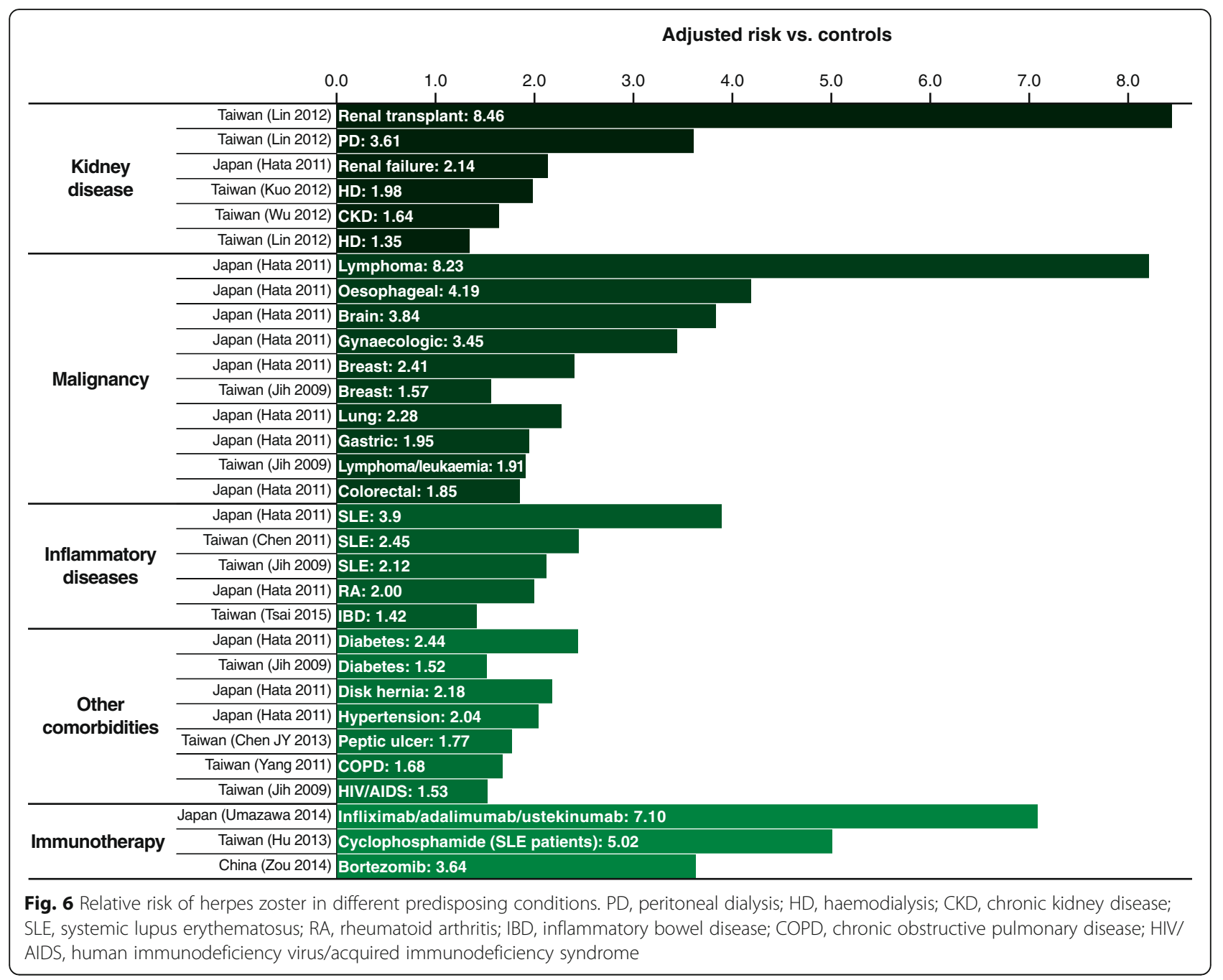

\section{Infections}

HIV/AIDS HIV/Acquired Immunodeficiency Syndrome (AIDS) is a major healthcare problem in Asia. With prevalence of up to $30 \%$ and incidence as high as $40-50$ / 1000 PY [276-303], HZ is so common in HIV-infected individuals that it may be a pragmatic prognostic marker [14, $27,28,76]$, especially among younger individuals [304309]. AIDS patients may have recurrent [73, 76, 77, 80], disseminated [27, 78], or cerebral HZ infections [310, 311]. $\mathrm{HZ}$ incidence correlates with low CD4+ cell count [310, 312-314] and may be significantly reduced by highly-active antiretroviral therapy (HAART); however rates in the postHAART era remain double-digit $[281,303]$.

Immune reconstitution syndrome Paradoxically, patients regaining immunocompetence following HAART are at higher risk of $\mathrm{HZ}$ than when immunodeficient, probably due to increasing CD8 cell count, a phenomenon termed immune reconstitution inflammatory syndrome [315-318].
Varicella zoster virus Counterintuitively, Taiwanese healthcare workers frequently exposed to VZV did not gain enhanced immunological protection, and had higher incidence of $\mathrm{HZ}$ than the general population; however, this may be because their very stressful working environment dampened CMI, overriding any protective effect [142]. Epidemiology data from Japan [319] and elsewhere suggests that varicella exposure boosts immunity to $\operatorname{HZ}[102,151]$. Nevertheless, rare localised HZ clusters suggest that VZV re-exposure might occasionally provoke recrudescent $\mathrm{HZ}$; the mechanism is unknown, but may involve disruption of CMI by the humoral response to VZV reinfection [320]. Although VZV transmission from patients with $\mathrm{HZ}$ is rare, due to less and more localised viremia, exudate from open $\mathrm{HZ}$ lesions may potentially infect close contacts who have not had varicella or been immunised [10, 320-324].

Other pathogens Rare cases of $\mathrm{HZ}$ associated with tuberculosis or malaria have been reported in China and India [325-328]. 
Table 4 Common comorbidities of herpes zoster in Asia-Pacific patient populations

\begin{tabular}{|c|c|c|c|c|c|c|c|c|}
\hline \multirow[t]{2}{*}{ Country (source) } & \multirow{2}{*}{$\begin{array}{l}\text { Setting } \\
\text { (patient number) }\end{array}$} & \multirow{2}{*}{$\begin{array}{l}\text { Age profile } \\
\text { (years) }\end{array}$} & \multicolumn{6}{|c|}{ Proportions with comorbidities (\%) } \\
\hline & & & Any & Hypertension & Diabetes & Malignancy & Pulmonary & Cardiovascular \\
\hline Korea (Park SY 2004) [26] & Dermatology (1089) & NA & 36.5 & 12.6 & 7.9 & 0.6 & $1.7^{\mathrm{a}}$ & $1.6^{c}$ \\
\hline Korea (Kim YM 2008) [11] & Dermatology (297) & NA & 56.2 & 32.1 & 17.5 & 10.4 & $7.5^{\mathrm{a}}$ & NA \\
\hline China (Yuan LL 2014) [339] & Hospitals (2960) & Median 60 & & 22.2 & 11.7 & & $6.2^{\mathrm{b}}$ & 10.7 \\
\hline Philippines (Jara 2010) [15] & Hospital (221) & Mean 43 & 28.0 & 13.6 & & 1.8 & 8.1 & 2.7 \\
\hline Japan (Kurokawa 2002) [23] & Hospitals (263) & Mean 59 & 41.1 & & 9.6 & 13.7 & & \\
\hline $\begin{array}{l}\text { Thailand (Tunsuriyawong 2005) } \\
\text { [154] }\end{array}$ & Hospital (339) & Mean 59 & 26.8 & 4.0 & 2.5 & 1.0 & & \\
\hline India (Abdul Latheef 2011) [12] & Hospital (205) & $47 \%>40$ & 14.6 & & 5.3 & 9.2 & & \\
\hline Taiwan (Jih 2009) [137] & National (34380) & $33 \%>60$ & & & 20.6 & 2.7 & & \\
\hline Taiwan (Hu 2013) [166] & Hospital (2306) & & 24.3 & & & 14.8 & & \\
\hline Taiwan (Wu CY 2010) [142] & National (702932) & & & & & 1.0 & & \\
\hline \multirow[t]{3}{*}{ Japan (Kurokawa 2007) [28] } & Dermatology (316) & & 42.1 & 4.1 & 6.6 & 15.2 & & \\
\hline & & $\begin{array}{l}\text { Median } \\
\text { (range) }\end{array}$ & $\begin{array}{l}32.3 \\
(14.6-56.2\end{array}$ & $\begin{array}{l}13.1 \\
(4.0-32.1\end{array}$ & $\begin{array}{l}8.8 \\
(2.5-20.6)\end{array}$ & $\begin{array}{l}6.0 \\
(0.6-14.8)\end{array}$ & $\begin{array}{l}6.9 \\
(1.7-8.1)\end{array}$ & $\begin{array}{l}2.7 \\
(1.6-10.7)\end{array}$ \\
\hline & & $\begin{array}{l}\text { Quartile range } \\
(\mathrm{IQR})\end{array}$ & $\begin{array}{l}26.2-41.4 \\
(15.2)\end{array}$ & $\begin{array}{l}6.2-20.1 \\
(13.8)\end{array}$ & $\begin{array}{l}6.3-13.2 \\
(6.9)\end{array}$ & $\begin{array}{l}1.2-12.9 \\
(11.7)\end{array}$ & $\begin{array}{l}5.1-7.7 \\
(2.6)\end{array}$ & $\begin{array}{l}2.2-6.7 \\
(4.6)\end{array}$ \\
\hline
\end{tabular}

NA Data not available, IQR Interquartile range

${ }^{\mathrm{a}}$ Asthma

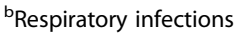

${ }^{c}$ Angina pectoris

\section{Intrinsic risk factors}

Pregnancy Pregnancy is another immunosuppressed state that may potentiate HZ [120]. Although this seldom occurs, $\mathrm{HZ}$ is the most common skin infection that dermatologists encounter in pregnant women, accounting for up to $30 \%$ of cases [329]. While challenging to treat, unlike congenital varicella, $\mathrm{HZ}$ poses minimal risk to the foetus [330, 331].

Good's syndrome Good's syndrome is a very rare immunodeficiency disease predisposing to $\mathrm{HZ}$ [332].

Nutritional deficiency Micronutrient deficiencies that diminish CMI may increase susceptibility to $\mathrm{HZ}$ and PHN; supplements, particularly vitamin $\mathrm{D}$, can boost VZV immunity [333-335].

Genetic predisposition Asians have genetic predispositions to HZ; specifically, human leukocyte antigen gene polymorphisms have been linked to VZV reactivation in East Asian populations [336-338].

\section{Associated diseases}

Unsurprisingly, many $\mathrm{HZ}$ patients have common diseases of older age (Table 4), most frequently hypertension, diabetes, malignancies, and pulmonary disorders $[11,12,15,23,26,28,137,154,166,339]$; however, since comorbidities and/or complications account for high proportion of hospitalised $\mathrm{HZ}$ cases $[11,12,15,23,26,28$,
$102,104,136,137,154,166,340]$, these may be more prevalent among such patients than in the general population.

Patients with certain underlying diseases have apparently increased risk of $\mathrm{HZ}$; however, it may be difficult to ascertain whether such relationships are causal, reflect underlying pathology, or are coincidental. In cancer, SLE, and other diseases treated with immunosuppressants, $\mathrm{HZ}$ may be largely treatment-related, although the disease too may make an indeterminate contribution to increasing the risk [10]. In others, for example, diabetes and renal disease, impaired CMI may be a common factor. Adjusted for age and other confounding variables, several comorbidities have been identified as independent risk factors for $\mathrm{HZ}$, most notably renal disease, malignancies, and SLE (Fig. 6) [137, 157-167].

Renal disease The incidence of $\mathrm{HZ}$ increases across the spectrum of renal disease, with transplant patients at highest risk followed by peritoneal dialysis and haemodialysis [157, 159, 160, 341-343]. The risk of $\mathrm{HZ}$ in haemodialysis is heightened by corticosteroid use, but may be mitigated by iron and vitamin $\mathrm{D}$ supplementation [334, 335].

Inflammatory autoimmune diseases $\mathrm{HZ}$ frequently afflicts patients with connective tissue disorders [344], with double the risk in rheumatoid arthritis [158]. Patients with SLE have impaired CMI and are treated 


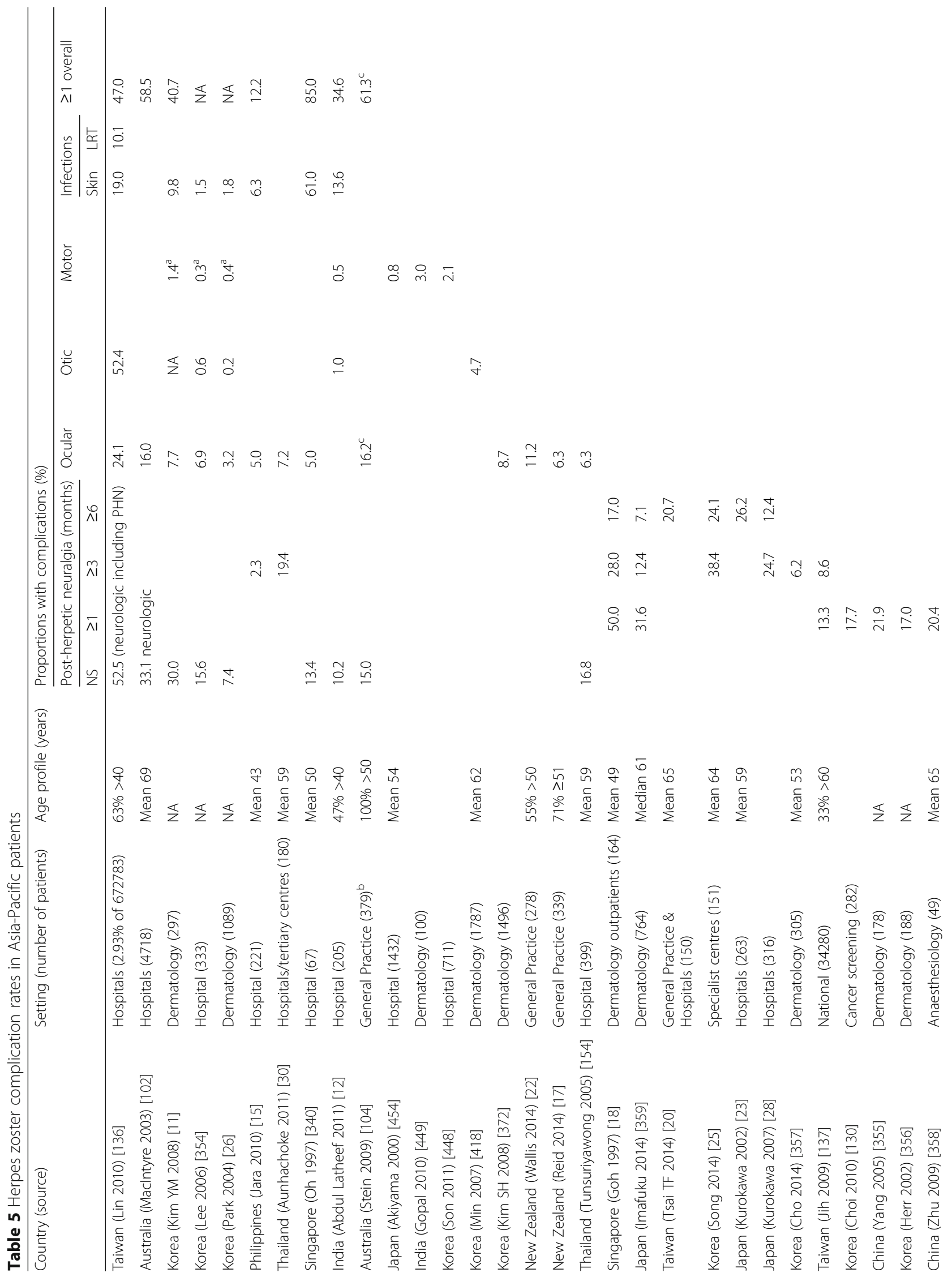




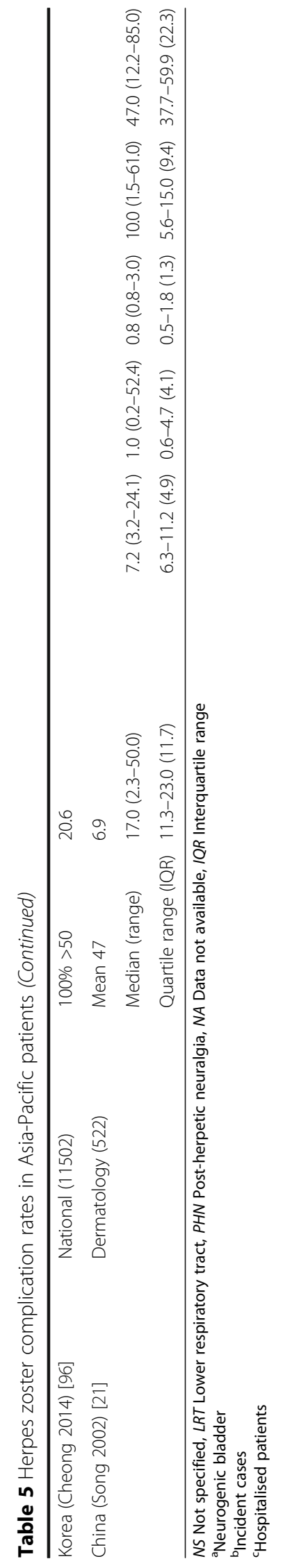


with immunosuppressant anti-inflammatory drugs, which significantly increases their risk of $\mathrm{HZ}[137,161,345,346]$, particularly if they have neuropsychiatric manifestations, renal involvement, or receive cyclophosphamide [166]. Likewise, increased risk of $\mathrm{HZ}$ associated with inflammatory bowel disease probably reflects iatrogenic immunosuppression in many patients [162, 347].

Cancer Cancer patients may be immunosuppressed due to malignancy, its treatment, or both [12, 39, 348]. Risk of $\mathrm{HZ}$ is increased in both solid and haematologic cancers $[158,349,350]$, especially leukaemia and lymphoma $[137,158]$.

Pulmonary disease Both immune dysregulation and corticosteroid therapy may account for increased risk of HZ in chronic obstructive pulmonary disease. Patients taking oral corticosteroids are at the greatest risk [164].

Diabetes Patients with diabetes have impaired VZVspecific CMI [351]; however, evidence that diabetes is a risk factor for $\mathrm{HZ}[137,158,352]$ is inconclusive.

Peptic ulcer disease Peptic ulcer disease independently predicts HZ, having excluded confounding effects of anti-inflammatory drugs and Helicobacter pylori infection [163].

Psychiatric disorders CMI is also diminished in psychiatric disorders. The risk of $\mathrm{HZ}$ is increased in patients with affective psychoses, neurotic illness, personality disorders and other mental disorders, especially among those younger than 60 [353].

\section{Complicating presentations and disease associations}

\section{Post-herpetic neuralgia}

The most common complication of HZ in adults everywhere is pain outlasting the eruptive phase [94]. Definitions of PHN are inconsistent, ranging from $\geq 1$ to $\geq 6$ months since rash onset; however, PHN may persist for years [10]. Reported rates vary widely, depending on patients' age profiles and the definitions used [20]; nonetheless, the incidence generally ranges between $\leq 10$ to $\geq 25 \%$, with up to $20 \%$ still enduring pain after 6 months (Table 5) $[11,12,15,18,20,21,23,25,26,28,30,96,104$, $130,137,154,340,354-359]$. PHN correlates strongly with advancing age $[15,18,21,96,102,137,340$, $356,357]$, the other major prognostic factors being the severity of $\mathrm{HZ}$ and intensity of acute pain [23, 99, 137, 356, 357, 360-362]. Comorbid risk factors include diabetes, lymphoma/leukaemia, SLE [137, 363], peptic ulcer disease [364], and micro-nutrient deficiencies [333]. There is also evidence of specific phenotypic [358] and genotypic predispositions [365-368]. Bortezomib may aggravate PHN independently of VZV reactivation [369].

Neuropathy, inflammation and secondary complications HZ causes multifarious complications, especially inflammatory sequelae, which affect up to half or more of hospitalised HZ patients. The most common besides PHN involve the skin, eyes or, less often, ear, nose and throat (Table 5) [11, 12, 15, 26, 30, 102, 104, 136, 340, 354]. Uncommon complications include muscular weakness or paralysis and serious - sometimes life-threatening cerebral or visceral inflammation. Elderly or immunocompromised individuals are more frequently and often worse affected [30, 96, 340, 370].

\section{Eye}

The most common and severe complications stem from VZV reactivation in trigeminal ganglion, which is the most frequently affected non-spinal location [11, 12, 23, 26, 29, 34, 371]. In particular, HZ ophthalmicus (HZO) arising from the ophthalmic division accounts for $5 \%$ to $25 \%$ of $\mathrm{HZ}$ cases in Asia-Pacific countries [11, 15, 17, 22, $30,102,104,136,154,340,354]$ (Table 5 ). The majority of cases, especially those accompanied by nose eruptions (Hutchinson's sign) [372-375], are complicated by secondary inflammation such as conjunctivitis, keratitis [376-378], scleritis, and uveitis/iridocyclitis [372-374, 379-381]. Such complications can cause glaucoma and are potentially blinding, especially if not treated promptly [379, 382]. However, inflammatory sequelae may not manifest until some time after an $\mathrm{HZ}$ episode [383]. Early and intensive antiviral therapy is particularly important for patients with HIV/AIDS, who tend to have worse and treatment-refractory inflammation, with resultant vision loss [384-386].

Molecular diagnostic techniques have revealed VZV reactivation to be a predominant cause of anterior uveitis in South and East Asian countries [387-389], with significantly increased risk within 1 year following $\mathrm{HZ}$, especially HZO [390]. VZV is also a major cause of acute retinal necrosis [391-397] in the region, and of progressive outer retinal necrosis, which is usually seen in severely immunocompromised patients [398-402]. Both conditions have particularly poor visual outcomes, even when treated appropriately $[375,391,392,397$, 399, 403-407].

Less common ocular complications include, corneal endotheliitis [408], retinochoroiditis [381], optic neuritis [409-411], oculomotor palsy [371], dacryoadenitis [412, 413], superior orbital fissure syndrome [414], orbital apex syndrome $[415,416]$, and central retinal vein occlusion [417]. 


\section{Ear, nose and throat}

Occasionally, VZV reactivation in the facial nerve genicular ganglion causes $\mathrm{HZ}$ oticus (Ramsay Hunt syndrome) $[418,419]$. Patients often have multiple neuropathies and diverse symptoms, depending on the cranial and facial nerve branches involved. As elsewhere, the characteristic triad is facial palsy, auricular rash and ear pain [418, 420422]; however, some cases affect the tongue, soft palate, or throat $[423,424]$, and the rash may precede facial paralysis, not appear until afterwards [420], or be absent [424]. Many patients experience hearing loss and vestibulocochlear symptoms such as tinnitus and vertigo [418, 420, $425,426]$. The seventh and eighth cranial nerves are most commonly affected [420, 427], but many atypical cranial neuropathies have also been identified [428-431]; Ramsay Hunt syndrome has been associated with dysphonia [46, 424, 429, 432, 433], laryngitis [434, 435], loss of taste [436], chronic cough [437], hiccups [435, 438], dysphagia [46, 424, 429, 439], and persistent vomiting [438]. Other rare complications include jugular foramen syndrome [440] and non-facial neuromotor deficits [441]. In addition to Ramsay Hunt syndrome, zoster sine herpete is increasingly recognised as a major aetiologic factor in idiopathic Bell's palsy [442-444] and Ménière's disease [445, 446].

$\mathrm{HZ}$ oticus generally responds to prompt antiviral therapy, with good outcomes [421, 430]; however, half of patients may not recover fully from facial palsy [420, 421], with even lower rates among those who are older [427], have multiple cranial neuropathies [420], or are not treated [419]. The diversity of manifestations, often occurring sine herpete, creates potential for misdiagnosis [419]. It is vital for clinicians to remain alert to the possibility of $\mathrm{HZ}$, so that treatment can begin early enough to avoid potentially life-threatening sequelae of VZV reactivation in the head and/or neck [438, 447].

\section{Neuromuscular}

Fewer than $5 \%$ of $\mathrm{HZ}$ cases in Asian patients cause motor neuropathy [448-450]. Though more common in the elderly or immunocompromised [450, 451], such complications also affect immunocompetent individuals [452, 453]. Among 711 Korean HZ patients, 2.1\% had neuromotor weakness, predominantly affecting cranial rather than spinal nerves [448]. The incidence was $0.8 \%$ among 1432 Japanese patients [454] and 3\% in an Indian cohort [449]. Such complications may arise before skin lesions appear and are likely underdiagnosed because they are masked by overriding pain $[455,456]$; they may also occur some time after $\mathrm{HZ}$ onset [452, 457, 458]. Other presentations include gastrointestinal or bladder dysfunction [10], myelitis [450, 459-461], and myositis [462]. VZV infection is implicated in the aetiology of Guillain-Barré syndrome [463-465].
Face and eye VZV reactivation is a common cause of Bell's palsy [466]. HZO may present as orbital myositis preceding skin eruptions [462], and sometimes causes complete ophthalmoplegia [467-472].

Limbs Paresis of the ipsilateral shoulder or arm [473477], occurs in $3-5 \%$ of $\mathrm{HZ}$ cases, but is underdiagnosed [478, 479]. Some cases are due to brachial plexopathy $[480,481]$, and others to Brown-Séquard hemiplegia [460, 482]. Lower limb neuropathy may manifest as foot drop [449, 483], and HZ paresisinduced femoral fracture has been reported [484].

Trunk and abdomen Cervical myelitis can cause diaphragmatic paralysis with resultant dyspnoea [457, 485487]. Segmental paresis may cause abdominal protrusion or pseudohernia [488-492], which are associated with gastrointestinal complications, notably constipation due to intestinal pseudo-obstruction or colonic ileus [488, 493496].

Lumbosacral Voiding dysfunction associated with sacral $\mathrm{HZ}$ is uncommon but not rare, especially among immunocompromised patients [497]. The incidence among 423 Taiwanese HZ patients was $4 \%$ overall, and $29 \%$ among those with lumbosacral HZ [498]. Urinary problems include neuropathic bladder [499], loss of voiding sensation [500] and occasional acute urinary retention [461, 501-503]. Other complications include faecal incontinence [504] rectal ulcer [505] and sciatica [506].

\section{Vasculopathy}

Though rare, vasculitic cerebral inflammation is the most serious neurologic complication of $\mathrm{HZ}$; VZV from intracranial branches of the trigeminal nerve that invades and inflames the carotid artery or its branches, may cause fatal strokes $[9,10]$.

Cerebrovascular Cerebral arteritis arising from HZ, especially HZO, significantly increases the risk of thromboembolic or haemorrhagic strokes [507, 508]. Those affected may have no visible lesions $[509,510]$ and strokes may be delayed [511-516] or occur without characteristic risk factors or symptoms [512, 513, 517, 518], leading HZ-associated stroke to be underdiagnosed [514, 519]. HIV/AIDS might be suspected in otherwise healthy younger individuals $[518,520]$.

Cerebral inflammation Rare but severe and sometimes fatal neurologic complications include meningitis or meningo-encephalitis [521-526], cerebellitis [527], and encephalitis $[528,529]$. Other reports include posterior reversible encephalopathy syndrome [530], CLIPPERS syndrome [531], and fatal meningo-encephalomyelitis [532]. 
Again, those affected are generally immunocompromised $[9,10]$, although accruing evidence suggests that such complications affect young and/or immunocompetent individuals more often than was supposed [521, 533-538].

Ocular Cases of Horner's syndrome and related cranial nerve palsies [539-542] have been attributed to HZOinduced arteritis and VZV meningitis [543]. Reported $\mathrm{HZ}$ retinopathies include visual loss due to central retinal artery occlusion and vasculitic chorioretinopathy $[404,544,545]$.

Cardiovascular Intriguing evidence hints at a link between $\mathrm{HZ}$ and cardiovascular disease in Asia. There are modestly elevated risks of acute coronary syndrome, arrhythmia and coronary artery disease following $\mathrm{HZ}$ $[546,547]$. Herpetic infections may also be associated with atherosclerosis and thrombosis [546], with reports of HZ-associated deep vein thrombosis [548] and peripheral vascular disease [525]. Myocarditis [549] and unexplained recurrent asystole [550] following $\mathrm{HZ}$ have also been reported. Interestingly, however, Japanese patients with prior HZ had lower blood pressure than those with no history [551].

\section{Skin}

The most common dermatologic complications are secondary infections but numerous others have been described [9]. Rare complications include folliculitis, syringitis, and vasculitis [552-554]. HZ can also cause hair loss [555, 556].

Infections Secondary infections complicate up to $30 \%$ of $\mathrm{HZ}$ cases [136], rising to $60 \%$ in vulnerable hospitalised patients [340]. The most common are staphylococcus or streptococcus superinfections $[9,10]$. Other opportunistic organisms include moraxella [557], and aspergillus [558]. Bacterial infections are more likely in patients with diabetes $[559,560]$ and potentially serious, with necrotising fasciitis reported in one immunocompromised patient [561]. Immunocompromised patients, particularly those with HIV/AIDS, may rarely become reinfected by varicella despite a history of HZ [562].

Isotopic responses $\mathrm{HZ}$ may render affected skin susceptible to other infections or dermatoses, for example, moloscum contagiosum, mycosis fungoides [154], erythema multiforme [563], and psoriasis [564, 565]. Diverse 'isotopic' responses at healed $\mathrm{HZ}$ sites include: vitiligo [566], fungal granuloma [567], furuncles [568], granulomatous reactions [569-574], erythemas [575-578], lichen planus [579, 580], morphea and bullae [581-583], perforating collagenosis [584, 585], keratolysis [586] and sarcoidosis [587, 588], reticulohystiocytosis [589], nodular degeneration [590, 591], verrucous hyperplasia [592], mucinosis [593], urticaria [594], prurigo nodularis [595], graft-versus-host reaction [596], drug-induced eruption [597], adenocarcinoma [598], leukaemia cutis [599], Kaposi's sarcoma [600], and tufted angioma [601].

\section{Dental}

Jaw osteonecrosis and tooth loss are rare complications of trigeminal HZ. Cases have been reported in both immunocompetent and immunocompromised Asians; the mechanism remains unknown [602-610].

\section{Disease associations}

Emerging evidence from Taiwan and Japan suggests that patients with $\mathrm{HZ}$ are at increased subsequent risk of cardiovascular disease [546, 547], lymphoma [611] and other cancers [466, 612, 613], renal failure [614], SLE [615], multiple sclerosis [616], chronic fatigue syndrome [617], depression [618, 619] and erectile dysfunction [620]; however, the causality and significance of these associations remains unclear. Prevalent comorbidities such as metabolic syndrome disorders probably contribute to cardiovascular risk [547], while immunosuppression may underlie other conditions. Like HZ, kidney disease [160, 335], cancer [466, 612, 621, 622], and depression [158] are also associated with immunosuppression, and HZ may occur coincidentally either before or after these conditions manifest.

Anecdotal reports implicate VZV reactivation in rare conditions such as inappropriate secretion of antidiuretic hormone [85, 87, 623-626], drug-induced hypersensitivity syndrome [627], mononucleosis syndrome [628], thrombocytopenia [629], and graft-versus-host disease [630].

\section{Healthcare utilisation}

As in the West, HZ-associated pain, morbidity and debility, result in heavy healthcare utilisation, especially among elderly patients, which imposes major burdens on healthcare systems and incurs substantial socioeconomic costs in Asia-Pacific countries [20, 25, 30, 96, $102,104,136,137,140]$. Although uncomplicated cases can usually be treated in community or outpatient settings, this usually entails several visits [20, 30, 96, 102]; Korean $\mathrm{HZ}$ patients averaged seven visits to a primary physician [96], and among 150 elderly Taiwanese patients, more than $80 \%$ consulted a doctor, with $20 \%$ hospitalised [20].

\section{Hospitalisation}

Throughout Asia-Pacific, HZ is consistently among the disorders that dermatologists or pain specialists treat most often, and is the most common dermatosis in patients aged 60-70 years [149, 631-641]. Hospitalisation 
rates for $\mathrm{HZ}$ range from $~ 9-51 / 100000$ PY (Table 6) [2, 7, 102, 104, 136-138, 140, 147]; complications account for around half of admissions (Table 5) [102, 104, 136] and, therefore, hospitalisation rates likewise increase with age and are highest among elderly or immunocompromised patients [96, 102, 104, 136, 138, 140, $147,642]$. Older patients and those with complications stay longer in hospital $[136,137]$.

\section{Healthcare expenditure}

Accordingly, HZ-related healthcare costs also increase proportionally with patients' age and parallel rising incidence $[136,137]$. Total expenditure in Taiwan rose by 1.22-fold from US\$7.7 million in 2000 to \$US 9.8 million in 2004 [136], and in Korea by $20 \%$ between 2003 and 2007 (Table 6) [140]. Direct healthcare costs in Thailand are equivalent to $1.1 \%$ of annual per capita income, a similar ratio to that in developed nations [30].

$\mathrm{HZ}$ in the Asia-Pacific region evidently imposes very substantial burdens on both patients and the wider community, strongly supporting the case for early intervention and prevention to reduce both HZ-related morbidity and associated healthcare expenditure [20, 25, 30, 96, 102, 104, 140].

\section{Management and prevention}

Routine HZ management in Asia-Pacific is the same as elsewhere, mainly relying on antiviral and analgesic drugs to reduce the severity and duration of acute herpetic rash and pain, which may in turn decrease the risk and intensity of PHN $[643,644]$.

\section{Antiviral therapies}

Standard care entails aciclovir, valaciclovir, or famciclovir for 7 days [643]. These are most effective if commenced within 3 days of onset [645] but as starting later may still be beneficial, patients with HZO, who are immunocompromised, have disseminated $\mathrm{HZ}$, or are at high risk for PHN, should start antiviral therapy even beyond 72 hours [643-646]. Topical or oral aciclovir are effective in most mild-moderate $\mathrm{HZ}$, including $\mathrm{HZO}$ [647-651]; nevertheless aciclovir is least favoured nowadays because its lower bioavailability necessitates more frequent dosing $[9,644,652]$. Though comparative data are sparse [643, 652], Asian studies support the use of other antivirals.

A meta-analysis including data from Taiwan $[653,654]$ and China, found valaciclovir and famciclovir superior to aciclovir in reducing HZ-associated pain, with comparable safety [652]. Valaciclovir resolves pain significantly faster than aciclovir [31, 653-655], while famciclovir has comparable efficacy but fewer adverse effects, and may also be more cost-effective [656, 657]. Penciclovir is also effective at lower doses than aciclovir, with better safety [658]. Specifically, aciclovir or its prodrug valaciclovir have been associated with neurotoxicity, and nephrotoxicity in East Asian patients with renal impairment [659-669], whereas famciclovir was safe and effective in patients with renal dysfunction [670, 671]. Treating HZ keratopathy with aciclovir ointment has been reported to cause superficial punctate keratopathy [672]. Ganciclovir may be a more effective alternative [673, 674], especially in aciclovirresistant acute retinal necrosis [675]; success with intravitreal foscarnet following acyclovir failure has also been reported [676]. Valaciclovir and famciclovir are thought to have similar efficacy [643, 677], but Japanese researchers reported significantly faster pain relief with famciclovir [678]. In Caucasians, sirovudine treated acute $\mathrm{HZ}$ as safely and effectively as aciclovir but with fewer recurrences [679]; however, sirovudine has potentially fatal interactions with 5-fluorouracil prodrugs, which killed 18 Japanese cancer patients [680].

\section{Pain relief}

Pain control is crucial to HZ management, not only for acute analgesia, but also because pain severity predicts PHN [9, 643, 644]. Although prompt antiviral therapy reduces acute HZ-associated pain, an updated metaanalysis concluded that aciclovir does not reduce the incidence of PHN and found insufficient evidence to evaluate the effect of other antiviral agents [681]. In practice, antiviral therapy is usually given concomitantly with corticosteroids or analgesics, according to the degree of pain.

\section{Corticosteroids}

Oral corticosteroids relieve pain, accelerate lesion healing and hasten functional recovery; however, being immunosuppressive they cannot be given without concomitant antiviral therapy. Moreover, corticosteroids should be used with caution in patients with common comorbidities such as diabetes and hypertension and do not prevent or relieve PHN [643, 645, 646]. Nevertheless, corticosteroid injections have successfully treated cases of Ramsay Hunt syndrome and refractory PHN in Chinese patients $[682,683]$.

\section{Analgesia}

Pain relief should start early and be intensified as necessary during acute $\mathrm{HZ}$ to control pain and reduce the likelihood of developing PHN, which is much harder to treat $[656,684,685]$. Pain management steps-up from first-line acetaminophen or non-steroidal anti-inflammatory drugs to opioid narcotics for moderate-to-severe pain, to which anticonvulsants, tricyclic antidepressants or corticosteroids are added if pain remains uncontrolled [646]. The same second- and third-line analgesics are used to treat PHN if topical agents prove ineffective $[643,646]$.

Indian physicians have reported rapid and effective pain relief with topical acetylsalicylic acid dissolved in 


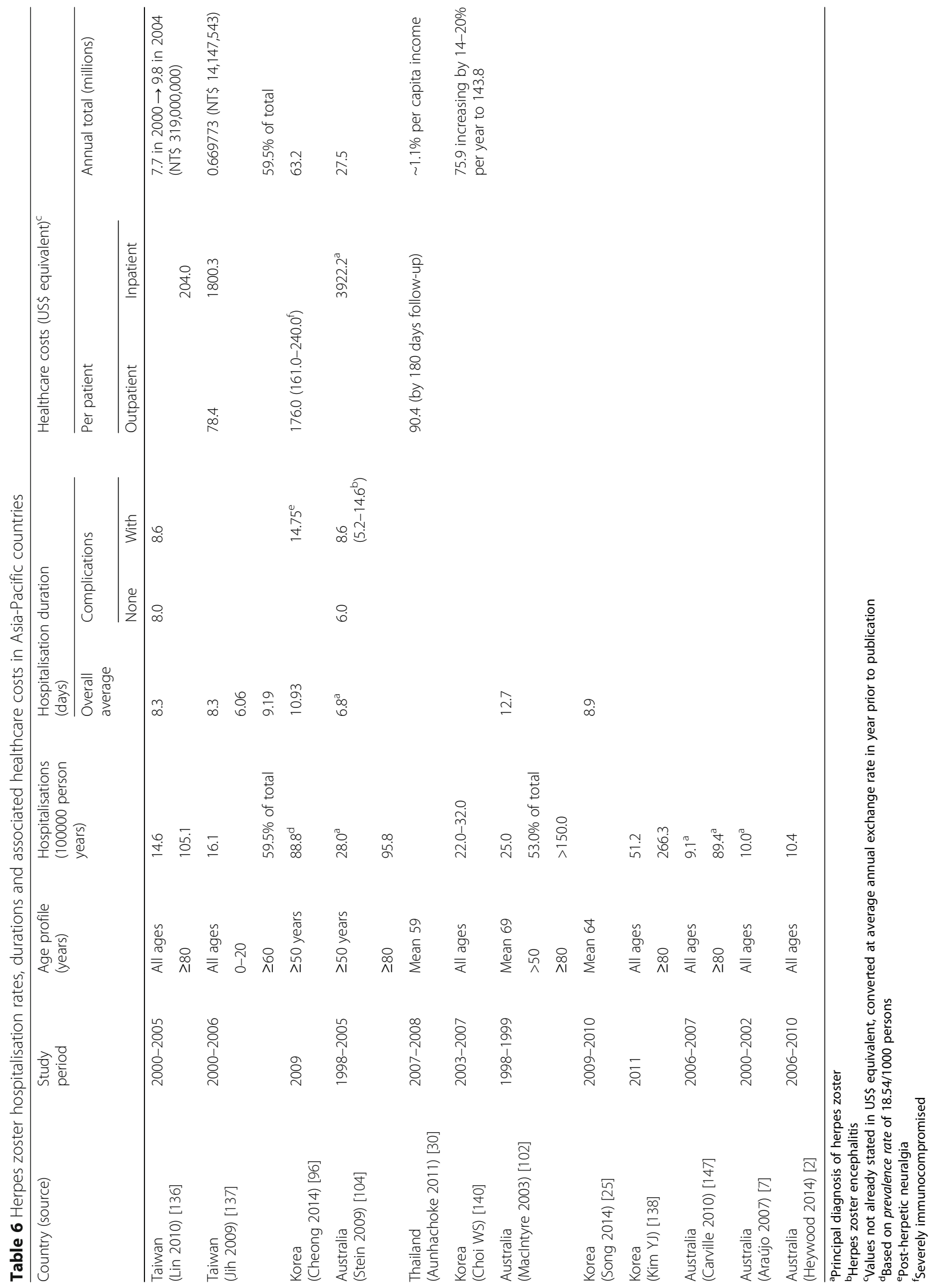


chloroform [686]. Others confirmed the efficacy of the anticonvulsants pregabalin and gabapentin for relieving acute herpetic pain $[687,688]$, and found pregabalin superior to amitriptyline for PHN [684]. Compared with placebo, pregabalin relieved PHN and was also associated with decreased sleep interference and significant improvements in health-related QoL [689]. Gabapentin is another effective and well-tolerated treatment for PHN [690] and combined with morphine in another trial, reduced pain more than either agent alone [691]. Chinese investigators found oxycodone-acetaminophen effective, safe and superior to other analgesics in $\mathrm{HZ}$ and PHN [692-696]. Reports from Australia, Japan, New Zealand and Taiwan have affirmed the efficacy of topical [697-699] or injected lidocaine [700, 701]. Transdermal fentanyl was found to be more effective than tramadol, providing excellent pain relief in $\mathrm{HZ}$ and $\mathrm{PHN}$ and improving QoL, both alone [702, 703] and combined with clodine [704]. Other experimental therapies with good reported outcomes in patients from Asia-Pacific countries include: topical interferon alpha [705, 706], adenine arabinoside (vidarabine) [707, 708], povidone-iodine [709], transdermal ribavirin [710], bromovinyl deoxyuridine (brivudin) [711], intravenous prostaglandin E1 [355, 712-715], the anticoagulant argatroban [716]; the tricyclic antidepressant milnacipran [717], human immunoglobulin [718], injected methylcobalamin [719], and botulinum toxin [720].

Nerve blockade is increasingly popular for treating intractable PHN or preventing PHN by reducing severe pain, particularly in East Asia [363, 721-742]; ambulatory patient-controlled systems have been successful in Taiwan [743, 744]. However, the true efficacy of nerve blocks is difficult to quantify because many trials were uncontrolled [9]. Furthermore, epidural injections require utmost caution due to the potential for infection and/or lifethreatening complications [745-755]. An implanted injection port may lessen the risk of infection [756].

Neurosurgery may trigger HZ [269-271] and though neuroablation has also been used, its efficacy is unproven and it may exacerbate PHN [757]; neuromodulation may provide an alternative but needs further investigation $[758,759]$.

\section{Alternative treatment modalities}

Asia-Pacific authors have contributed substantial literature on alternative $\mathrm{HZ}$ therapies (Additional file 1). Success has been reported with herbal decoctions, acupuncture and other traditional Chinese medicine techniques, energybased modalities, and combination therapies. Treatments evaluated in intractable $\mathrm{HZ}$ and PHN, include Ganoderma lucidum [760, 761], Keishikajutsubuto and Bushi-matsu [762], bee venom [763], intravenous vitamin C [764], computed tomography-guided radiofrequency thermo- coagulation [765], spinal cord stimulation [758], ultrasound-guided pulsed radiofrequency [766], and scrambler therapy [767]. Although many studies found these alternatives superior to conventional medicine, the strength of this evidence is dubious - due to conceptual differences between traditional Asian and Western medicine, many such studies do not conform to conventional evidence-based precepts [768-770].

\section{Unmet treatment needs}

Despite an armamentarium of potentially effective medications, current therapies have limitations and are not used to best advantage in older patients, who bear the brunt of HZ [646]. In particular, many patients start therapy too late, the optimal combination of therapies remains uncertain, antiviral agents are underprescribed $[22,645,771]$, and even with prompt intervention a substantial proportion remain refractory to treatment; up to $20 \%$ of patients with PHN still have persistent neuralgia after 6 months (Table 5) [18-20, 23, 28, 359, 771]. Aciclovir-resistant ocular VZV infections have been encountered [675, 676, 772, 773].

Given the substantial and rising burden of $\mathrm{HZ}$ and formidable treatment challenges facing physicians in the Asia-Pacific region, especially among elderly, immunocompromised or other high risk adults, such as those with renal disease, prevention is both rational and appealing $[20,25,94-96,104,136,140,144-147,160$, 644]. Accordingly, investigators have evaluated $\mathrm{HZ}$ prophylaxis with antiviral drugs or vaccines.

\section{Prevention approaches}

\section{Antiviral prophylaxis in high-risk patients}

$\mathrm{HZ}$ is a very common complication following HSCT $[170,774]$. Long-term prophylaxis with low-dose aciclovir [775-778] or valaciclovir [779] significantly reduces the incidence of VZV reactivation and serious complications, and is recommended for the duration of immunotherapy and continuing through 1 year after HSCT [776, 778]. Such prophylaxis also prevents HZ in patients receiving bortezomib [780, 781]. Similarly, no bone marrow transplant recipients developed HZ during 3-6 months of low-dose aciclovir and ganciclovir therapy; however, rapid onset of $\mathrm{HZ}$ after antiviral therapy was discontinued highlighted the need for ongoing prophylaxis [782]. Immunisation against VZV may be necessary to preclude $\mathrm{HZ}$ in high-risk patients [776]; therefore, Asian researchers have evaluated the potential of $\mathrm{HZ}$ prophylaxis with varicella vaccines.

\section{VZV immunisation}

A survey of Japanese paediatricians, who might have enhanced immunity through VZV re-exposures, confirmed 
lower incidence of HZ than the general population, suggesting that varicella vaccine may likewise protect against HZ [319]. Also in Japan, immunisation with live varicella vaccine (Oka/BIKEN) enhanced CMI to VZV in adults age $\geq 50$ years $[783,784]$, and in subjects aged 60 70 with or without diabetes [785]. A case of recurrent $\mathrm{HZO}$ cured by varicella vaccination was also reported [786]. In studies that evaluated live-attenuated VZV vaccine in HSCT [774, 787], Oka/RIT (Varilrix ${ }^{\text {mo }}$ GlaxoSmithKline Biologicals, Rixensart, Belgium) was safe but poorly immunogenic. A systematic review concluded that although inactivated VZV vaccine may reduce $\mathrm{HZ}$ severity in stem cell transplant recipients, more research was required [788]. Thus, alternative approaches to preventing $\mathrm{HZ}$ in such patients are probably needed [787].

During a 20-year endeavour to develop the first specific $\mathrm{HZ}$ vaccine, researchers reformulated Oka/Merck varicella vaccine (Varivax ${ }^{\oplus}$ Merck \& Co. Inc., Whitehouse Station, NJ, USA.) to produce a higher-titre live-attenuated VZV vaccine - Zostavax ${ }^{\odot}$ (Merck \& Co. Inc.) [10, 789]. In the culminating Shingles Prevention Study (SPS), Zostavax ${ }^{\circ}$ immunisation reduced the incidence of $\mathrm{HZ}$ among adults $\geq 60$ years old by $51 \%$, PHN by $67 \%$ and the HZ-related burden of illness by $61 \%$, as well as improving QoL and performance of daily activities in subjects who developed HZ [95]. The US Food and Drug Administration licenced Zostavax ${ }^{\circ}$ in 2006 [644]; it was also approved by the European Medicines Agency [96] and subsequently by authorities in Australia [644] New Zealand [652], Korea [790, 791], Malaysia [792], and other Asian countries [793-796]. The US Centers for Disease Control and Prevention Advisory Committee on Immunization Practices (ACIP), recommends routine vaccination for all noncontraindicated persons age $\geq 60$ years; importantly though, Zostavax ${ }^{\circ}$ is not indicated to treat extant $\mathrm{HZ}$ or PHN [10]. An independent review of SPS concluded that there is insufficient proof that Zostavax ${ }^{\circ}$ prevents PHN beyond reducing the incidence of HZ. Further, since SPS patients were predominantly Caucasian, its findings might not apply to other races [797].

Zostavax $^{\odot}$ in Asia-Pacific Production shortfalls of Zostavax $^{\ominus}$ after initial licensure restricted its supply $[1,2]$. Though since resolved, this issue affected vaccine availability and uptake in Asia-Pacific countries [2]. For example, 2011 vaccination rates among Australian inpatients in 2011 were $34 \%$ for $\mathrm{HZ}$, compared with $52 \%$ for pneumococcal vaccine and $64 \%$ for influenza [798]. This explains the scarcity of Asian data on Zostavax ${ }^{\circ}$. One pilot study of 21 healthy adults $\geq 30$ years old, including eight Filipinos, found Zostavax ${ }^{\circ}$ to be immunogenic and generally well-tolerated [799].
Cost-effectiveness The substantial economic burden of $\mathrm{HZ}$ includes direct healthcare costs as well as indirect costs of disability and lost productivity [10, 30, 140]. US and European researchers have modelled the pharmacoeconomics of $\mathrm{HZ}$ vaccination. US estimates of cost per quality-adjusted life-years gained (QALY), varied widely depending on the assumptions used. Routine immunisation at age 70 or 60 cost US\$ 37000 and US\$ 86000 respectively, within the range of standard thresholds, whereas the estimated cost of US\$ 287000 at age 50 was deemed too high [800]. Analyses in European countries predicted that vaccinating adults above the ages of $50,60,65$ or aged $70-79$ would be cost-effective, with high likelihood of not exceeding accepted thresholds of $£ 30000$ in the United Kingdom or $€ 30000$ in Belgium [801]. A systematic review of 11 US and European studies concluded that vaccination at age 65-70 would probably be cost-effective in terms of QALYs gained, assuming it confers more than 10-15 years' protection against PHN [802]; however, costeffectiveness data from high-income countries may not apply worldwide, because healthcare provision and costs differ considerably between nations [801, 802]. Although high and rising healthcare costs of treating $\mathrm{HZ}$ documented in several Asia-Pacific countries [30, 104, 136, $137,140]$ suggest that it would probably be no less costeffective to immunise elders from this region than others, specific pharmacoeconomic data are lacking [790, 802]; such analyses are needed urgently to resolve current uncertainties and inform evidence-based decision-making by healthcare funders and providers.

\section{$\mathrm{HZ}$ immunisation guidelines and recommendations}

Given the potential for $\mathrm{HZ}$ immunisation to efficaciously and safely reduce the associated burden of illness [10], as well as cost-effectiveness considerations, organisations in several Asia-Pacific countries have incorporated HZ vaccination into adult immunisation schedules (Table 7) [2, 5, 8, 642, 791-796]. Neither Japan nor Singapore has such guidelines and The Association of Physicians of India does not recommend $\mathrm{HZ}$ immunisation, due to lack of national epidemiology data [803].

Most HZ immunisation guidelines are published by professional societies, with only Australia and New Zealand having government-issued guidelines [8, 642]. Since Asian epidemiological and clinical data are sparse, local guidelines generally follow the ACIP [10], with very similar recommendations for indicated and non-licenced uses, administration, and precautions or contraindications (Table 8). Like ACIP, most Asia-Pacific guidelines recommend routine immunisation from age 60; however, some age thresholds vary. The New Zealand Ministry of Health and Indonesia Specialist Doctors Association both recommend immunisation from age 50 [642, 793], though 
this is not state funded. The Korean Society of Infectious Diseases recommends routine vaccination above age 65 [791], with vaccination from age 50 at patients' own discretion. Similarly, The Australian Department of Health [8] and the Malaysian Society of Geriatric Medicine [792] do not recommend routine vaccination for persons aged $50-59$, but sanction this as a personal option, with the caveats that the duration of protection remains undetermined. However, the Malaysian Society of Geriatric Medicine does not recommend vaccinating patients older than 80, due to lack of efficacy, and the Australian guidelines likewise note that vaccination may confer less clinical benefit in this age group [8]. The New Zealand guidelines [642] uniquely specify active untreated tuberculosis as a contraindication and the Australian guidelines are alone in indicating vaccination of persons from age 50 who are household contacts of immunocompromised individuals [8]. Based on evidence that co-administering Zostavax ${ }^{\circledR}$ with pneumococcal polysaccharide vaccine may reduce its immunogenicity compared with administration 4 weeks apart [804], the Australian and New Zealand Society for Geriatric Medicine recommended against giving these vaccines concomitantly [5]; however, a later study suggested that this may not compromise Zostavax ${ }^{\bullet}$ effectiveness [8, 805], and the Australian 2015 guidelines recommend that Zostavax ${ }^{\ominus}$ can be given at the same time as pneumococcal polysaccharide vaccine, using separate syringes and injection sites [8].

\section{Discussion}

Ours is the most comprehensive audit yet of $\mathrm{HZ}$ in the Asia-Pacific region. We have reviewed almost every available paper published on the subject over 21 years since 1994 in 14 countries whose populations constitute the majority of not only Asians, but indeed the global population. The information collated provides a valuable resource and reference by which to gauge future progress.

\section{Knowledge and data gaps}

Contrary to a preconception that there may be a dearth of Asian data, we discovered a wealth of evidence on all aspects of HZ. However, our review does affirm that Asian data are patchy; in particular, there is very little information from South-East Asian populations numbering hundreds of millions, which probably reflects pragmatic healthcare imperatives in resource-limited settings [3]. Limiting the scope of the survey to 21 years may have missed epidemiology data published prior to 1994 . The review may have excluded some relevant articles which did not specify that VZV infection was reactivated. It is also possible that some articles with no country affiliation field in the databases searched may have been overlooked; however, searching several databases reduced this possibility. Epidemiology data from Indonesia, Malaysia, the Philippines, and Vietnam are needed to provide a more balanced picture. There are

Table 7 Asia-Pacific guidelines for immunisation against herpes zoster

\begin{tabular}{|c|c|c|c|c|c|c|}
\hline \multirow[t]{2}{*}{ Country } & \multirow[t]{2}{*}{ Title } & \multicolumn{2}{|l|}{ Issuing organisation } & \multirow{2}{*}{$\begin{array}{l}\text { Year } \\
\text { (last update) }\end{array}$} & \multicolumn{2}{|c|}{ Age thresholds } \\
\hline & & Name & Status & & Routine & Optional \\
\hline Australia [8] & The Australian Immunisation Handbook & $\begin{array}{l}\text { Technical Advisory Group on } \\
\text { Immunisation }\end{array}$ & Government & 2015 & $60-79$ & \\
\hline $\begin{array}{l}\text { Australia \& } \\
\text { New Zealand [5] }\end{array}$ & Immunisation of Older People & $\begin{array}{l}\text { Australia \& New Zealand Society } \\
\text { for Geriatric Medicine }\end{array}$ & Society & 2011 & $\geq 60$ & \\
\hline India [803] & Medicine Update. Adult Immunization & Association of Physicians of India & Society & 2013 & $\begin{array}{l}\text { No } \\
\text { recomme }\end{array}$ & endation $^{a}$ \\
\hline Indonesia [793] & Adult Immunization Schedule & $\begin{array}{l}\text { Specialist Doctors Association of } \\
\text { Indonesia }\end{array}$ & Society & 2014 & $\geq 50$ & \\
\hline Malaysia [792] & $\begin{array}{l}\text { Position Statement on Vaccination Against } \\
\text { the Herpes Zoster Virus in Older Adults }\end{array}$ & $\begin{array}{l}\text { Malaysian Society of Geriatric } \\
\text { Medicine }\end{array}$ & Society & 2014 & $60-79$ & $50-59$ \\
\hline New Zealand [642] & Immunisation Handbook & New Zealand Ministry of Health & Government & 2016 & $>50$ & \\
\hline Philippines [794] & $\begin{array}{l}\text { Handbook on Adult Immunization for } \\
\text { Filipinos }\end{array}$ & $\begin{array}{l}\text { Philippine Society for Microbiology } \\
\text { and Infectious Diseases }\end{array}$ & Society & 2012 & $\geq 60$ & \\
\hline South Korea [791] & $\begin{array}{l}\text { Recommended Immunization Schedule } \\
\text { for Adults in Korea }\end{array}$ & $\begin{array}{l}\text { Korean Society of Infectious } \\
\text { Diseases }\end{array}$ & Society & 2012 & $>65$ & $50-59$ \\
\hline Taiwan [796] & Clinical Handbook for Adult Immunization & $\begin{array}{l}\text { Taiwan Association of Family } \\
\text { Medicine }\end{array}$ & Society & 2010 & $\geq 60$ & \\
\hline Thailand [795] & $\begin{array}{l}\text { Recommended Adult and Elderly } \\
\text { Immunization Schedule }\end{array}$ & $\begin{array}{l}\text { Thailand Royal College of } \\
\text { Physicians }\end{array}$ & Society & 2014 & $\geq 60$ & \\
\hline
\end{tabular}

${ }^{a}$ The Association of Physicians of India does not recommend herpes zoster vaccine for adults, due to lack of reliable data on the epidemiology and burden of herpes zoster in India 
Table 8 Concordance between herpes zoster immunisation recommendations from US ACIP and Asia-Pacific countries

\begin{tabular}{|c|c|}
\hline $\begin{array}{l}\text { Indications and } \\
\text { administration }\end{array}$ & $\begin{array}{l}\text { - Routine immunisation with one dose of } \\
\text { HZ vaccine for all persons age } \geq 60 \text { : } \\
\text { - With or without prior } \mathrm{HZ} \\
\text { - With chronic medical conditions (eg, chronic } \\
\text { kidney disease, diabetes, rheumatoid arthritis, } \\
\text { lung disease), except those listed as } \\
\text { contraindications or precautions } \\
\text { - HZ vaccine can be co-administered with other } \\
\text { indicated adult vaccines, eg, influenza }\end{array}$ \\
\hline $\begin{array}{l}\text { Unlicensed } \\
\text { categories/ } \\
\text { purposes }\end{array}$ & $\begin{array}{l}\text { - Persons immunised with varicella zoster vaccine } \\
\text { - Persons younger than the minimum } \\
\text { recommended or optional age threshold } \\
\text { - HZ vaccine is not to be used to treat existing } \\
\mathrm{HZ} \text { or its complications }\end{array}$ \\
\hline Precautions & $\begin{array}{l}\text { - Moderate/severe acute illness } \\
\text { - Anticipated immunosuppression } \\
\text { - Anti-herpetic pharmacotherapy }\end{array}$ \\
\hline Contraindications & $\begin{array}{l}\text { - Hypersensitivity to vaccine components } \\
\text { - Morbid or medical immunosuppression or } \\
\text { immunodeficiency: } \\
\text { - HIV/AIDS } \\
\text { - Transplant recipients } \\
\text { - Systemic immunosuppressive therapy } \\
\text { (including high-dose steroids and recombinant } \\
\text { immune modulators } \\
\text { - Pregnancy }\end{array}$ \\
\hline
\end{tabular}

HZ Herpes zoster, US ACIP United States Centers for Disease Control and Prevention Advisory Committee on Immunization Practices, HIV/AIDS human immunodeficiency virus/acquired immunodeficiency syndrome

also limited Asian data on the safety and efficacy of the $\mathrm{HZ}$ vaccine and, in particular, its cost-effectiveness $[137,140,790,802]$.

\section{Conclusions}

Data gaps notwithstanding, there is compelling evidence to conclude that the epidemiology and risk factors for $\mathrm{HZ}$ in the Asia-Pacific region are not remarkably different from those in Western populations [7]. However, with a vastly larger absolute aged population, Asia bears a unique burden of $\mathrm{HZ}$. The estimated number of Asians $^{1}$ age $>60$ in 2015 is 489,397,421, which by 2035 will nearly double to $924,520,454$ [806]. Assuming an annual incidence of $\mathrm{HZ}$ in unvaccinated individuals of approximately $12 / 1000$ person-years $[136,137]$, this equates to approximately 16089 new HZ cases daily in 2015 and 30395 in 2035, more than half of which might be prevented by $\mathrm{HZ}$ immunisation. Data affirming rising incidence of $\mathrm{HZ}$ in countries across Asia-Pacific bear out these projections. Consequently, HZ in the Asia-Pacific region exacts huge and increasing tolls of morbidity, debility and diminished life quality that incur significant healthcare expenditure and indirect socioeconomic costs [20, $25,30,96,104,136,137,140]$.

This review also highlights that $\mathrm{HZ}$ is uniquely complex among infectious diseases, often complicated and defies disciplinary boundaries. Despite a plethora of conventional and alternative treatments, none is singularly effective [25]; current approaches can go only so far to alleviating the disease burden, especially among the elderly who constitute most patients, and then at considerable expense [95]. Thus, the rationale for prevention is very strong [20,102, 145]. Yet although a specific $\mathrm{HZ}$ vaccine is available and recommended by immunisation guidelines in many countries, it remains underused. This typifies how preventive healthcare for the elderly continues to be neglected in Asia, despite repeated calls to make this a higher public health priority $[3,4,6]$. It is more urgent now than ever to address this situation.

\section{Call to action}

We look forward to being able to report in future that advances in preventive healthcare have alleviated the growing burden of $\mathrm{HZ}$ in the Asia-Pacific region. This audit is just a beginning - realising this ambition will be impossible without redoubled efforts by the medical fraternity, healthcare authorities and all other stakeholders to change prevailing mindsets and afford higher priority to adult immunisation in general and $\mathrm{HZ}$ in particular. We urge all concerned to heed this call to action.

\section{Endnotes}

${ }^{1}$ Afghanistan, Bangladesh, Bhutan, Brunei, Burma, Cambodia, China, Hong Kong, India, Indonesia, Iran, Japan, Laos, Macau, Malaysia, Maldives, Mongolia, Nepal, North Korea, Pakistan, Philippines, Singapore, South Korea, Sri Lanka, Taiwan, Thailand, Timor-Leste, Vietnam.

\section{Additional file}

Additional file 1: Appendix 1. Alternative approaches to treating herpes zoster and herpetic neuralgia. (PDF $340 \mathrm{~kb}$ )

\section{Abbreviations}

ACIP: Advisory Committee on Immunization Practices; AIDS: Acquired immunodeficiency syndrome; CLIPPERS: Chronic lymphocytic inflammation with pontine perivascular enhancement responsive to steroids; CMI: Cellmediated immunity; HAART: Highly-active antiretroviral therapy; HIV: Human immunodeficiency virus; HSCT: Haematopoietic stem cell transplant; HZ: Herpes zoster; HZO: Herpes zoster ophthalmicus; PHN: Post-herpetic neuralgia; PY: Person-years; QoL: Quality of life; SLE: Systemic lupus erythematosus; SPS: Shingles Prevention Study; US: United States; VZV: Varicella zoster virus; WHO: World Health Organization

\section{Acknowledgements}

MSD funded preparation of the manuscript, but had no role in designing the study, data collection or analysis, drafting or approving the manuscript, or the decision to submit for publication. The authors thank Dr. David Neil (PhD), of Content Ed Net (Taiwan) for providing professional medical writing services, which were remunerated by Merck Sharp \& Dohme (I.A.) Corp, Taiwan.

\section{Funding}

The authors received no specific research funding for the work described in this manuscript. 


\section{Availability of data and materials}

All supporting data are either contained within the manuscript or were excerpted from the sources cited, and can be shared upon request.

\section{Authors' contributions}

LKC conceived and coordinated the study, acquired and interpreted data, and revised manuscript drafts for important intellectual content. HA, LYC, SD, $B D, T K, X L, D M, J Y P, P J H P, S R$, TT, and CWW, refined the review protocol, provided and/or reviewed or interpreted data, and revised manuscript drafts for important intellectual content. MYC, KTK, HNL, EMFL, CKL, LNP, and ERSP, contributed to refining the review protocol, and reviewed data and manuscript drafts. All authors read and approved the final manuscript.

\section{Competing interests}

The authors are members of The Asia-Pacific Working Group for Herpes Zoster, which is supported financially by Merck Sharp \& Dohme (I.A.) Corp. (MSD), Taiwan, and received honoraria for consultancy services in this capacity. The authors declare no other competing interests besides membership of this MSD Advisory Board.

\section{Consent for publication}

Not applicable.

\section{Ethics approval and consent to participate}

Not applicable.

\section{Author details}

${ }^{1}$ Center for Geriatrics and Gerontology, Taipei Veterans General Hospital, No 201, Sec. 2, Shih-Pai Rd., Taipei 11217, Taiwan. ${ }^{2}$ Aging and Health Research Center, National Yang Ming University, Taipei, Taiwan. ${ }^{3}$ National Center for Geriatrics and Gerontology, 7-340 Morioka-cho, Obu, Aichi 474-8511, Japan. ${ }^{4}$ Center for Geriatrics and Gerontology, Kaohsiung Veterans General Hospital, No. 386 Ta-Chun 1st Rd., Kaohsiung 81362, Taiwan. ${ }^{5}$ Department of Internal Medicine, Faculty of Medicine, University of Indonesia, Salemba Raya No. 6, Jakarta 10430, Indonesia. ${ }^{6}$ The Center of Gerontology and Geriatrics, West China Medical School/West China Hospital, Sichuan University, No. 37 Guo Xue Xiang, Renmin Nan Lu, Chengdu, Sichuan 610041, China. ${ }^{7}$ Department of Geriatric Medicine, Graduate School of Medicine, The University of Tokyo, 7-3-1, Jongo, Bunkyo-ku, Tokyo 113-8655, Japan. ${ }^{8}$ Division of Infectious Diseases, Daegu Fatima Hospital, 99 Ayang-ro, Dong-gu, Daegu 710-600, Korea. ${ }^{9}$ Rophi Clinic, 38 Irrawaddy Rd. \#07-54/55, Mount Elizabeth Novena Specialist Centre, Singapore 329563, Singapore. ${ }^{10}$ Geriatric Medicine Centre (Healthy Ageing), Hong Kong Sanatorium and Hospital, 2 Village Rd. Happy Valley, Hong Kong S.A.R., China. ${ }^{11}$ Division of Neurology, Department of Internal Medicine, Kaohsiung Veterans General Hospital, Kaohsiung, Taiwan. ${ }^{12}$ Division of Geriatrics, Department of Internal Medicine, Peking Union Medical College Hospital, Beijing 100730, China. ${ }^{13}$ Apollo Institute of Medical Sciences and Research, Apollo Health City Campus, Jubilee Hills, Hyderabad 500096, India. ${ }^{14}$ National Skin Centre, 1 Mandalay Rd., Singapore 308205, Singapore. ${ }^{15}$ Geriatric Center, St. Luke's Medical Center, 279 E. Rodriguez Sr. Ave., Quezon City 1102, Philippines. ${ }^{16}$ Division of Geriatrics, Department of Medicine, University Malaya Medical Centre, Lembah Pantai, 59100 Kuala Lumpur, Malaysia. ${ }^{17}$ Ropata Medical Centre, Lower Hutt 5010, New Zealand. ${ }^{18}$ Division of Infectious Diseases, Department of Medicine, Chulalongkorn University, Bangkok 10330, Thailand. ${ }^{19}$ Department of Family Medicine, College of Medicine, Kyung Hee University, 1 Hoigi-dong, Dongdaemun-gu, Seoul 130-720, Korea.

Received: 5 March 2016 Accepted: 9 January 2017

Published online: 15 March 2017

\section{References}

1. Harpaz R, Hales CM, Bialek S. Update on herpes zoster vaccine: licensure for persons aged 50 through 59 years. MMWR Morb Mortal Wkly Rep. 2011;60:1528.

2. Heywood AE, Wang H, Macartney KK, Mclntyre P. Varicella and herpes zoster hospitalizations before and after implementation of one-dose varicella vaccination in Australia: an ecological study. Bull World Health Organ. 2014; 92:593-604.

3. Isahak I. Steering Committee for Prevention and Control of Infectious Diseases in Asia. Adult immunization-a neglected issue in Southeast Asia. Southeast Asian J Trop Med Public Health. 2000;31:173-84.
4. Verma R, Khanna P, Chawla S. Vaccines for the elderly need to be introduced into the immunization program in India. Hum Vaccin Immunother. 2014;10:2468-70.

5. Woodward M. Immunisation of older people. J Pharm Pract Res. 2012;42:316-22.

6. Wong SY. Adult vaccination update 2014. The Singapore Fam Physician. 2014;40:27-32.

7. Araújo LQ, Maclntyre CR, Vujacich C. Epidemiology and burden of herpes zoster and post-herpetic neuralgia in Australia, Asia and South America. Herpes. 2007;14(Suppl 2):40-4.

8. Australian Technical Advisory Group on Immunisation. The Australian Immunisation Handbook. 10th ed (updated June 2015). Canberra: Australian Government Department of Health. 2015. http://www.health.gov.au/internet/ immunise/publishing.nsf/content/7B28E87511E08905CA257D4D001DB1F8/ \$File/Aus-Imm-Handbook.pdf. Accessed 17 Jan 2017.

9. Thomas J. Herpes zoster: Complications and management. J Pak Assoc Dermatol. 2004;14:237-43.

10. Harpaz R, Ortega-Saznchez IR, Seward JF. Centers for Disease Control and Prevention (CDC). Prevention of herpes zoster: recommendations of the Advisory Committee on Immunization Practices (ACIP). MMWR Recomm Rep. 2008;57(RR-5):1-30.

11. Kim YM, Lee SY, Lee JS, Park YL, Whang KU, Cho MK, et al. Epidemiological and clinical study on herpes zoster in the Province of Chungcheongnam-do (2004-2006). Korean J Dermatol. 2008;46:1488-94.

12. Abdul Latheef EN, Pavithran K. Herpes zoster: a clinical study in 205 patients Indian J Dermatol. 2011;56:529-32.

13. Shukuwa T, Chen WY, Kobayashi A. Statistical analysis of herpes zoster observed at Sasebo City General Hospital. Nishinihon J Dermatol. 2002; 64:477-82.

14. Naveen KN, Tophakane RS, Hanumanthayya K, Pv B, Pai W. A study of HIV seropositivity with various clinical manifestation of herpes zoster among patients from Karnataka, India. Dermatol Online J. 2011;17:3.

15. Jara MFA, Roa FC. The clinical presentation of herpes zoster patients and predictors of postherpetic neuralgia: A 5-year retrospective study at the section of dermatology, University of the Philippines - Philippine General Hospital. J Phil Dermatol Soc. 2010;19:8-12.

16. Leung AYH, Yuen KY, Cheng VCC, Lie AKW, Liang R, Kwong YL. Clinical characteristics of and risk factors for herpes zoster after hematopoietic stem cell transplantation. Haematologica. 2002;87:444-6.

17. Reid JS, Ah WB. Herpes zoster (shingles) at a large New Zealand general practice: incidence over 5 years. N Z Med J. 2014;127:56-60.

18. Goh $C L$, Khoo L. A retrospective study of the clinical presentation and outcome of herpes zoster in a tertiary dermatology outpatient referral clinic. Int J Dermatol. 1997;36:667-72.

19. Song JY, Chung BS, Choi KC, Shin BS. A 5-year period clinical observation on herpes zoster and the incidence of postherpetic neuralgia (2002-2006); a comparative analysis with the historical control group of a previous study (1995-1999). Korean J Dermatol. 2008;46:431-6.

20. Tsai TF, Yao CA, Yu HS, Lan CC, Chao SC, Yang JH, et al. Herpes zosterassociated severity and duration of pain, health-related quality of life, and healthcare utilization in Taiwan: a prospective observational study. Int J Dermatol. 2015;54:529-36.

21. Song T. Statistical analysis of 522 cases of patient with herpes-zoster. Med J Wuhan Univ. 2002;23:379-82.

22. Wallis KA, Hood LJ, Rao K. Herpes zoster: when do patients present and who gets antiviral treatment? J Prim Health Care. 2014;6:108-13.

23. Kurokawa I, Kumano K, Murakawa K. Clinical correlates of prolonged pain in Japanese patients with acute herpes zoster. J Int Med Res. 2002;30:56-65.

24. Kang Cl, Choi CM, Hong SS, Kim HB, Kim NJ, Oh MD, et al. The incidence of herpes zoster in otherwise healthy young soldiers of Korean army. Infect Chemother. 2006;38:45-6.

25. Song $\mathrm{H}$, Lee J, Lee $M$, Choi WS, Choi JH, Lee MS, et al. Burden of illness, quality of life, and healthcare utilization among patients with herpes zoster in South Korea: a prospective clinical-epidemiological study. Int J Infect Dis. 2014;20:23-30.

26. Park SY, Kim JY, Kim CD, Kim CW, Lee KS. A clinical study on herpes zoster during the last 10-year-period (1994-2003). Korean J Dermatol. 2004;42:1531-5.

27. Das AL, Sayal SK, Gupta CM, Chatterjee M. Herpes zoster in patients with HIV infection. Indian J Dermatol Venereol Leprol. 1997;63:101-4.

28. Kurokawa I, Murakawa K, Kumano K. The change in zoster-associated pain treated with oral valaciclovir in immunocompetent patients with acute herpes zoster. Int J Clin Pract. 2007;61:1223-9. 
29. Sawhney MPS, Sharma YK, Sayal SK. Mode of detection of HIV infection - A retrospective study of 612 cases. Med J Armed Forces India. 2005;61:220-3.

30. Aunhachoke K, Bussaratid V, Chirachanakul P, Chua-Intra B, Dhitavat J, Jaisathaporn K, et al. Measuring herpes zoster, zoster-associated pain, postherpetic neuralgia-associated loss of quality of life, and healthcare utilization and costs in Thailand. Int J Dermatol. 2011;50:428-35.

31. Achar A, Chakraborty PP, Ghosh T, Naskar B, Guharay T, Bisai S. Clinical efficacy and tolerability of valacyclovir versus acyclovir in treatment of herpes zoster. Iran J Dermatol. 2011;14:52-7.

32. Kim CG, Na CH, Choi KC, Shin BS. A comparative study of the clinical findings associated with herpes zoster and according to age. Korean J Dermatol. 2009;47:1338-44

33. Kim HJ, Sung HC, Kim DW, Lee WJ, Lee SJ, Na GY. Clinical features of herpes zoster according to immune state. Korean J Dermatol. 2006;44:149-56.

34. Cockburn DM, Douglas IS. Herpes zoster opthalmicus. Clin Exp Optom. 2000;83:59-64

35. Naveen KN, Pradeep AV, Kumar JS, Hegde SP, Pai W, Athanikar SB. Herpes zoster affecting all three divisions of trigeminal nerve in an immunocompetent male: a rare presentation. Indian J Dermatol. 2014;59:423.

36. Sangeeta N, Robindro Singh W, Brajach SO. Herpes zoster in a healthy adult: Report of a case with oro-cutaneous presentations. JMS J Med Soc. 2011;25:99-101.

37. Watanabe K, Funaki M. Images in clinical medicine: Zoster of the tympanic membrane. N Engl J Med. 2011;365:e40

38. Hong SB, Lee JW, Chang SG, Lee MH, Haw CR. Herpes zoster of the penis. Korean J Urol. 2005;46:1001-3.

39. Gopalan V, Nair RG, Pillai S, Oberholzer T. Genital herpes zoster as a consequence of cancer chemotherapy-induced immunosuppression: report of a case. J Infect Chemother. 2012;18:955-7.

40. Watanabe D, Kuhara T, Ishida N, Takama H, Tamada Y, Matsumoto Y. Herpes zoster of the nipple: rapid DNA-based diagnosis by the loop-mediated isothermal amplification method. Int J STD AIDS. 2010;21:66-7.

41. Izu K, Yamamoto O, Yasumoto S, Hashimoto T, Sata T, Tokura Y. Herpes zoster occurring as a solitary nodule on the index finger. Br J Dermatol. 2004;150:365-6.

42. Chen WH, Li TH, Lee LH, Huang CC. Varicella-zoster virus infection and nummular headache: a possible association with epicranial neuralgia. Intern Med. 2012;51:2439-41.

43. Hon C, Au WY, Cheng VC. Ophthalmic zoster sine herpete presenting as oculomotor palsy after marrow transplantation for acute myeloid leukemia. Haematologica. 2005;90 Suppl 12:EIM04.

44. Kim YH, Choi IJ, Kim HM, Ban JH, Cho CH, Ahn JH. Bilateral simultaneous facial nerve palsy: clinical analysis in seven cases. Otol Neurotol. 2008;29:397-400.

45. Furuta Y, Fukuda S, Suzuki S, Takasu T, Inuyama Y, Nagashima K. Detection of varicella-zoster virus DNA in patients with acute peripheral facial palsy by the polymerase chain reaction, and its use for early diagnosis of zoster sine herpete. J Med Virol. 1997;52:316-9.

46. Fujiwara K, Furuta Y, Fukuda S. A case of associated laryngeal paralysis caused by varicella zoster virus without eruption. Case Rep Med. 2014;2014:916265.

47. Powell KF, Wilson HG, Croxson MC, Marshall MR, Wong EH, Anderson NE, et al. Herpes zoster meningoencephalitis without rash: Varicella zoster virus DNA in CSF. J Neurol Neurosurg Psychiatry. 1995:59:198-9.

48. Chen MJ, Chen KH, Chung YM, Li AF, Chou CK, Hsu WM. Detection of varicella-zoster virus DNA in the iris of a zoster sine herpete patient. Int J Biomed Sci. 2006;2:302-4.

49. Lo CH, Chiang CP. Herpes zoster duplex bilateralis. Intern Med. 2013;52:2841.

50. Shin JW, Kim DH, Whang KU, Lee J, Park Y, Cho MK, et al. A case of zoster duplex bilateralis. Ann Dermatol. 2009;21:423-5.

51. Mabuchi T, Yamaoka H, Kato M, Ikoma N, Tamiya S, Song HJ, et al. Case of disseminated vesicles of herpes zoster developing one day before the onset of local eruption in a hospitalized immunocompromised patient. Tokai J Exp Clin Med. 2013;38:52-4.

52. Kim H, Kang JN, Seol JE, Seo JK, Sung HS. Epidemiology and clinical features of disseminated herpes zoster. Korean J Dermatol. 2013;51:507-12.

53. Qi X-L, Li C-X, Gao T-W. Herpes zoster generalisatus caused by long-term treatment of cyclosporin: A case report. J Clin Dermatol. 2006;35:313-14.

54. Park S-H, Lee SY, Yi JH, Choi HS, Yun SK, Kim HU, Ihm CW. A case of herpes zoster duplex unilateralis with herpes zoster generalisatus. Korean J Dermatol. 2005;43:1579-81.

55. Takaoka Y, Miyachi Y, Yoshikawa Y, Tanioka M, Fujisawa A, Endo Y. Bilateral disseminated herpes zoster in an immunocompetent host. Dermatol Online J. 2013;19:13.
56. Gupta LK, Kuldeep CM, Mittal A, Singhal H. Multidermatomal herpes zoster in an immunocompetent female. Indian J Dermatol Venereol Leprol. 2005;71:210-11.

57. Sun ZH, Guo YY, Li M, Yao ZR. Disseminated herpes zoster in immunocompetent patients not due to varicella-zoster virus gene mutation. Chin Med J. 2013;126:3193.

58. Mittal RR. Disseminated herpes zoster. Indian J Dermatol Venereol Leprol. 1995;61:148-9.

59. Gahalaut P, Chauhan S. Herpes zoster duplex bilateralis in an immunocompetent host. Indian Dermatol Online J. 2012;3:31-3.

60. Lee H, Jung HJ, Park MY, Ann JY. Herpes zoster duplex symmetricus in a healthy patient. Korean J Dermatol. 2011;49:1098-101.

61. Tsai YC, Tsai TF. Herpes zoster duplex bilateralis symmetricus. Dermatol Sin. 2015:33:37-8.

62. Yoon KJ, Kim SH, Lee EH, Choi JH. Disseminated herpes zoster in an immunocompetent elderly patient. Korean J Pain. 2013;26:195-8.

63. Brar BK, Gupta RR, Saghni SS. Bilateral herpes - zoster of widely separated dermatomes in a non-immunocompromised female. Indian J Dermatol Venereol Leprol. 2002;68:48-9.

64. Agrawal S, Aara N, Bumb R. Herpes zoster duplex bilateralis symmetricus in an immunocompetent subject. Int J Dermatol. 2014;53:e281-2.

65. Oh KH, Ahn C, Kim YS, Han JS, Kim S, Lee JS, et al. Atypical generalized zoster with suspicious esophageal involvement and early relapse in an adult renal transplant recepient. Transplant Proc. 2002;34:1174-7.

66. Tan HH, Goh CL. Viral infections affecting the skin in organ transplant recipients: epidemiology and current management strategies. Am J Clin Dermatol. 2006;7:13-29.

67. Kui YP, Hye IL, Ji YK, Kap SL, Seong JS, Chang KH. A case of herpes zoster multiplex in five disparate dermatomes. Korean J Dermatol. 2008; 46:973-6.

68. Yoo KH, Park JH, Kim BJ, Kim MN, Song KY. Herpes zoster duplex bilateralis in a patient with breast cancer. Cancer Res Treat. 2009;41:50-2.

69. Ko DH, Park SY, Yoon TJ. A case of bilateral recurrent herpes zoster in multiple myeloma. Korean J Dermatol. 2006:44:1460-3.

70. Teranishi H, Sakiyama M, Nagatoshi Y, Nomura Y, Inagaki J, Yanai F, et al. Acute lymphoblastic leukemia complicated with varicella zoster virus meningoencephalitis and visceral dissemination after related bone marrow transplantation. Rinsho Ketsueki. 2011;52:287-92.

71. Endoh K, Kawai N, Itoh K, Tominaga K, Kusumoto S, Fukuda M, et al. An autopsy case of non-Hodgkin's lymphoma complicated by fulminant infiltration by disseminated herpes zoster. Jpn J Chemother. 2000;48:75-8.

72. Ryu DJ, Jung JY, Lee S, Lee JH. A case of herpes zoster duplex bilateralis, a diagnostic clue of human immunodeficiency virus infection. Korean J Dermatol. 2010;48:339-41.

73. Rajashekar TS, Singh G, Shivakumar V, Okade R. Recurrent herpes zoster duplex symmetricus in HIV infection. Indian J Dermatol. 2008;53:33-4

74. Sundriyal D, Kapoor R, Kumar N, Walia M. Multidermatomal herpes zoster. BMJ Case Rep. 2014. doi:10.1136/bcr-2014-205024

75. Zhang B, Zhao HX, Lun WH, Sun N, Yang D, Liang HY, et al. Generalized varicella-zoster virus infection: A case report. J Clin Dermatol. 2013:42:595-7.

76. Chacko S, John TJ, Babu PG, Jacob M, Kaur A, Mathai D. Clinical profile of AIDS in India: a review of 61 cases. J Assoc Physicians India. 1995;43:535-8.

77. Higashitake I, Higaki T, Souda N, Yamada H. Recurrent herpes zoster seen in the patient of human immunodeficiency virus infection. Skin Res. 2004;3:216-9.

78. Kar HK, Gautam RK, Jain RK, Puri P, Doda V. Disseminated cutaneous herpes zoster: A clinical predictor of human immunodeficiency virus infection. Indian J Dermatol Venereol Leprol. 1995;61:40-1.

79. Shin BS, Na CH, Song IG, Choi KC. A case of human immunodeficiency virus infection initially presented with disseminated herpes zoster. Ann Dermatol. 2010;22:199-202.

80. Kim WJ, Park JW, Shin DH, Choi JS, Kim KH. A case of human immunodeficiency virus infection in recurrent herpes zoster. Korean J Dermatol. 2005;43:271-3

81. Kim MS, Choi H, Na CH, Shin BS. A 5-year period clinical study of 16 cases with disseminated herpes zoster (2008-2012). Korean J Dermatol. 2013:51:322-8.

82. Doki N, Miyawaki S, Tanaka M, Kudo D, Wake A, Oshima K, et al. Visceral varicella zoster virus infection after allogeneic stem cell transplantation. Transpl Infect Dis. 2013;15:314-8.

83. Saitoh H, Takahashi N, Nanjo H, Kawabata Y, Hirokawa M, Sawada K Varicella-zoster virus-associated fulminant hepatitis following allogeneic hematopoietic stem cell transplantation for multiple myeloma. Intern Med. 2013;52:1727-30. 
84. Ni XS, Ouyang J, Zhu WH, Wang C, Chen B. Autologous hematopoietic stem cell transplantation for progressive multiple sclerosis: report of efficacy and safety at three yr of follow up in 21 patients. Clin Transplant. 2006;20:485-9.

85. Ohara F, Kobayashi Y, Akabane D, Maruyama D, Tanimoto K, Kim SW, et al. Abdominal pain and syndrome of inappropriate antidiuretic hormone secretion as a manifestation of visceral varicella zoster virus infection in a patient with non-Hodgkin's lymphoma. Am J Hematol. 2007;82:416.

86. Yakushijin Y, Minamoto Y, Takada K, Otsuka M, Yasukawa M, Fujita S. A case of fatal varicella zoster infection with refractory abdominal pain as an early symptom. Kansenshogaku Zasshi. 2004;78:64-9.

87. Au WY, Ma SY, Cheng VC, Ooi CG, Lie AK. Disseminated zoster, hyponatraemia, severe abdominal pain and leukaemia relapse: recognition of a new clinical quartet after bone marrow transplantation. Br J Dermatol. 2003;149:862-5.

88. Kurtovic J, Webster GJM, Singh-Grewal I, Bullpitt P, Haindl W, Wakefield D, et al. Acalculous cholecystitis, multifocal gastrointestinal infarction and pancreatitis resulting from Varicella-zoster virus. Intern Med J. 2005;35:69-70.

89. Wang Z, Ye J, Han YH. Acute pancreatitis associated with herpes zoster: Case report and literature review. World J Gastroenterol. 2014;20:18053-6.

90. Okimura H, Muto M, Ichimiya M, Mogami S, Takahata H, Asagami C. A case of herpes zoster associated with colitis. J Dermatol. 1996;23:631-4.

91. Ching DW. Severe, disseminated, life threatening herpes zoster infection in a patient with rheumatoid arthritis treated with methotrexate. Ann Rheum Dis. 1995;54:155

92. Hashizume $H$, Umayahara T. Acute respiratory distress syndrome due to varicella zoster virus pneumonitis in an immunocompromised patient with herpes zoster. J Dermatol. 2013;40:1064-5.

93. Nakamura M, Kanazawa M, Yamaguchi K, Akizuki M, Satoh S, Inada S. Pneumonia caused by varicella-zoster virus in a patient with rheumatoid arthritis. Nihon Kyobu Shikkan Gakkai Zasshi. 1996;34:610-5.

94. Miyazaki T, Tanabe Y, Iseki M. Treatment and recent topics of postherpetic neuralgia. Japan Med Assoc J. 2005:48:505-10.

95. Sanford M, Keating GM. Zoster vaccine (Zostavax): a review of its use in preventing herpes zoster and postherpetic neuralgia in older adults. Drugs Aging. 2010;27:159-76.

96. Cheong C, Lee TJ. Prevalence and healthcare utilization of herpes zoster and postherpetic neuralgia in South Korea: disparity among patients with different immune statuses. Epidemiol Health. 2014;36:e2014012.

97. Higa K, Mori M, Hirata K, Hori K, Manabe H, Dan K. Severity of skin lesions of herpes zoster at the worst phase rather than age and involved region most influences the duration of acute herpetic pain. Pain. 1997;69:245-53.

98. Sagong C, Yeo KY, Kim JS, Yu HJ, Kim DH. The relationship among pain, depression, and anxiety in patients with herpes zoster. Korean J Dermatol. 2009:47:403-10.

99. Decroix J, Partsch H, Gonzalez R, Mobacken H, Goh CL, Walsh JB, et al. Factors influencing pain outcome in herpes zoster: An observational study with valaciclovir. J Eur Acad Dermatol Venereol. 2000;14:23-33.

100. Noh TW, Park HJ, Kim SH, Kang YS, Lee UH, Park HS. A clinical study of herpes zoster focused on the characteristics of pruritus in herpes zoster. Korean J Dermatol. 2012;50:591-8.

101. Chant KG, Sullivan EA, Burgess MA, Ferson MJ, Forrest JM, Baird LM, et al. Varicella-zoster virus infection in Australia. Aust N Z J Public Health. 1998;22:413-8.

102. Maclntyre CR, Chu CP, Burgess MA. Use of hospitalization and pharmaceutical prescribing data to compare the prevaccination burden of varicella and herpes zoster in Australia. Epidemiol Infect. 2003;131:675-82.

103. Lee BW. Review of varicella zoster seroepidemiology in India and Southeast Asia. Trop Med Int Health. 1998;3:886-90.

104. Stein AN, Britt H, Harrison C, Conway EL, Cunningham A, Macintyre CR. Herpes zoster burden of illness and health care resource utilisation in the Australian population aged 50 years and older. Vaccine. 2009;27:520-9.

105. Dashraath P, Ong ES, Lee VJ. Seroepidemiology of varicella and the reliability of a self-reported history of varicella infection in Singapore military recruits. Ann Acad Med Singapore. 2007;36:636-41.

106. Chow VTK. Rapid detection of varicella-zoster viral antibodies by latex agglutination assay: A practical experience for medical and science undergraduates. Biochem Educ. 1998;26:248-51.

107. Fatha N, Ang LW, Goh KT. Changing seroprevalence of varicella zoster virus infection in a tropical city state, Singapore. Int J Infect Dis. 2014;22:73-7.

108. Juffrie M, Graham RR, Tan RI, Widjaja S, Mulyadi S, Weil J, et al, Seroprevalence of hepatitis A virus and varicella zoster antibodies in a
Javanese community (Yogyakarta, Indonesia). Southeast Asian J Trop Med Public Health. 2000;31:21-4.

109. Sam IC, Tariman H, Chan YF, Bador MK, Yusof MY, Hassan H. Varicella-zoster virus seroprevalence in healthcare workers in Kuala Lumpur, Malaysia. Med J Malaysia. 2008;63:429-30

110. Barzaga NG, Roxas JR, Florese RH. Varicella zoster virus prevalence in Metro Manila, Philippines. J Am Med Assoc (SE Asia). 1994;274(Suppl):S633-35.

111. Lokeshwar MR, Agrawal A, Subbarao SD, Chakraborty MS, Ram Prasad AV, Weil J, et al. Age related seroprevalence of antibodies to varicella in India. Indian Pediatr. 2000;37:714-9.

112. Migasena $S$, Simasathien $S$, Desakorn $V$, Phonrat B, Suntharasamai $P$, Pitisuttitham $P$, et al. Seroprevalence of varicella-zoster virus antibody in Thailand. Int J Infect Dis. 1997;2:26-30.

113. Bhattarakosol P, Chantarabul S, Pittayathikhun K, Mung-mee V, Punnarugsa $\checkmark$. Prevalence of anti-varicella zoster lgG antibody in undergraduate students. Asian Pac J Allergy Immunol. 1996;14:129-31.

114. Lolekha S, Tanthiphabha W, Sornchai P, Kosuwan P, Sutra S, Warachit B, et al. Effect of climatic factors and population density on varicella zoster virus epidemiology within a tropical country. Am J Trop Med Hyg. 2001;64:131-6.

115. Srichomkwun P, Apisarnthanarak A, Thongphubeth K, Yuekyen C, Mundy LM. Evidence of vaccine protection among Thai medical students and implications for occupational health. Infect Control Hosp Epidemiol. 2009;30:585-8.

116. Suwanpakdee D, Laohapand C, Moolasart V, Lomtong P, Krairojananan N, Srisawat $P$, et al. Serosurveillance of varicella and hepatitis B infection after reported cases in medical students and the relationship between past varicella disease history and immunity status. J Med Assoc Thai. 2012;95 Suppl 5:S80-5.

117. Kowitdamrong E, Pancharoen C, Thammaborvorn R, Bhattarakosol P. The prevalence of varicella-zoster virus infection in normal healthy individuals aged above 6 months. J Med Assoc Thai. 2005;88 Suppl 4:S7-11.

118. O'Grady KA, Merianos A, Patel M, Gilbert L. High seroprevalence of antibodies to varicella zoster virus in adult women in a tropical climate. Trop Med Int Health. 2000;5:732-6.

119. Gidding HF, Maclntyre CR, Burgess MA, Gilbert GL. The seroepidemiology and transmission dynamics of varicella in Australia. Epidemiol Infect. 2003; 131:1085-9.

120. Lin YJ, Huang LM, Lee CY, Chih TW, Lee PL, Chang LY, et al. A seroepidemiological study of Varicella-Zoster virus in Taipei City. Zhonghua Min Guo Xiao Er Ke Yi Xue Hui Za Zhi. 1996;37:11-5.

121. Wu MF, Yang YW, Lin WY, Chang CY, Soon MS, Liu CE. Varicella zoster virus infection among healthcare workers in Taiwan: seroprevalence and predictive value of history of varicella infection. J Hosp Infect. 2012;80:162-7.

122. Kangro HO, Osman HK, Lau YL, Heath RB, Yeung CY, Ng MH. Seroprevalence of antibodies to human herpesviruses in England and Hong Kong. J Med Virol. 1994;43:91-6.

123. Fung LW, Lao TT, Suen SS, Chan OK, Lau TK, Ngai KL, et al. Seroprevalence of varicella zoster virus among pregnant women in Hong Kong: comparison with self-reported history. Vaccine. 2011;29:8186-8

124. Liu JJ, Wang ML, Gan L, Liao WJ, Chen J. Seroepidemiology of varicellazoster virus infection measured by the fluorescent antibody to membrane antigen test. Zhonghua Liu Xing Bing Xue Za Zhi. 2009;30:371-5.

125. Zhou Z, Wang S, Chu Y, Xie G. Survey of seroprevalence of varicella zoster virus in healthy population in Shanghai. Chin J Vaccin Immun. 2006;2:137-9.

126. Wang Y. Seroepidemiological survey of prevalence of varicella-zoster virus in healthy population in Shenzen City. Chin Trop Med. 2006;7:1166-7.

127. Pan W, Zhang X, Cai Z, Zhang H. A sero-epidemiological investigation on varicella-zoster virus in healthy people in Fujian. Pract Prev Med. 2003;6: $864-5$.

128. Han SB, Kang KR, Huh DH, Lee HC, Kim JH, Kang JH, et al. Seroepidemiology of varicella-zoster virus in Korean adolescents and adults using fluorescent antibody to membrane antigen test. Epidemiol Infect. 2015;143:1643-50.

129. Kang Cl, Choi CM, Park TS, Lee DJ, Oh MD, Choe KW. Incidence of herpes zoster and seroprevalence of varicella-zoster virus in young adults of South Korea. Int J Infect Dis. 2008;12:245-7.

130. Choi YJ, Kim KH, Oh MD. Genotype of varicella zoster virus isolated from Korean elderly patients with herpes zoster. Infect Chemother. 2010;42:162-70.

131. Lee H, Cho HK, Kim KH. Seroepidemiology of varicella-zoster virus in Korea. Jorean Med Sci. 2013;28:195-9.

132. Kang JH, Park YS, Park SY, Kim SB, Ko KP, Seo YH. Varicella seroprevalence among health care workers in Korea: validity of self-reported history and costeffectiveness of prevaccination screening. Am J Infect Control. 2014;42:885-7. 
133. Kim YH, Hwang JY, Lee KM, Choi JH, Lee TY, Choi JS, et al. Seroepidemiologic survey of varicella-zoster virus in Korean adults using glycoprotein enzyme immuno assay and fluorescent antibody to membrane antigen test. Ann Dermatol. 2011;23:39-43.

134. Yoshida N, Tsumura N, Toyomasu K, Sagawa K. Antibody titers against measles, rubella, mumps and varicella-zoster viruses in medical students. Sangyo Eiseigaku Zasshi. 2007;49:21-6.

135. National Institute of Infectious Diseases, Japan. National Epidemiological Surveillance of Vaccine-Preventable Diseases, 2015. Age distribution of varicella EIA-IgG antibody positives in Japan, 2015. http://www.nih.go. jp/niid/ja/y-graphs/6358-varicella-yosoku-serum2015.html. Accessed 27 Sept 2016.

136. Lin YH, Huang LM, Chang IS, Tsai FY, Lu CY, Shao PL, et al. Disease burden and epidemiology of herpes zoster in pre-vaccine Taiwan. Vaccine. 2010;28: 1217-20.

137. Jih JS, Chen YJ, Lin MW, Chen YC, Chen TJ, Huang YL, et al. Epidemiological features and costs of herpes zoster in Taiwan: a national study 2000 to 2006. Acta Derm Venereol. 2009;89:612-6.

138. Kim YJ, Lee CN, Lim CY, Jeon WS, Park YM. Population-based study of the epidemiology of herpes zoster in Korea. J Korean Med Sci. 2014;29:1706-10.

139. Toyama N, Shiraki K. Epidemiology of herpes zoster and its relationship to varicella in Japan: A 10-year survey of 48,388 herpes zoster cases in Miyazaki prefecture. J Med Virol. 2009;81:2053-8.

140. Choi WS, Noh JY, Huh JY, Jo YM, Lee J, Song JY, et al. Disease burden of herpes zoster in Korea. J Clin Virol. 2010;47:325-9.

141. Wu PY, Wu HD, Chou TC, Sung FC. Varicella vaccination alters the chronological trends of herpes zoster and varicella. PLoS One. 2013:8:e77709.

142. Wu CY, Hu HY, Huang N, Pu CY, Shen HC, Chou YJ. Do the health-care workers gain protection against herpes zoster infection? A 6-year population-based study in Taiwan. J Dermatol. 2010;37:463-70.

143. Chao DY, Chien YZ, Yeh YP, Hsu PS, Lian IB. The incidence of varicella and herpes zoster in Taiwan during a period of increasing varicella vaccine coverage, 2000-2008. Epidemiol Infect. 2012;140:1131-40.

144. Pongsumpun P. Local stability analysis of age structural model for herpes zoster in Thailand. Int J Math Comput Stat Nat Phys Eng. 2013;7:1146-52.

145. Nelson MR, Britt HC, Harrison CM. Evidence of increasing frequency of herpes zoster management in Australian general practice since the introduction of a varicella vaccine. Med J Aust. 2010:193:110-3.

146. Kelly HA, Grant KA, Gidding H, Carville KS. Decreased varicella and increased herpes zoster incidence at a sentinel medical deputising service in a setting of increasing varicella vaccine coverage in Victoria, Australia, 1998 to 2012. Euro Surveill. 2014;19(41):pii=20926. http://www.eurosurveillance.org/ ViewArticle.aspx?Articleld=20926.

147. Carville KS, Riddell MA, Kelly HA. A decline in varicella but an uncertain impact on zoster following varicella vaccination in Victoria, Australia. Vaccine. 2010;28:2532-8

148. Bak H, Ahn SK. A statistical study of dermatoses (2000-2004). Korean J Dermatol. 2005;43:1192-9.

149. Lee H-J, Choi SI, Ahn SK. A statistical study of dermatoses in Wonju (2005 2009). Korean J Dermatol. 2010;48:460-7.

150. Bureau of Epidemiology, Department of Disease Control, Ministry of Public Health, Thailand. Annual Epidemiological Surveillance Reports. 1993-2014. http://www.boe.moph.go.th/boedb/surdata/disease.php?dcontent=old\&ds= 77. Accessed 03 Aug 2015.

151. Ogunjimi B, Van Damme P, Beutels P. Herpes zoster risk reduction through exposure to chickenpox patients: A systematic multidisciplinary review. PLoS One. 2013;8:e66485

152. Jardine A, Conaty SJ, Vally H. Herpes zoster in Australia: Evidence of increase in incidence in adults attributable to varicella immunization? Epidemiol Infect. 2011;139:658-65.

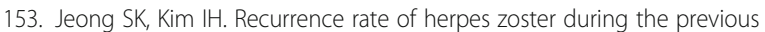
decade. Korean J Dermatol. 2012:50:287-9.

154. Tunsuriyawong S, Puavilai S. Herpes zoster, clinical course and associated diseases: A 5-year retrospective study at Ramathibodi Hospital. J Med Assoc Thai. 2005;88:678-81

155. Ikeda M, Hiroshige K, Abiko Y, Onoda K. Impaired specific cellular immunity to the varicella-zoster virus in patients with herpes zoster oticus. J Laryngol Otol. 1996;110:918-21.

156. Tang H, Moriishi E, Okamoto S, Okuno Y, Iso H, Asada H, et al. A community-based survey of varicella-zoster virus-specific immune responses in the elderly. J Clin Virol. 2012:55:46-50.
157. Lin SY, Liu JH, Lin CL, Tsai IJ, Chen PC, Chung CJ, et al. A comparison of herpes zoster incidence across the spectrum of chronic kidney disease, dialysis and transplantation. Am J Nephrol. 2012;36:27-33.

158. Hata A, Kuniyoshi M, Ohkusa Y. Risk of Herpes zoster in patients with underlying diseases: a retrospective hospital-based cohort study. Infection. 2011:39:537-44

159. Kuo CC, Lee CT, Lee IM, Ho SC, Yang CY. Risk of herpes zoster in patients treated with long-term hemodialysis: a matched cohort study. Am J Kidney Dis. 2012:59:428-33.

160. Wu MY, Hsu YH, Su CL, Lin YF, Lin HW. Risk of herpes zoster in CKD: a matchedcohort study based on administrative data. Am J Kidney Dis. 2012;60:548-52

161. Chen HH, Chen YM, Chen TJ, Lan JL, Lin CH, Chen DY. Risk of herpes zoster in patients with systemic lupus erythematosus: a three-year follow-up study using a nationwide population-based cohort. Clinics (Sao Paulo). 2011;66: 1177-82.

162. Tsai SY, Yang TY, Lin CL, Tsai YH, Kuo CF, Kao CH. Increased risk of varicella zoster virus infection in inflammatory bowel disease in an Asian population: a nationwide population-based cohort study. Int J Clin Pract. 2015;69:228-34.

163. Chen JY, Cheng TJ, Chang CY, Lan KM, Weng SF, Sheu MJ, et al. Increased incidence of herpes zoster in adult patients with peptic ulcer disease: A population-based cohort study. Int J Epidemiol. 2013:42:1873-81.

164. Yang YW, Chen YH, Wang KH, Wang CY, Lin HW. Risk of herpes zoster among patients with chronic obstructive pulmonary disease: a populationbased study. CMAJ. 2011;183:E275-80.

165. Umezawa $Y$, Fukuchi $O$, Ito $T$, Saeki $H$, Nakagawa $H$. Risk of herpes zoster in psoriatic patients undergoing biologic treatment. J Dermatol. 2014; $41: 168-70$

166. Hu SC, Lin CL, Lu YW, Chen GS, Yu HS, Wu CS, et al. Lymphopaenia, anti-Ro/ anti-RNP autoantibodies, renal involvement and cyclophosphamide use correlate with increased risk of herpes zoster in patients with systemic lupus erythematosus. Acta Derm Venereol. 2013;93:314-8.

167. Zou Y, Lin M, Sheng Z, Niu S. Bortezomib and lenalidomide as front-line therapy for multiple myeloma. Leuk Lymphoma. 2014;55:2024-31.

168. Lyu SM, Byun JY, Choi YW, Choi HY. Clinical features of dermatologyconsulted inpatients - Focus on the differences between individual departments. Korean J Dermatol. 2014:52:215-21.

169. Oh SI, Oh BH, Rho JR, Kim KB, Kim JJ, Song MG, et al. Results of heart transplantation in Korea. Korean J Med. 2001;60:228-33.

170. Tzeng CH, Liu JH, Fan S, Wang SY, Wang SR, Chen KY, et al. Varicella zoster virus infection after allogeneic or autologous hemopoietic stem cell transplantation. J Formos Med Assoc. 1995;94:313-7.

171. Nakasone H, Izutsu K, Wakita S, Yamaguchi H, Muramatsu-Kida M, Usuki K Autologous stem cell transplantation with PCR-negative graft would be associated with a favorable outcome in core-binding factor acute myeloid leukemia. Biol Blood Marrow Transplant. 2008:14:1262-9.

172. Tsukamoto H, Nagafuji K, Horiuchi T, Miyamoto T, Aoki K, Takase K, et al. A phase I-II trial of autologous peripheral blood stem cell transplantation in the treatment of refractory autoimmune disease. Ann Rheum Dis. 2006;65: $508-14$

173. Jiang Z, Xiao H, Pang Y, Xiao Y. The incidence of herpes zoster after hematopoietic stem cell transplantation. Chin J Infect Chemother. 2012:12:88-91.

174. Chugh KS, Sharma SC, Singh V, Sakhuja V, Jha V, Gupta KL. Spectrum of dermatological lesions in renal allograft recipients in a tropical environment. Dermatology. 1994;188:108-12.

175. Prakash J, Singh S, Prashant GK, Kar B, Tripathi K, Singh PB. Mucocutaneous lesions in transplant recipient in a tropical country. Transplant Proc. 2004;36:2162-4.

176. Hwang EA, Kang MJ, Han SY, Park SB, Kim HC. Viral infection following kidney transplantation: long-term follow-up in a single center. Transplant Proc. 2004:36:2118-9.

177. Ko GB, Kim T, Kim SH, Choi SH, Kim YS, Woo JH, et al. Increased incidence of herpes zoster in the setting of cytomegalovirus preemptive therapy after kidney transplantation. Transpl Infect Dis. 2013;15:416-23.

178. Vinod PB, Sharma RK. Opportunistic infections (non-cytomegalovirus) in live related renal transplant recipients. Indian J Urol. 2009;25:161-8.

179. Ng P, McCluskey P, McCaughan G, Glanville A, MacDonald P, Keogh A Ocular complications of heart, lung, and liver transplantation. $\mathrm{Br} J$ Ophthalmol. 1998:82:423-8.

180. Kreis H, Oberbauer R, Campistol JM, Mathew T, Daloze P, Schena FP, et al. Long-term benefits with sirolimus-based therapy after early cyclosporine withdrawal. J Am Soc Nephrol. 2004;15:809-17. 
181. Tomonari A, Iseki T, Takahashi S, Ooi J, Takasugi K, Shimohakamada Y, et al. Varicella-zoster virus infection in adult patients after unrelated cord blood transplantation: a single institute experience in Japan. $\mathrm{Br} J$ Haematol. 2003;122:802-5.

182. Onozawa M, Hashino S, Haseyama Y, Hirayama Y, lizuka S, Ishida T, et al. Incidence and risk of postherpetic neuralgia after varicella zoster virus infection in hematopoietic cell transplantation recipients: Hokkaido Hematology Study Group. Biol Blood Marrow Transplant. 2009;15:724-9.

183. Wu M, Huang F, Jiang X, Fan Z, Zhou H, Liu C, et al. Herpesvirus-associated central nervous system diseases after allogeneic hematopoietic stem cell transplantation. PLoS One. 2013;8:e77805.

184. Suzuki J, Ashizawa M, Okuda S, Wada H, Sakamoto K, Terasako K, et al. Varicella zoster virus meningoencephalitis after allogeneic hematopoietic stem cell transplantation. Transpl Infect Dis. 2012;14:E7-12.

185. Au WY, Hon C, Cheng VCC, Ma ESK. Concomitant zoster myelitis and cerebra leukemia relapse after stem cell transplantation. Ann Hematol. 2005;84:59-60.

186. Fukuno K, Tomonari A, Takahashi S, Ooi J, Takasugi K, Tsukada N, et al. Varicella-zoster virus encephalitis in a patient undergoing unrelated cord blood transplantation for myelodysplastic syndrome-overt leukemia. Int J Hematol. 2006;84:79-82.

187. Kang EH, Chung MP, Kang SJ, An CH, Ahn JW, Han J, Lee. Clinical features and treatment response in 18 cases with idiopathic nonspecific interstitial pneumonia. Tuberc Respir Dis. 2000;48:530-41.

188. Ozono Y, Harada T, Yamaguchi K, Taura K, Hara K, Taguchi T. Nephrotic syndrome in the elderly-clinicopathological study. Nihon Jinzo Gakkai Shi. 1994;36:44-50

189. Satoh N, Abe T, Nakajima A, Sakuragi S. Recurrent varicella-zoster virus retinitis in a patient treated with systemic corticosteroids. Ocul Immunol Inflamm. 1998;6:185-8

190. Xiao X, Lu Y, Su H, Zhong K, Chen X, Da Y, et al. Clinical features and treatment of angioimmunoblastic T-cell lymphoma. Chin J Clin Oncol. 2011;38:1103-6.

191. Usami E, Kimura M, Matsuoka T, Okada K, Nakao T, Yoshimura T, et al. The frequency and risk factor of herpes zoster infection in non-Hodgkin's lymphoma patients. Jpn J Cancer Chemother. 2011;38:243-7.

192. Mills AK, Taylor KM, Wright SJ, Bunce LH, Bashford J, White K, et al. Sustained responses following alternating chlorodeoxyadenosine (2CDA) and VAC regimen in poor-risk de-novo follicular non-hodgkin's lymphoma (NHL). In: Blood 2000;96(11) Part II: The 2nd Annual Scientific Meeting of the Haematology Society of Australia and New Zealand, Perth, WA, 25-28 July 2000. p. 243b.

193. Au WY, Kwong YL. Frequent varicella zoster reactivation associated with therapeutic use of arsenic trioxide: portents of an old scourge. J Am Acad Dermatol. 2005;53:890-2

194. Zhang Q, Mu LJ, Wang XB, Li L, Kang ZJ, Yan JS. Clinical analysis of hematologic disorders complicated with herpes zoster after treating with arsenic trioxide. J Leuk Lymphoma. 2011;20:412-4.

195. Yamakura M, Tsuda K, Ugai T, Sugihara H, Nisihida Y, Takeuchi M, et al. High frequency of varicella zoster virus reactivation associated with the use of arsenic trioxide in patients with acute promyelocytic leukemia. Acta Haematol. 2014;131:76-7.

196. Au WY, Kumana CR, Lee HK, Lin SY, Liu H, Yeung DY, et al. Oral arsenic trioxide-based maintenance regimens for first complete remission of acute promyelocytic leukemia: a 10-year follow-up study. Blood. 2011;118:6535-43.

197. Chan AYK, Hooi LS. Outcome of 85 lupus nephritis patients treated with intravenous clophosphamide: A single centre 10 year experience. Med J Malays. 2000;55:14-20.

198. Chan TM, Li FK, Wong RW, Wong KL, Chan KW, Cheng IK. Sequential therapy for diffuse proliferative and membranous lupus nephritis: cyclophosphamide and prednisolone followed by azathioprine and prednisolone. Nephron. 1995;71:321-7.

199. Chan TM, Li FK, Hao WK, Chan KW, Lui SL, Tang S, et al. Treatment of membranous lupus nephritis with nephrotic syndrome by sequential immunosuppression. Lupus. 1999:8:545-51.

200. Mok CC, Ho CT, Siu YP, Chan KW, Kwan TH, Lau CS, et al. Treatment of diffuse proliferative lupus glomerulonephritis: a comparison of two cyclophosphamide-containing regimens. Am J Kidney Dis. 2001;38:256-64.

201. Liu G, Chen Y, Zuo C, Xie Q, Wang Z, Wang L, et al. Study on bolus cyclosphamide treatment for 64 cases of lupus nephritis. J West China Univ Med Sci. 2001;32:129-130,139.

202. Mok CC, Ying KY, Mak A, To CH, Szeto ML. Outcome of protein-losing gastroenteropathy in systemic lupus erythematosus treated with prednisolone and azathioprine. Rheumatology (Oxford). 2006;45:425-9.
203. Kim JH, Cheon JH, Kim WH. The frequency and the course of the adverse effects of azathioprine/6-mercaptopurine treatment in patients with inflammatory bowel disease. Korean J Gastroenterol. 2008;51:291-7.

204. Eisen HJ, Kobashigawa J, Keogh A, Bourge R, Renlund D, Mentzer R, et al. Three-year results of a randomized, double-blind, controlled trial of mycophenolate mofetil versus azathioprine in cardiac transplant recipients. J Heart Lung Transplant. 2005;24:517-25.

205. Zeher M, Doria A, Lan J, Aroca G, Jayne D, Boletis I, et al. Efficacy and safety of enteric-coated mycophenolate sodium in combination with two glucocorticoid regimens for the treatment of active lupus nephritis. Lupus. 2011:20:1484-93.

206. Hu W, Liu C, Xie H, Chen H, Liu Z, Li L. Mycophenolate mofetil versus cyclophosphamide for inducing remission of ANCA vasculitis with moderate renal involvement. Nephrol Dial Transplant. 2008;23:1307-12.

207. Kim YS, Moon JI, Kim SI, Park K. Clear benefit of mycophenolate mofetil-based triple therapy in reducing the incidence of acute rejection after living donor renal transplantations. Transplantation. 1999;68:578-81

208. Lu F, Tu $Y$, Peng $X$, Wang $L$, Wang $H$, Sun $Z$, et al. A prospective multicentre study of mycophenolate mofetil combined with prednisolone as induction therapy in 213 patients with active lupus nephritis. Lupus. 2008;17:622-9.

209. Hegde S, Annamalai R, Biswas J. Extensive herpes zoster involvement following mycophenolate mofetil therapy for sarcoidosis. J Ophthalmic Inflamm Infect. 2012;2:47-8.

210. Satoh S, Tada H, Murakami M, Tsuchiya N, Inoue T, Togashi H, et al. The influence of mycophenolate mofetil versus azathioprine and mycophenolic acid pharmacokinetics on the incidence of acute rejection and infectious complications after renal transplantation. Transplant Proc. 2005;37:1751-3.

211. Yap DY, Yu X, Chen XM, Lu F, Chen N, Li XW, et al. Pilot 24 month study to compare mycophenolate mofetil and tacrolimus in the treatment of membranous lupus nephritis with nephrotic syndrome. Nephrology (Carlton). 2012;17:352-7.

212. Mak SK, Lo KY, Lo MW, Chan SF, Tong GM, Wong PN, et al. Efficacy of enteric-coated mycophenolate sodium in patients with active lupus nephritis. Nephrology (Carlton). 2008;13:331-6.

213. Li L, Wang H, Lin S, et al. Mycophenolate mofetil treatment for diffuse proliferative lupus nephritis: a multicenter clinical trial in China. Zhonghua Nei Ke Za Zhi. 2002;41:476-9.

214. Xie QX, Han CX, Li JY, Lin XC, Zhao L, Huang HW, et al. Application of lowdosage mycophenolate mofetil in living renal transplantation of lineal consanguinity. J Clin Rehab Tissue Eng Res. 2009;13:924-6.

215. Jenks KA, Stamp LK, O'Donnell JL, Savage RL, Chapman PT. Leflunomideassociated infections in rheumatoid arthritis. J Rheumatol. 2007;34:2201-3.

216. Yoo HG, Yu HM, Jun JB, Jeon HS, Yoo WH. Risk factors of severe infections in patients with rheumatoid arthritis treated with leflunomide. Mod Rheumatol. 2013:23:709-15.

217. Cui TG, Hou FF, Ni ZH, Chen XM, Zhang FS, Zhu TY, et al. Treatment of proliferative lupus nephritis with leflunomide and steroid: a prospective multi-center controlled clinical trial. Zhonghua Nei Ke Za Zhi. 2005;44: 672-6.

218. Muir VJ, Plosker GL. Cladribine tablets: in relapsing-remitting multiple sclerosis. CNS Drugs. 2011;25:239-49.

219. Kim SJ, Moon JH, Kim H, Kim JS, Hwang YY, Intragumtornchai T, et al. Non-bacterial infections in Asian patients treated with alemtuzumab: A retrospective study of the Asian Lymphoma Study Group. Leuk Lymphoma. 2012;53:1515-24.

220. Chung BH, Kim Y, Jeong HS, Hong YA, Choi BS, Park CW, et al. Clinical outcome in patients with chronic antibody-mediated rejection treated with and without rituximab and intravenous immunoglobulin combination therapy. Transpl Immunol. 2014;31:140-4.

221. Ito K, Okamoto M, Maruyama F, Handa K, Yamamoto $Y$, Watanabe M, et al. Alteration in antibody-mediated immunity in patients with rituximabcombined chemotherapy and incidence of herpes zoster. Gan To Kagaku Ryoho. 2010;37:99-102.

222. Kurokawa T, Hase M, Tokuman N, Yoshida T. Immune reconstitution of Bcell lymphoma patients receiving CHOP-based chemotherapy containing rituximab. Hematol Oncol. 2011;29:5-9.

223. Lee SD, Kim SH, Kong SY, Kim YK, Lee SA, Park SJ. ABO-incompatible living donor liver transplantation without graft local infusion and splenectomy. HPB (Oxford). 2014;16:807-13. 
224. Tu MF, Zheng W, Lin NJ, Zhang YT, Wang XP, Song YQ, et al. Efficacy and safety of fludarabine-based combination chemotherapy in patients with previously untreated follicular non-Hodgkin's lymphoma. Tumor. 2011;31:58-63.

225. Furie R, Nicholls K, Cheng TT, Houssiau F, Burgos-Vargas R, Chen SL, et al. Efficacy and safety of abatacept in lupus nephritis: A twelve-month, randomized, double-blind study. Arthritis Rheum. 2014;66:379-89.

226. Lee EB, Fleischmann R, Hall S, Wilkinson B, Bradley JD, Gruben D, et al. Tofacitinib versus methotrexate in rheumatoid arthritis. N Engl J Med. 2014; 370:2377-86.

227. Winthrop KL, Yamanaka H, Valdez H, Mortensen E, Chew R, Krishnaswami S, et al. Herpes zoster and tofacitinib therapy in patients with rheumatoid arthritis. Arthritis Rheum. 2014;66:2675-84.

228. Wang X, Zhao J, Zhu S, Xia B. Herpes zoster in Crohn's disease during treatment with infliximab. Eur J Gastroenterol Hepatol. 2014;26:237-9.

229. Choi KD, Song HJ, Kim JS, Jung HC, Song IS. Efficacy and safety of treatment with infliximab in Crohn's disease-the experience of single center in Korea. Korean J Gastroenterol. 2005;46:48-55.

230. Kim YJ, Kim JW, Lee CK, Park HJ, Shim JJ, Jang JY, et al. Clinical outcome of treatment with infliximab in Crohn's disease: a single-center experience. Korean J Gastroenterol. 2013:61:270-8.

231. Yi YS, Chung JS, Song MK, Shin HJ, Seol YM, Choi YJ, et al. The risk factors for herpes zoster in bortezomib treatment in patients with multiple myeloma. Korean J Hematol. 2010;45:188-92.

232. Kim SJ, Kim K, Kim BS, Lee HJ, Kim H, Lee NR, et al. Bortezomib and the increased incidence of herpes zoster in patients with multiple myeloma. Clin Lymphoma Myeloma. 2008:8:237-40.

233. Kim MG, Kim YJ, Kwon HY, Park HC, Koo TY, Jeong JC, et al. Outcomes of combination therapy for chronic antibody-mediated rejection in renal transplantation. Nephrology (Carlton). 2013;18:820-6.

234. Tong Y, Qian J, Li Y, Meng H, Jin J. The high incidence of varicella herpes zoster with the use of bortezomib in 10 patients. Am J Hematol. 2007;82:403-4.

235. Zhong YP, Chen SL, Li X, Hu Y, Zhang JJ. Bortezomib combined with other drugs for treating 60 cases of multiple myeloma. Zhongguo Shi Yan Xue Ye Xue Za Zhi. 2009;17:214-7.

236. Khalafallah AA, Woodgate M, Koshy K, Patrick A. Ophthalmic manifestations of herpes zoster virus in patients with multiple myeloma following bone marrow transplantation. BMJ Case Rep. 2013; doi:10.1136/bcr-2012-007625.

237. Zhang YQ, Liang $R$, Bai $Q X$, Zhang $T$, Yang $L$, Wang $Y W$, et al. PAD regimen for relapsed or refractory patients with multiple myeloma. Zhonghua Xue Ye Xue Za Zhi. 2009:30:260-3.

238. Muta T, Nakanishi H, Yasunaga M, Senba S, Murakami H, Kan S, et al. Safety evaluation of bortezomib in multiple myeloma patients with severe renal failure. Jpn J Cancer Chemother. 2011;38:237-41.

239. Li CM, Lu H, Wu HX, Qiu HX, Qian SX, Xu W, et al. Therapeutic efficacy of bortezomib-based chemotherapy on 40 patients with multiple myeloma. Zhongguo Shi Yan Xue Ye Xue Za Zhi. 2010;18:1511-4.

240. Yang G, Chen W, Wu Y. Bortezomib, dexamethasone plus thalidomide for treatment of newly diagnosed multiple myeloma patients with or without renal impairment. Chin J Cancer Res. 2013;25:155-60.

241. He J, Yang L, Han X, Zheng G, Zheng W, Wei G, et al. The choice of regimens based on bortezomib for patients with newly diagnosed multiple myeloma. PLoS One. 2014;9:e99174

242. Huang B, Li J, Xu X, Zheng D, Zhou Z, Liu J. Successful treatment of renal light chain (AL) amyloidosis with bortezomib and dexamethasone (VD). Pathol Biol (Paris). 2015;63:17-20.

243. Zhang Y, Shi B, Chen X, Xia Y, Ye L, Liu L, et al. Bortezomib combined with doxorubicin and dexamethasone for patients with refractory senile mantle cell lymphoma. Chin J Clin Oncol. 2011;38:1092-4.

244. Zhong YP, Chen SL. Effect of treatment by bortezomib with other drugs for the refractory multiple myeloma. J Leuk Lymphoma. 2009;18:538-40.

245. Zhu JJ, Li L, Ye XJ, He JS, Cai Z. Bortezomib combined with epirubicin and dexamethasone in treatment of multiple myeloma. J Pract Oncol. 2013;28:520-2.

246. Ohguchi H, Sugawara T, Ishikawa I, Okuda M, Tomiya Y, Yamamoto J, et al. A retrospective analysis of bortezomib therapy for Japanese patients with relapsed or refractory multiple myeloma: beta2-microglobulin associated with time to progression. Int J Hematol. 2009;89:342-7.

247. Coiffier B, Osmanov EA, Hong X, Scheliga A, Mayer J, Offner F, et al. Bortezomib plus rituximab versus rituximab alone in patients with relapsed, rituximab-naive or rituximab-sensitive, follicular lymphoma: a randomised phase 3 trial. Lancet Oncol. 2011;12:773-84.
248. Yang GZ, Chen WM, Shen M, Fu LN, Jiang L, Gao W, et al. Sequential therapy of BTD and MPT regimen for the newly-diagnosed multiple myeloma patients no eligible for bone marrow transplantation. J Leuk Lymphoma. 2011;20:350-2.

249. Zhai YP, Liu HN, Yu YP, Zhou XG, Song P, Li F, et al. Treatment of primary systemic amyloidosis with the combination of bortezomib and dexamethasone. Zhonghua Xue Ye Xue Za Zhi. 2010;31:319-22.

250. Gu HT, Shu MM, Gao GX, Dong BX, Liang R, Yang L, et al. Efficacy comparison between standard and reduced doses of bortezomib combined with adriamycin and dexamethasone in the treatment of patients with multiple myeloma. Zhonghua Xue Ye Xue Za Zhi. 2013;34:622-5.

251. Zhao Y, Dou LP, Wang SH, Bo J, Wang QS, Huang WR, et al. The efficacy and safety of PAD and VAD regimens for untreated multiple myeloma. Zhonghua Nei Ke Za Zhi. 2010;49:762-4.

252. Hung MH, Kuo JR, Huang KF, Wang WC. Sacral herpes zoster presenting as sciatica. CMAJ. 2010;182:E534.

253. Sachdeva S, Prasher P. Herpes zoster following saphenous venectomy for coronary bypass surgery. J Card Surg. 2010;25:28-9.

254. Basavaraj S, Prakash BG, Shetty TS, Sandhya D, Kallada S. Delayed facial nerve weakness after intact canal wall tympanomastoidectomy. Otol Neurotol. 2014;35:1003-6.

255. Lee MR, Ryman W. Herpes zoster following cryosurgery. Australas J Dermatol. 2005:46:42-3.

256. Brandon EL, Akers J, Rapeport D. Development of bilateral herpes zoster following thoracoscopic splanchnicectomy. Anaesth Intensive Care. 2006;34:382-3.

257. Park KS, Yoon TR, Kim SK, Park HW, Song EK. Acute postoperative herpes zoster with a sciatic nerve distribution after total joint arthroplasty of the ipsilateral hip and contralateral knee. J Arthroplasty. 2010;25:497. e11-5.

258. Choi HJ, Kim JH, Lee YM. Herpes zoster developing within recent subciliary incision scar. J Craniofac Surg. 2012;23:930-1.

259. Lin KC, Wang CC, Wang KY, Liao YC, Kuo JR. Reactivation of herpes zoster along the trigeminal nerve with intractable pain after facial trauma: a case report and literature review. BMJ Case Rep. 2009; doi:10.1136/bcr.07.2008.0525.

260. Furuta Y, Ohtani F, Fukuda S, Inuyama Y, Nagashima K. Reactivation of varicella-zoster virus in delayed facial palsy after dental treatment and orofacial surgery. J Med Virol. 2000;62:42-5.

261. Furukawa K, Sakoh M, Kumon Y, Teraoka M, Ohta S, Ohue S, et al. Delayed facial palsy after microvascular decompression for hemifacial spasm due to reactivation of varicella-zoster virus. No Shinkei Geka. 2003;31:899-902.

262. Baba T, Yamasaki A, Miyake A, Funakoshi T, Yakura K, Miyazaki D, et al. Varicella zoster virus iridocyclitis following macular hole surgery in a case of von Hippel-Lindau disease. Jpn J Clin Ophthalmol. 2011;65:333-7.

263. Fujitani A, Hayasaka S. Herpes zoster ophthalmicus after cataract surgery in a patient with a history of gastric cancer. Ann Ophthalmol Glaucoma. 1997;29:57-8.

264. Koide C. Multiple cranial nerve dysfunction after uncomplicated neurovascular decompression for hemifacial spasm. Otolaryngol Head Neck Surg Tokyo. 1997;69:72-5.

265. Tsukahara T, Huang J, Oyamada T, Uchio E. Herpetic corneal endotheliitis in a case after deep lamellar keratoplasty for bacterial keratitis. Jpn J Clin Ophthalmol. 2010;64:1287-91.

266. Gyo K, Honda N. Delayed facial palsy after middle-ear surgery due to reactivation of varicella-zoster virus. J Laryngol Otol. 1999;113:914-5.

267. Kohjitani A, Miyawaki T, Kasuya K, Shimada M. Sympathetic activitymediated neuropathic facial pain following simple tooth extraction: a case report. Cranio. 2002;20:135-8.

268. Walland MJ. Presumed ophthalmic Herpes zoster after contralateral cataract extraction. Acta Ophthalmol Scand. 1995;73:83-5.

269. Kam AC, Dan NG, Maclean J, Higgins D. Zoster related multiple cranial nerve palsies: an unusual complication following percutaneous balloon compression for trigeminal neuralgia. J Clin Neurosci. 1999;6:261-4.

270. Makkar JK, Singh NP, Rastogi V. Herpes zoster: Are selective nerve root injections the treatment or the cause? Pain Phys. 2010;13:196-8.

271. Oh IH, Choi SK, Park BJ, Kim TS, Rhee BA, Lim YJ. The treatment outcome of elderly patients with idiopathic trigeminal neuralgia : Micro-vascular decompression versus gamma knife radiosurgery. J Korean Neurosurg Soc. 2008:44:199-204.

272. Chen YH, Rau RH, Keller JJ, Lin HC. Possible effects of anaesthetic management on the $1 \mathrm{yr}$ followed-up risk of herpes zoster after Caesarean deliveries. $\mathrm{Br} J$ Anaesth. 2012;108:278-82. 
273. Terao M, Yamamoto T, Umeda J, Shirabe H. Drug induced herpes zoster (Do statin induce herpes zoster?). Skin Res. 2005;4:335-8.

274. Chung SD, Tsai MC, Liu SP, Lin HC, Kang JH. Herpes zoster is associated with prior statin use: a population-based case-control study. PLoS One. 2014;9:e111268.

275. Kano Y, Horie C, Inaoka M, Tadashi I, Mizukawa Y, Shiohara T. Herpes zoster in patients with drug-induced hypersensitivity syndrome/DRESS. Acta Derm-Venereol. 2012;92:206-7.

276. Follezou JY, Lan NY, Lien TX, Lafon ME, Tram LT, Hung PV, et al. Clinical and biological characteristics of human immunodeficiency virus- infected and uninfected intravascular drug users in Ho Chi Minh City, Vietnam. Am J Trop Med Hyg. 1999;61:420-4.

277. Sivayathorn A, Srihra B, Leesanguankul W. Prevalence of skin disease in patients infected with human immunodeficiency virus in Bangkok, Thailand. Ann Acad Med Singapore. 1995:24:528-33.

278. Supanaranond W, Desakorn V, Sitakalin C, Naing N, Chirachankul P. Cutaneous manifestations in HIV positive patients. Southeast Asian J Trop Med Public Health. 2001;32:171-6.

279. Li ZH, Hua YH. Clinical analysis of skin and mucosa manifestations in 130 patients with HIV. J Clin Dermatol. 2013;42:720-2.

280. Wiwanitkit V. Prevalence of dermatological disorders in Thai HIV-infected patients correlated with different CD4 lymphocyte count statuses: a note on 120 cases. Int J Dermatol. 2004:43:265-8.

281. Sungkanuparph $S$, Vibhagool A, Mootsikapun $P$, Chetchotisakd $P$, Tansuphaswaswadikul S, Bowonwatanuwong C. Opportunistic infections after the initiation of highly active antiretroviral therapy in advanced AIDS patients in an area with a high prevalence of tuberculosis. AIDS. 2003;17: 2129-31.

282. Tzung TY, Yang CY, Chao SC, Lee JY. Cutaneous manifestations of human immunodeficiency virus infection in Taiwan. Kaohsiung J Med Sci. 2004;20:216-24.

283. Dwiyana RF, Rowawi $R$, Lestari M, Alisjahbana B, van der Ven AJ, Djajakusumah TS. Skin disorders in HIV-infected patients from West Java. Acta Med Indones. 2009;41 Suppl 1:18-22.

284. Wong KH, Lee SS, Lo YC, Li PC, Ho HF, Sitt WH, et al. Profile of opportunistic infections among HIV-1 infected people in Hong Kong. Zhonghua Yi Xue Za Zhi (Taipei). 1995;55:127-36.

285. Huang XJ, Li HY, Chen DX, Wang XC, Li ZC, Wu YS, et al. Clinical analysis of skin lesions in 796 Chinese HIV- positive patients. Acta Derm Venereol. 2011;91:552-6.

286. Chen XC, Lu XJ, Ye H, Gao YY. Clinical analysis of 109 HIV/AIDS patients. Chin J Infect Chemother. 2008;8:183-6.

287. Oh MD, Park SW, Kim HB, Kim US, Kim NJ, Choi HJ, et al. Spectrum of opportunistic infections and malignancies in patients with human immunodeficiency virus infection in South Korea. Clin Infect Dis. 1999; 29:1524-8.

288. Wani KA. Clinical profile of HIV/Aids patients in Srinagar, Kashmir, India. Int J Collab Res Intern Med Public Health. 2012;4:1703-12.

289. Wadia RS, Pujari SN, Kothari S, Udhar M, Kulkarni S, Bhagat S, et al, Neurological Manifestations of HIV Disease. J Assoc Physicians India. 2001; 49:343-8.

290. Shobhana A, Guha SK, Neogi DK. Mucocutaneous manifestations of HIV infection. Indian J Dermatol Venereol Leprol. 2004;70:82-6.

291. Arora U, Chopra S, Jindal N. HIV infection in families in and around Amritsar. J Indian Acad Clin Med. 2008;9:184-7.

292. Ghate M, Deshpande S, Tripathy S, Nene M, Gedam P, Godbole S, et al. Incidence of common opportunistic infections in HIV-infected individuals in Pune, India: analysis by stages of immunosuppression represented by CD4 counts. Int J Infect Dis. 2009;13:e1-8.

293. Solomon SS, Hawcroft CS, Narasimhan P, Subbaraman R, Srikrishnan AK Cecelia AJ, et al. Comorbidities among HIV-infected injection drug users in Chennai, India. Indian J Med Res. 2008;127:447-52.

294. Jindal N, Aggarwal A, Kaur S. HIV seroprevalence and HIV associated dermatoses among patients presenting with skin and mucocutaneous disorders. Indian J Dermatol Venereol Leprol. 2009;75:283-6.

295. Kar HK, Narayan R, Gautam RK, Jain RK, Doda V, Sengupta D, et al. Mucocutaneous disorders in Hiv positive patients. Indian J Dermatol Venereol Leprol. 1996;62:283-5.

296. Srirangaraj S, Venkatesha D. Opportunistic infections in relation to antiretroviral status among AIDS patients from south India. Indian J Med Microbiol. 2011;29:395-400.
297. Shahapur PR, Bidri RC. Recent trends in the spectrum of opportunistic infections in human immunodeficiency virus infected individuals on antiretroviral therapy in South India. J Nat Sci Biol Med. 2014;5:392-6.

298. Song JY, Lee JS, Jung HW, Choi HJ, Lee JS, Eom JS, et al. Herpes zoster among HIV-infected patients in the highly active antiretroviral therapy era: Korean HIV cohort study. J Acquired Immune Defic Syndr. 2010;53: 417-9.

299. Kim JM, Cho GJ, Hong SK, Chung JS, Jang KH, Kim CO, et al. Epidemiologic and clinical features of HIV infection/AIDS in Koreans. Korean J Med. 2001; 61:355-64.

300. Nam TS, Seo KS, Lee Kl, Kim YS, Hong JH, Kim GH, et al. The clinical study of hematoimmunologic features and opportunistic infections of patients with AIDS. Korean J Med. 1997:52:15-23.

301. Choe KW, Oh MD, Park SW, Kim HB, Kim US, Kang SW, et al. Opportunistic infections and malignancies in 173 patients with HIV infection. Korean J Infect Dis. 1998;30:507-15.

302. McNulty A, Li Y, Radtke U, Kaldor J, Rohrsheim R, Cooper DA, Donovan B. Herpes zoster and the stage and prognosis of HIV-1 infection. Genitourin Med. 1997;73:467-70.

303. Hung CC, Hsiao CF, Wang JL, Chen MY, Hsieh SM, Sheng WH, et al. Herpes zoster in HIV-1-infected patients in the era of highly active antiretroviral therapy: a prospective observational study. Int J STD AIDS. 2005;16:673-6.

304. Chopra S, Arora U. Skin and mucocutaneous manifestations: Useful clinical predictors of HIV/AIDS. J Clin Diagn Res. 2012;6:1695-8.

305. Kore SD, Kanwar AJ, Vinay K, Wanchu A. Pattern of mucocutaneous manifestations in human immunodeficiency virus-positive patients in North India. Indian J Sex Transm Dis. 2013:34:19-24.

306. Mali RJ, Wankhade AB, Ghadage DP, Muley VA, Bhore AV. Cutaneous manifestations in HIV infected patients in rural area. J Pure Appl Microbiol. 2012;6:467-70.

307. Panda S, Sarkar S, Mandal BK, Singh TB, Singh KL, Mitra DK, et al. Epidemic of herpes zoster following HIV epidemic in Manipur, India. J Infect. 1994;28:167-73.

308. Panda S, Kamei G, Pamei M, Sarkar S, Sarkar K, Singh ND, et al. Clinical features of HIV infection in drug users of Manipur. Natl Med J India. 1994;7: 267-9.

309. Antwal M, Gurjar R, Chidrawar S, Pawar J, Gaikwad S, Panchal N, et al. Clinical profile of HIV infected patients attending a HIV referral clinic in Pune. India Indian J Med Res. 2014;140:271-7.

310. Lloyd A. HIV infection and AIDS. P N G Med J. 1996;39:174-80.

311. Satishchandra P, Nalini A, Gourie-Devi M, Khanna N, Santosh V, Ravi V, et al. Profile of neurologic disorders associated with HIV/AIDS from Bangalore, south India (1989-96). Indian J Med Res. 2000;111:14-23.

312. Srikanth KP, Vijayakumar S, Aparna, Mallikarjun. A hospital based cross sectional study of mucocutaneous manifestations in the HIV infected. Int J Collab Res Intern Med Public Health. 2010:2:50-78.

313. Fernandes MS, Bhat RM. Spectrum of mucocutaneous manifestations in human immunodeficiency virus-infected patients and its correlation with CD4 lymphocyte count. Int J STD AIDS. 2015;26:414-9.

314. Singh HR, Singh NG, Singh TB. Estimation of CD4+ and CD8+ T-lymphocytes in human immunodeficiency virus infection and acquired immunodeficiency syndrome patients in Manipur. Indian J Med Microbiol. 2007:25:126-32.

315. Price P, Murdoch DM, Agarwal U, Lewin SR, Elliott JH, French MA. Immune restoration diseases reflect diverse immunopathological mechanisms. Clin Microbiol Rev. 2009;22:651-63.

316. Choi WR, Seo MC, Sung KU, Lee HE, Yoon HJ. Herpes zoster immune reconstitution inflammatory syndrome in a HIV-infected patient: Case report and literature review. Infect Chemother. 2012:44:391-4.

317. Handa S, Narang T, Wanchu A. Dermatologic immune restoration syndrome: report of five cases from a tertiary care center in north India. J Cutan Med Surg. 2008;12:126-32.

318. Sharma A, Makrandi S, Modi M, Sharma A, Marfatia Y. Immune reconstitution inflammatory syndrome. Indian J Dermatol Venereol Leprol. 2008;74:619-21.

319. Terada K, Yoshihiro K, Kawano S, Morita T. Incidence of herpes zoster in pediatricians and family practitioners Estimation of efficacy of varicella vaccine for protection against herpes zoster in the elderly. Kawasaki Med J. 1994;20:99-102.

320. Mittal RR. Infectivity of varicella and herpes zoster. Indian J Dermatol Venereol Leprol. 1996;62:196-7. 
321. Chandak SO, Pandilwar PK. Epidemic of herpes zoster in a family. J Oral Maxillofacial Surg Med Pathol. 2012;24:42-4.

322. Suzuki K, Yoshikawa T, Tomitaka A, Matsunaga K, Asano Y. Detection of aerosolized varicella-zoster virus DNA in patients with localized herpes zoster. J Infect Dis. 2004;189:1009-12.

323. Suzuki K, Yoshikawa T, Tomitaka A, Suzuki K, Matsunaga K, Asano Y. Detection of varicella-zoster virus DNA in throat swabs of patients with herpes zoster and on air purifier filters. J Med Virol. 2002;66:567-70.

324. Yoshikawa T, Ihira M, Suzuki K, Suga S, Tomitaka A, Ueda H, et al. Rapid contamination of the environments with varicella-zoster virus DNA from a patient with herpes zoster. J Med Virol. 2001;63:64-6.

325. Zhai JX, Ji J, Li M. Cutaneous tuberculosis complicated with squamous cell carcinoma. J Clin Dermatol. 2010;39:713-5.

326. Kansal HM, Goel S. Cutaneous manifestations in cases of pulmonary tuberculosis: A clinical profile. J Indian Acad Clin Med. 2013;14:284-6.

327. Kulkarni AG, Brid NS. Images in clinical medicine. Herpes zoster. N Engl J Med. 1995;332:1684.

328. Regunath H, Shivashankara KN, Sundeep KB, Bhaskar AP. Reactivation of Herpes zoster in an adult with Plasmodium infection. J Vector Borne Dis. 2008:45:251-3

329. Park B, Yun SJ, Lee JB, Lee SC, Won YH, Kim SJ. Analysis of dermatoses in pregnant patients. Korean J Dermatol. 2013;51:249-57.

330. Kim WJ, Kim JY, Lee WJ, Lee SJ, Kim DW, Ko HC, et al. Investigation of the clinical manifestations of herpes zoster during pregnancy and its impact on the perinatal outcome. Korean J Dermatol. 2010;48:941-7.

331. Thami GP, Kanwar AJ. Herpes zoster during pregnancy near term: to treat or not to treat? Aust N Z J Obstet Gynaecol. 1999;39:371.

332. Tsai YG, Lai JH, Kuo SY, Chen HC, Chang DM. Thymoma and hypogammaglobulinemia (Good's syndrome): a case report. J Microbiol Immunol Infect. 2005;38:218-20.

333. Chen JY, Chang CY, Lin YS, Hu ML. Nutritional factors in herpes zoster, postherpetic neuralgia, and zoster vaccination. Popul Health Manag. 2012;15:391-7.

334. Chao CT, Lee SY, Yang WS, Yen CJ, Chiang CK, Huang JW, et al. Serum vitamin $\mathrm{D}$ levels are positively associated with varicella zoster immunity in chronic dialysis patients. Sci Rep. 2014:4:7371.

335. Chao CT, Lai CF, Huang JW. Risk factors for herpes zoster reactivation in maintenance hemodialysis patients. Eur J Intern Med. 2012;23:711-5.

336. Chi CY, Chu CC, Liu JP, Lin CH, Ho MW, Lo WJ, et al. Anti-IFN- $\gamma$ autoantibodies in adults with disseminated nontuberculous mycobacterial infections are associated with $\mathrm{HLA}_{\mathrm{L}-\mathrm{DRB}{ }^{*} 16: 02 \text { and } \mathrm{HLA}-\mathrm{DQB} 1{ }^{*} 05: 02}$ and the reactivation of latent varicella-zoster virus infection. Blood. 2013;121:1357-66.

337. Cho JW, Shin DH, Lee KS. Polymorphism of the IL-10 gene is associated with susceptibility to herpes zoster in Korea. J Dermatol Sci. 2007:45:213-5.

338. Park SJ, Cho JW, Lee KS. Single nucleotide polymorphisms of interleukin-10 promoter gene in Korean herpes zoster patients. Korean J Dermatol. 2006; 44:1325-31.

339. Yuan LL, Wang LX, Xie YM, Yang W, Yang ZX, Zhuang Y, et al. Analysis on clinical features and treatment of herpes zoster patients hospitalized in real world. Zhongguo Zhongyao Zazhi. 2014;39:3469-73.

340. Oh HM, Ho AY, Chew SK, Monteiro EH. Clinical presentation of herpes zoster in a Singapore hospital. Singapore Med J. 1997;38:471-4.

341. Vikrant S. Long-term clinical outcomes of peritoneal dialysis patients: 9-year experience of a single center from north India. Perit Dial Int. 2014;34:426-33.

342. Sato $T$, Inoue $T$, Endo $K$, Watanabe $Y$, Kikuta $T$, Tsuda M, et al. End-stage renal disease (ESRD) contributes to the increasing prevalence of herpes zoster. NDT Plus. 2009;2:263-4.

343. Muraya Y. Clinical and immunological evaluation of infection in patients on hemodialysis. J Infect Chemother. 1996;2:247-53.

344. Iwamoto M, Kamimura T, Nagashima T, Kamata Y, Aoki Y, Onishi S, et al. Healthcare-associated infections in rheumatology in Japan. Rheumatol Int. 2012;32:801-4

345. Nishimaki T, Watanabe K, Satho Y, Okubo M, Kaise S, Miyata M, et al. Viral, fungal and mycobacterial infections in patients with systemic lupus erythematosus. Jpn J Rheumatol. 1999;9:45-54.

346. Ishikawa O, Abe M, Miyachi Y. Herpes zoster in Japanese patients with systemic lupus erythematosus. Clin Exp Dermatol. 1999;24:327-8.

347. Naganuma M, Kunisaki R, Yoshimura N, Takeuchi Y, Watanabe M. A prospective analysis of the incidence of and risk factors for opportunistic infections in patients with inflammatory bowel disease. J Gastroenterol. 2013;48:595-600.
348. Binitha MP, Sarita SP, Manju M. Photoletter to the editor: Squamous cell carcinoma associated with and masquerading as molluscum contagiosum. J Dermatol Case Rep. 2013;7:103-5.

349. Rajagopal R, Arora PN, Ramasastry CV, Kar PK. Skin changes in internal malignancy. Indian J Dermatol Venereol Leprol. 2004;70:221-5.

350. Ayyamperumal A, Tharini G, Ravindran V, Parveen B. Cutaneous manifestations of internal malignancy. Indian J Dermatol. 2012;57:260-4.

351. Okamoto S, Hata A, Sadaoka K, Yamanishi K, Mori Y. Comparison of varicellazoster virus-specific immunity of patients with diabetes mellitus and healthy individuals. J Infect Dis. 2009;200:1606-10.

352. Mahajan S, Koranne R, Sharma S. Cutaneous manifestation of diabetes melitus. Indian J Dermatol Venereol Leprol. 2003;69:105-8.

353. Yang YW, Chen YH, Lin HW. Risk of herpes zoster among patients with psychiatric diseases: a population-based study. J Eur Acad Dermatol Venereol. 2011:25:447-53.

354. Lee JY, Yoon NH, Park SD. A clinical study of the nature of pain associated with herpes zoster. Korean J Dermatol. 2006:44:1298-303.

355. Yang YD, Wu JJ, Bi JJ, Lu YG, Zhu TY. Retrospective study of the characteristics of postherpetic neuralgia in 178 cases. Chin J Clin Rehab. 2005;9:23-5

356. Herr H. Prognostic factors of postherpetic neuralgia. J Korean Med Sci. 2002; 17:655-9.

357. Cho SI, Lee CH, Park GH, Park CW, Kim HO. Use of S-LANSS, a tool for screening neuropathic pain, for predicting postherpetic neuralgia in patients after acute herpes zoster events: a single-center, 12-month, prospective cohort study. J Pain. 2014;15:149-56.

358. Zhu SM, Liu YM, An ED, Chen QL. Influence of systemic immune and cytokine responses during the acute phase of zoster on the development of postherpetic neuralgia. J Zhejiang Univ Sci B. 2009;10:625-30.

359. Imafuku S, Nakayama J, Higa K, Furue M, Takahara M, Katayama I, et al. Oneyear follow-up of zoster-associated pain in 764 immunocompetent patients with acute herpes zoster treated with famciclovir (FAMILIAR study). J Eur Acad Dermatol Venereol. 2014;28:1716-22.

360. Kanbayashi Y, Onishi K, Fukazawa K, Okamoto K, Ueno H, Takagi T, et al. Predictive factors for postherpetic neuralgia using ordered logistic regression analysis. Clin J Pain. 2012;28:712-14.

361. Zhang DP, He L. Risk factors and prevention measures of postherpetic neuralgia. Chin J Clin Rehab. 2005;9:118-9.

362. Nithyanandam S, Dabir S, Stephen J, Joseph M. Eruption severity and characteristics in herpes zoster ophthalmicus: correlation with visual outcome, ocular complications, and postherpetic neuralgia. Int J Dermatol. 2009;48:484-7.

363. Nahm FS, Kim SH, Kim HS, Shin JW, Yoo SH, Yoon MH, et al. Survey on the treatment of postherpetic neuralgia in Korea; multicenter study of 1,414 patients. Korean J Pain. 2013;26:21-6.

364. Chen JY, Lan KM, Sheu MJ, Tseng SF, Weng SF, Hu ML. Peptic ulcer as a risk factor for postherpetic neuralgia in adult patients with herpes zoster. J Med Virol. 2015:87:222-9.

365. Sumiyama D, Kikkawa EF, Kita YF, Shinagawa H, Mabuchi T, Ozawa A, et al. HLA alleles are associated with postherpetic neuralgia but not with herpes zoster. Tokai J Exp Clin Med. 2008;33:150-3.

366. Sato M, Ohashi J, Tsuchiya N, Kashiwase K, Ishikawa Y, Arita H, et al. Association of HLA-A*3303-B*4403-DRB1*1302 haplotype, but not of TNFA promoter and NKp30 polymorphism, with postherpetic neuralgia (PHN) in the Japanese population. Genes Immun. 2002;3:477-81.

367. Ozawa A, Sasao Y, Iwashita K, Miyahara M, Sugai J, lizuka M, et al. HLA-A33 and -B44 and susceptibility to postherpetic neuralgia (PHN). Tissue Antigens. 1999;53:263-8.

368. Sato-Takeda M, Ihn H, Ohashi J, Tsuchiya N, Satake M, Arita H, et al. The human histocompatibility leukocyte antigen (HLA) haplotype is associated with the onset of postherpetic neuralgia after herpes zoster. Pain. 2004;110:329-36.

369. Kirizume K, Imataki O, Shintani T, Fujihara S, Waki F, Ohue Y, et al. Aggravated post-herpetic neuralgia due to bortezomib. Rinsho Ketsueki. 2008:49:331-4.

370. Choi WS, Kwon SS, Lee J, Choi SM, Lee JS, Eom JS, et al. Immunity and the burden of herpes zoster. J Med Virol. 2014;86:525-30.

371. Mehta J, Mahajan $\vee$, Khanna S. Disseminated zoster with polyneuritis cranialis and motor radiculopathy: Letter to editor. Neurol India. 2002;50:228-9.

372. Kim SH, Suh MK. The clinical features of herpes zoster ophthalmicus in inpatients. Korean J Dermatol. 2008;46:1337-43.

373. Ando $\mathrm{K}$, Kohmoto $\mathrm{H}$. Clinical features of herpes zoster ophthalmicus. Jpn J Clin Ophthalmol. 2000;54:385-7. 
374. Amaki S, Suzuki S, Shinbo R, Ando R, Oguchi Y, Shimizu H, et al. A statistical study of ocular complications of herpes zoster ophthalmicus and its prolongation factors. Nihon Ganka Gakkai Zasshi. 1995;99:289-95.

375. Yoshida M, Hayasaka S, Yamada T, Yanagisawa S, Hayasaka Y, Nakamura N, et al. Ocular findings in Japanese patients with varicella-zoster virus infection. Ophthalmologica. 2005;219:272-5.

376. Kimata N, Nakagawa $H$, Araki H. Clinical features of herpes zoster keratitis. Jpn J Clin Ophthalmol. 1996;50:1113-6.

377. Matsuda A, Tagawa Y, Abe N, Tsuda K, Matsuda H. Classification of corneal complications from varicella zoster virus. Jpn J Clin Ophthalmol. 1995;49: 1519-23.

378. McDonald EM, Patel DV, McGhee CN. A prospective study of the clinical characteristics of patients with herpes simplex and varicella zoster keratitis, presenting to a New Zealand emergency eye clinic. Cornea. 2015;34:279-84.

379. Zheng Y, Shi J. Clinical analysis of 58 cases of herpetic keratouveitis. Chin Ophthalmic Res. 2009;27:809-11.

380. Thean JH, Hall AJ, Stawell RJ. Uveitis in Herpes zoster ophthalmicus. Clin Experiment Ophthalmol. 2001;29:406-10.

381. Hanajiri M, Matsumoto T, Hatano H, Ohno S. Herpes zoster ophthalmicus without skin eruptions. Jpn J Clin Ophthalmol. 1994;48:658-60.

382. Kwok SK, Ho PCP, Chau GKO. Herpes zoster ophthalmicus - A family physician's perspective. Hong Kong Pract. 2001;23:57-62.

383. Albietz JM, Lenton LM. Late reactivation of herpes zoster keratitis results in band keratopathy. Optom Vis Sci. 2014;91:e149-55.

384. Cao L. Ophthalmic symptoms in AIDS. Int J Ophthalmol. 2009;9:393-4.

385. Nithyanandam S, Joseph M, Stephen J. Ocular complications and loss of vision due to herpes zoster ophthalmicus in patients with HIV infection and a comparison with HIV-negative patients. Int J STD AIDS. 2013;24:106-9.

386. Gupta N, Sachdev R, Sinha R, Titiyal JS, Tandon R. Herpes zoster ophthalmicus: disease spectrum in young adults. Middle East Afr J Ophthalmol. 2011;18:178-82.

387. Babu K, Kini R, Philips M, Subbakrishna DK. Clinical profile of isolated viral anterior uveitis in a South Indian patient population. Ocul Immunol Inflamm. 2014;22:356-9.

388. Ichikawa T, Sakai J, Yamauchi Y, Minoda H, Usui M. A study of 44 patients with Kirisawa type uveitis. Nihon Ganka Gakkai Zasshi. 1997;101:243-7.

389. Tan WJ, Poh EW, Wong PY, Ho SL, Lim WK, Teoh SC. Trends in patterns of anterior uveitis in a tertiary institution in Singapore. Ocul Immunol Inflamm. 2013:21:270-5

390. Wang TJ, Hu CC, Lin HC. Increased risk of anterior uveitis following herpes zoster: a nationwide population-based study. Arch Ophthalmol. 2012; 130:451-5.

391. Sims JL, Yeoh J, Stawell RJ. Acute retinal necrosis: A case series with clinical features and treatment outcomes. Clin Exp Ophthalmol. 2009;37:473-7.

392. Roy R, Pal BP, Mathur G, Rao C, Das D, Biswas J. Acute retinal necrosis: clinical features, management and outcomes-a 10 year consecutive case series. Ocul Immunol Inflamm. 2014;22:170-4.

393. Sodeyama H, Todokoro D, Yamada N, Kishi S. Identification of causative virus and clinical course of acute retinal necrosis. Jpn J Clin Ophthalmol. 2014;68:947-52.

394. Itoh N, Matsumura N, Ogi A, Nishide T, Imai Y, Kanai H, et al. High prevalence of herpes simplex virus type 2 in acute retinal necrosis syndrome associated with herpes simplex virus in Japan. Am J Ophthalmol. 2000;129:404-5.

395. Grover R, Ratho RK, Gupta V, Mahajan RC, Gupta A. Role of viral serology in the diagnosis of acute retinal necrosis syndrome. Ind J Pathol Microbiol. 2002;45:269-71.

396. Madhavan HN. Laboratory investigations on viral and Chlamydia trachomatis infections of the eye: Sankara Nethralaya experiences. Indian J Ophthalmol. 1999;47:241-6.

397. Mizuuchi K, Namba K, Kotake S, Ohno S. Clinical features of acute retinal necrosis at Hokkaido University Hospital. Nihon Ganka Gakkai Zasshi. 2008;112:136-40.

398. Shimakawa M, Sato N. A case of AIDS complicated by progressive outer retinal necrosis. Nihon Ganka Gakkai Zasshi. 1999;103:137-43.

399. Sittivarakul W, Aui-aree N. Clinical features, management and outcomes of progressive outer retinal necrosis (PORN) in southern Thailand. J Med Assoc Thai. 2009;92:360-6.

400. Oshitari K, Arimoto H, Suzuki S, Oguchi Y. Rapidly progressive outer retinal necrosis in a patient with acquired immunodeficiency syndrome. Nihon Ganka Gakkai Zasshi. 1994;98:1141-6.
401. Gill H, Cheung J, Wong I, Lie AK, Kwong YL. Varicella zoster virus progressive outer retinal necrosis after allogeneic haematopoietic stem cell transplantation. Br J Haematol. 2012;157:279

402. Kim SJ, Park SJ, Yu HG, Kim NJ, Jang HC, Oh MD. Ocular manifestations of acquired immunodeficiency syndrome in Korea. J Korean Med Sci. 2012;27:542-6.

403. Lim WK, Chee SP, Nussenblatt RB. Progression of varicella-zoster virus necrotizing retinopathy in an HIV-negative patient with transient immune deviation. Graefes Arch Clin Exp Ophthalmol. 2005;243:607-9.

404. Tseng CC, Chen SN, Hwang JF, Lin CJ, Chen HS. Progressive outer retinal necrosis associated with occlusive vasculitis in acquired immunodeficiency syndrome. J Formos Med Assoc. 2015;114:469-72.

405. Inoue $Y$, Takano M, Kawai H, Ichibe $Y$, Shimizu K. Progressive outer retinal necrosis in a patient with interstitial nephritis. Jpn J Clin Ophthalmol. 2006;60:1087-90.

406. Miyaoka Y, Suzuki J, Yamauchi Y, Goto H. A bilateral case of progressive outer retinal necrosis with retinal detachment resistant to antiviral treatments. Jpn J Clin Ophthalmol. 2008;62:489-92.

407. Ozaki $H$, Jane $H$, Inoue $H$, Kozawa M, Kondo $H$, Uchio E. Outcome of treatment for acute retinal necrosis. Jpn J Clin Ophthalmol. 2011;65:1819-25.

408. Hong J. Discuss on the diagnosis and treatment of viral cornea endotheliitis. Ophthalmol China. 2010;19:158-60.

409. Wang AG, Liu JH, Hsu WM, Lee AF, Yen MY. Optic neuritis in herpes zoster ophthalmicus. Jpn J Ophthalmol. 2000;44:550-4.

410. Menon V, Kumar G, Tandon R. Optic neuropathy secondary to herpes zoster ophthalmicus. Indian J Ophthalmol. 1995;43:78-9.

411. Suraiya MS, Norazlina B, Carmen C, Muhaya M. Bilateral optic neuritis in pregnancy. Med J Malaysia. 2003;58:771-3.

412. Obata H, Yamagami S, Saito S, Sakai O, Tsuru T. A case of acute dacryoadenitis associated with herpes zoster ophthalmicus. Jpn J Ophthalmol. 2003;47:107-9.

413. Yokoyama C, Mori S, Kamada A, Kase S, Ishida S. A case of herpes zoster ophthalmicus with acute dacryoadenitis as the initial manifestation. Jpn J Clin Ophthalmol. 2011;65:945-8.

414. Yong VK, Yip CC, Yong VS. Herpes zoster ophthalmicus and the superior orbital fissure syndrome. Singapore Med J. 2001;42:485-6.

415. Bourke RD, Pyle J. Herpes zoster ophthalmicus and the orbital apex syndrome. Aust New Zealand J Ophthalmol. 1994;22:77-80.

416. Saxena R, Phuljhele S, Aalok L, Sinha A, Menon V, Sharma P, et al. A rare case of orbital apex syndrome with herpes zoster ophthalmicus in a human immunodeficiency virus-positive patient. Indian J Ophthalmol. 2010;58:527-30.

417. Biswas J, Deka S, Padmaja S, Madhavan HN, Kumarasamy N, Solomon S. Central retinal vein occlusion due to herpes zoster as the initial presenting sign in a patient with acquired immunodeficiency syndrome (AIDS). Ocul Immunol Inflamm. 2001;9:125-30.

418. Min SU, Li K, Won CH, Cho S, Huh CH, Kim BJ, et al. Clinical analysis of Ramsay Hunt syndrome. Korean J Dermatol. 2007;45:1121-6.

419. Gondivkar S, Parikh V, Parikh R. Herpes zoster oticus: A rare clinical entity. Contemp Clin Dent. 2010;1:127-9.

420. Murakami S, Hato N, Horiuchi J, Miyamoto Y, Aono H, Honda N, et al. Clinical features and prognosis of facial palsy and hearing loss in patients with Ramsay Hunt syndrome. J Otolaryngol Jpn. 1996;99:1772-9.

421. Ou CY, Chao WY. Herpes zoster oticus. J Otolaryngol Soc Repub China. 1997;32:379-85.

422. Hung CW, Wang SJ, Chen SP, Lirng JF, Fuh JL. Trigeminal herpes zoster and Ramsay Hunt syndrome with a lesion in the spinal trigeminal nucleus and tract. J Neurol. 2010;257:1045-46.

423. McCullough MJ, Savage NW. Oral viral infections and the therapeutic use of antiviral agents in dentistry. Aust Dent J. 2005;50 Suppl 2:S31-5.

424. Sengoku R, Yaguchi H, Matsushima S, Mochio S. Zoster sine herpete: detection by skin exudates and contrast magnetic resonance imaging. Eur Neurol. 2012;67:154

425. Lu YC, Young YH. Vertigo from herpes zoster oticus: superior or inferior vestibular nerve origin? Laryngoscope. 2003;113:307-11.

426. Isawa M. Unilateral deafness and vestibular dysfunction caused by herpes zoster virus. Otolaryngol Head Neck Surg Tokyo. 2001;73:938-41.

427. Shim HJ, Jung H, Park DC, Lee JH, Yeo SG. Ramsay Hunt syndrome with multicranial nerve involvement. Acta Oto-Laryngol. 2011;131:210-5.

428. Lee HH, Huang LK, Hu CJ, Chen CC. Atypical Ramsay Hunt syndrome. Acta Neurol Taiwan. 2014;23:80-1.

429. Miyazaki Y, Tajima Y, Sudo K, Matsumoto A, Kikuchi S, Tashiro K. A case of Ramsay Hunt syndrome initiated with hoarseness and dysphagia: Consideration on spreading mechanisms of cranial neuropathy. Clin Neurol. 2002;42:855-8. 
430. Choi HN, Kim JE, Chung DY, Park SY, Oh JH. Herpes zoster oticus with cranial polyneuropathy without involvement of facial nerve. Korean J Audiol. 2011;15:155-8.

431. Sun $W L$, Yan JL, Chen LL. Ramsay Hunt syndrome with unilateral polyneuropathy involving cranial nerves V, VII, VIII, and XII in a diabetic patient. Quintessence Int. 2011;42:873-7.

432. Sakane S, Enomoto H, Tamaki N, Oridate N. Cases of laryngeal paralysis caused by the varicella-zoster virus (VZV). Pract Oto-Rhino-Laryngol. 2014;107:399-404

433. Kato T. Vocal cord paralysis caused by varicella zoster virus. Otolaryngol Head Neck Surg Tokyo. 2005;77:389-91.

434. Wu CL, Linne OC, Chiang CW. Herpes zoster laryngis with prelaryngeal skin erythema. Ann Otol Rhinol Laryngol. 2004;113:113-4.

435. Morinaka S. Herpes zoster laryngitis with intractable hiccups. Auris Nasus Larynx. 2009;36:606-8.

436. Tamakawa S, Takada M. A case of herpes zoster affecting the glossopharyngeal nerve. J Anesth. 1999;13:230-2.

437. Ling B, Novakovic D, Sulica L. Cough after laryngeal herpes zoster: a new aspect of post-herpetic sensory disturbance. J Laryngol Otol. 2014;128:209-11.

438. Yoshida T, Fujisaki N, Nakachi R, Sueyoshi T, Suwazono S, Suehara M. Persistent hiccups and vomiting with multiple cranial nerve palsy in a case of zoster sine herpete. Intern Med. 2014;53:2373-6.

439. Shim JH, Park JW, Kwon BS, Ryu KH, Lee HJ, Lim WH, et al. Dysphagia in Ramsay Hunt's Syndrome - A Case Report -. Ann Rehabil Med. 2011;35:738-41.

440. Ono N, Sakabe A, Nakajima M. Herpes zoster oticus-associated jugular foramen syndrome. Brain Nerve. 2010;62:81-4.

441. Fang CW, Lin CC. Ramsay Hunt syndrome with hemiparesis and hemihypoesthesia: report of 2 cases. Acta Neurol Taiwan. 2009;18:276-80.

442. Furuta Y, Ohtani F, Kawabata H, Fukuda S, Bergström T. High prevalence of varicella-zoster virus reactivation in herpes simplex virus seronegative patients with acute peripheral facial palsy. Clin Infect Dis 2000;30:529-33.

443. Kawaguchi K, Inamura H, Abe Y, Koshu H, Takashita E, Muraki Y, et al. Reactivation of herpes simplex virus type 1 and varicella-zoster virus and therapeutic effects of combination therapy with prednisolone and valacyclovir in patients with Bell's palsy. Laryngoscope. 2007;117:147-56.

444. Terada K, Niizuma T, Kawano S, Kataoka N, Akisada T, Orita Y. Detection of varicella-zoster virus DNA in peripheral mononuclear cells from patients with Ramsay Hunt syndrome or zoster sine herpete. J Med Virol. 1998;56:359-63.

445. Takahash $\mathrm{K}$, Aono $T$, Shichinohe M, Tamura M, Iwata Y, Yamanishi K, et al. Herpesvirus DNA in peripheral blood mononuclear cells of some patients with Meniere's disease. Microbiol Immunol. 2001;45:635-8.

446. Yazawa Y, Suzuki M, Hanamitsu M, Kimura H, Tooyama I. Detection of viral DNA in the endolymphatic sac in Ménière's disease by in situ hybridization. ORL J Otorhinolaryngol Relat Spec. 2003;65:162-8.

447. Hoshino C, Yamabe A. Where is reactivation after a long latency? BMJ Case Rep. 2012; doi:10.1136/bcr.01.2012.5538.

448. Son HH, Sim HS, Lee SK. Clinical study of motor paresis in in-patients with herpes zoster. Korean J Dermatol. 2011;49:961-8.

449. Gopal KVT, Sarvani D, Krishnam Raju PV, Rao GR, Venkateswarlu K. Herpes zoster motor neuropathy: A clinical and electrophysiological study. Indian J Dermatol Venereol Leprol. 2010;76:569-71.

450. Takahashi T, Tamura M, Miki K, Yamaguchi M, Kanno A, Nunomura S, et al. Varicella zoster virus myelitis in two elderly patients: diagnostic value of nested polymerase chain reaction assay and antibody index for cerebrospinal fluid specimens. Case Rep Neurol. 2013;5:81-90.

451. Liu W, Zhu YY, Jiang FX, He J, Hu B. A case of systemic lupus erythematosus with herpes zoster myelitis. J Clin Dermatol. 2013;42:412-3.

452. Ong OL, Churchyard AC, New PW. The importance of early diagnosis of herpes zoster myelitis. Med J Aust. 2010;193:546-7.

453. Mehndiratta MM, Bansal J, Gupta M, Puri V. Herpes zoster cervical myelitis in an immunocompetent subject. Neurol India. 2000;48:189-90.

454. Akiyama N. Herpes zoster infection complicated by motor paralysis. J Dermatol. 2000;27:252-7.

455. Tak WJ, Chong YS, Seo SJ, Hong CK. A case of motor paralysis caused by herpes zoster. Korean J Dermatol. 2002;40:1157-60.

456. Shin SJ, Yoo CS, Kil MS, Kim CW, Kim SS. A case of motor paralysis of the limb caused by herpes zoster. Korean J Dermatol. 2012;50:621-3.

457. Fujimoto S, Matsuno O, Matsumoto T, Kumamoto T, Tsuda T. A case of diaphragmatic paralysis following herpes zoster. Clin Neurol. 1996;36: 345-7.
458. Her Y, Kim CW, Kim SS. A clinical study of motor involvement by herpes zoster. Korean J Dermatol. 2010;48:468-73.

459. Lee CC, Wu JC, Huang WC, Shih YH, Cheng H. Herpes zoster cervical myelitis in a young adult. J Chin Med Assoc. 2010;73:605-10.

460. Hosaka A, Nakamagoe K, Watanabe M, Tamaoka A. Magnetic resonance images of herpes zoster myelitis presenting with Brown-Séquard syndrome. Arch Neurol. 2010;67:506.

461. Lee MH, Song JH, Lee DI, Ahn HS, Park JW, Cha YD. Newly developed urinary retention and motor weakness of lower extremities in a postherpetic neuralgia patient. Korean J Pain. 2013;26:76-9.

462. Tseng YH. Acute orbital myositis heralding herpes zoster ophthalmicus: report of a case. Acta Neurol Taiwan. 2008;17:47-9.

463. Kang JH, Sheu JJ, Lin HC. Increased risk of Guillain-Barré Syndrome following recent herpes zoster: a population-based study across Taiwan. Clin Infect Dis. 2010;51:525-30.

464. Wakasugi K, Imaizumi T, Nishimura Y, Fujimoto H, Ayabe M, Shoji H, et al. Guillain-Barré syndrome associated with herpes zoster. Intern Med. 2001;40:552.

465. Nagane $Y$, Utsugisawa K, Obara D. A case of herpes zoster associated Guillain-Barré syndrome with a relapse of eruptions after intravenous immunoglobulin therapy. Clin Neurol. 2006;46:664-7.

466. Sheu JJ, Keller JJ, Lin HC. Increased risk of cancer after Bell's palsy: a 5-year follow-up study. J Neurooncol. 2012;110:215-20.

467. Sanjay S, Chan EW, Gopal L, Hegde SR, Chang BC. Complete unilatera ophthalmoplegia in herpes zoster ophthalmicus. J Neuroophthalmol. 2009;29:325-37.

468. Shin HM, Lew H, Yun YS. A case of complete ophthalmoplegia in herpes zoster ophthalmicus. Korean J Ophthalmol. 2005;19:302-4.

469. Sato R, Yamada M, Tamai K. Total ophthalmoplegia in a case of herpes zoster ophthalmicus. Jpn J Clin Ophthalmol. 2008;62:1279-83.

470. Im M, Kim BJ, Seo YJ, Park JK, Lee JH. Complete ophthalmoplegia after herpes zoster. Clin Exp Dermatol. 2007;32:162-4.

471. Nakazawa T, Omura M, Sugita R. A case of herpes zoster ophthalmicus with total ophthalmoplegia. Jpn J Clin Ophthalmol. 1998;52:1933-7.

472. Ying XH, Wagle AM, Tan L, Sanjay S, Hedge SR, Chew YC, et al. A rare case of herpes zoster ophthalmicus with complete ophthalmoplegia. J Am Geriatr Soc. 2008;56:2160-2.

473. Jang SJ, Choe YB, Ahn KJ. A Case of motor paralysis caused by herpes zoster. Korean J Dermatol. 2004;42:236-8.

474. Tam TC, Chan KY, Ho SL, Luk JK, Chu LW. Herpetic shoulder paresis in a Chinese elderly patient. Hong Kong Med J. 2005;11:399-402.

475. Kang SH, Song HK, Jang Y. Zoster-associated segmental paresis in a patient with cervical spinal stenosis. J Int Med Res. 2013;41:907-13.

476. Siddalingappa K, Lokanatha K. Segmental motor paralysis of the right upper limb in herpes zoster. Indian J Dermatol Venereol Leprol. 2006; 72:252.

477. Wu CM, Hsu CY, Shie HH. Herpes zoster motor neuropathy in an elderly man. Eur Geriatr Med. 2014;5:216-7.

478. Kawajiri S, Tani M, Noda K, Fujishima K, Hattori N, Okuma Y. Segmental zoster paresis of limbs: report of three cases and review of literature. Neurologist. 2007;13:313-7.

479. Namekawa M, Kameda T, Kumabe A, Mise J. Segmental zoster paresis of the right shoulder. Intern Med. 2013;52:2839.

480. Fabian VA, Wood B, Crowley P, Kakulas BA. Herpes zoster brachial plexus neuritis. Clin Neuropathol. 1997;16:61-4.

481. Choi JY, Kang CH, Kim BJ, Park KW, Yu SW. Brachial plexopathy following herpes zoster infection: two cases with MRI findings. J Neurol Sci. 2009;285:224-6.

482. Bessho M, Nakajima H, Ito T, Kitaoka H. A case of incomplete Brown-Séquard syndrome after thoracic herpes zoster infection. Clin Neurol. 2010;50:175-89.

483. Seo DH, Lee SJ, Hyun JK, Kim TU. A case of herpes zoster peripheral polyneuropathy manifested by foot drop in chronic myeloid leukemia. Ann Rehabil Med. 2012;36:724-8.

484. Kim JB, Jung HJ, Lee JM, Im KS, Joo CH, Kim JW. Disseminated herpes zoster with a zoster paresis-induced femoral fracture. Geriatr Gerontol Int. 2012;12:168-71.

485. Kim SY, Hwang KE, Jung JH, Park JH, Kim HJ, Kim HR, et al. Diaphragmatic paralysis following cervical herpes zoster. Tuberc Respir Dis. 2006;61:80-2.

486. Koh YM, Baik JJ, Woo SI, Park KW, Chung Y. Diaphragmatic paralysis induced by herpes zoster. Tuberc Respir Dis. 1996;43:92-5. 
487. Lin CM, Shieh WB, Chiang PC, Shieh MG, Liu YC, Chiou CC, et al. An unusual cause of dyspnea in a patient with cervical herpes zoster. J Clin Neurosci. 2012;19:608-9.

488. Zhou SR, Liu CY. A case report of abdominal distention caused by herpes zoster. World J Gastroenterol. 2012;18:4627-8.

489. Lee UH, Park HS, Choi JC, Chun DK. A case of abdominal protrusion caused by herpes zoster. Korean J Dermatol. 2004;42:659-61.

490. Chang TCC, Chin YY, Lan CCE. Herpes zoster with autonomic dysregulation presented as alteration in local microcirculation: A case report. Dermatol Sin. 2011;29:72-4.

491. Sharma PK, Gautam RK, Basistha C, Jain RK, Kar HK. Abdominal hernia following abdominal herpes zoster. Indian J Dermatol Venereol Leprol. 2001:67:39-40

492. Tashiro S, Akaboshi K, Kobayashi Y, Mori T, Nagata M, Liu M. Herpes zosterinduced trunk muscle paresis presenting with abdominal wall pseudohernia, scoliosis, and gait disturbance and its rehabilitation: a case report. Arch Phys Med Rehabil. 2010;91:321-5.

493. Kim ED, Kang BG, Kim JH, Roh M, Jo DH. Abdominal distention and constipation followed by herpes zoster infection. Korean J Anesthesiol. 2013;65 Suppl 6:S143-4.

494. Maeda K, Furukawa K, Sanada M, Kawai H, Yasuda H. Constipation and segmental abdominal paresis followed by herpes zoster. Intern Med. 2007:46:148-8.

495. Kim JH, Lee SH, Na GJ, Lee SJ, Jo YG, Lee TH, et al. A rare case of Ogilvie syndrome associated with herpes zoster. Intest Res. 2012;10:379-82.

496. Hiramatsu S, Nebiki H, Ueno A, Wakahara Y, Maruyama H, Suekane T, et al. A case of paralytic ileus associated with varicella zoster virus infection. Nihon Shokakibyo Gakkai Zasshi. 2013;110:1007-13.

497. Imafuku S, Takahara M, Uenotsuchi T, Iwato K, Furue M. Herpes zosterassociated voiding dysfunction in hematopoietic malignancy patients. Int J Dermatol. 2008;47:36-9.

498. Chen PH, Hsueh HF, Hong CZ. Herpes zoster-associated voiding dysfunction: a retrospective study and literature review. Arch Phys Med Rehabil. 2002;83:1624-8.

499. Tsai HN, Wu WJ, Huang SP, Su CM, Chen CC, Wang CJ, et al. Herpes zoster induced neuropathic bladder-a case report. Kaohsiung J Med Sci. 2002;18:39-44.

500. Hiraga A, Nagumo K, Sakakibara R, Kojima S, Fujinawa N, Hashimoto T. Loss of urinary voiding sensation due to herpes zoster. Neurourol Urodyn. 2003; 22:335-7.

501. Matsuo T, Oba K, Miyata Y, Igawa T, Sakai H. Four cases of urinary dysfunction associated with sacral herpes zoster. Acta Urol Jpn. 2014;60:87-90.

502. Addison B, Harvey M. Herpes zoster-induced acute urinary retention. Emerg Med Australas. 2013;25:279-81.

503. Yamanishi T, Yasuda K, Sakakibara R, Hattori T, Uchiyama T, Minamide M, et al. Urinary retention due to herpes virus infections. Neurourol Urodyn. 1998; 17:613-9.

504. Fukao M, Isogai R, Kawada A, Shimizu N, Matsumoto S. Herpes zoster associated with bladder/rectum symptom. Skin Res. 2005;4:386-9

505. Matsumoto H, Shimizu T, Tokushige S, Mizuno H, Igeta Y, Hashida H. Recta ulcer in a patient with VZV sacral meningoradiculitis (Elsberg syndrome). Intern Med. 2012;51:651-4.

506. Chen JH, Chen KY. Acute sciatica in a patient with herpes zoster infection. Acta Clin Belg. 2011:66:70-1.

507. Kang JH, Ho JD, Chen YH, Lin HC. Increased risk of stroke after a herpes zoster attack: a population-based follow-up study. Stroke. 2009;40:3443-8.

508. Lin HC, Chien CW, Ho JD. Herpes zoster ophthalmicus and the risk of stroke: a population-based follow-up study. Neurology. 2010;74:792-7.

509. Chen WH, Chui C, Yin HL. Zoster sine herpete, vertebral artery stenosis, and ischemic stroke. J Stroke Cerebrovasc Dis. 2013;22:e234-7.

510. Verma R, Lalla R, Patil TB. Extensive extracranial and intracranial Varicella zoster vasculopathy. BMJ Case Rep. 2012; doi:10.1136/bcr-2012-006845

511. Hoshino S, Hayashi A, Yoshizawa T, Tamaoka A, Shoji S. A case of delayed cerebral infarction occurring in puerperium preceded by herpes zoster ophthalmicus in late pregnancy. No To Shinkei. 1999:51:529-33.

512. Kim MJ, Lee KO, Lee KY, Oh SH, Na SJ, Yoon B, et al. Hemichorea caused by intracranial hemorrhage following contralateral herpes zoster ophthalmicus. J Clin Neurosci. 2013;20:738-9.

513. Song HJ, Hong WK, Lee HS, Choi GS, Shin JH. Herpes zoster complicated by delayed intracranial haemorrhage. Clin Exp Dermatol. 2009;34:518-9.

514. Verma $R$, Singh $D$, Sharma $P$. Contralateral stroke with rapid recovery in a patient of herpes zoster ophthalmicus. Neurol Asia. 2011;16:247-50.
515. Kalita J, Das M, Misra UK. Herpes zoster ophthalmicus leading to middle cerebral artery infarction: A case report. Int J Angiol. 2004;13:51-3.

516. Fukutake T, Hatakeyama $H$, Shinotoh H, Hattori T. Herpes zoster ophthalmicus and delayed contralateral hemiparesis: a case of ipsilateral midbrain involvement. Eur Neurol. 1998;40:57-8.

517. Lee SJ, Lee DG. Isolated gait ataxia as a sole manifestation of right lateral medullary infarct following ipsilateral trigeminal herpes zoster. Case Rep Neurol. 2014;6:193-6.

518. Yasuda C, Okada K, Ohnari N, Akamatsu N, Tsuji S. Cerebral infarction and intracranial aneurysm related to the reactivation of varicella zoster virus in a Japanese acquired immunodeficiency syndrome (AIDS) patient. Clin Neurol. 2013;53:701-5.

519. Bhat G, Mathur DS, Saxena GN, Jain S, Singh AP, Bhaduria D. Granulomatous angiitis of the central nervous system associated with herpes zoster. J Assoc Physicians India. 2002;50:977-8.

520. Vibha D, Prabhakar S, Khurana D, Khandelwal N. Varicella zoster vasculopathy presenting as lateral medullary syndrome. J Neurovirol. 2012;18:538-40.

521. Nagafuchi M, Nagafuchi $Y$, Sato R, Imaizumi T, Ayabe M, Shoji $H$, et al. Adult meningism and viral meningitis, 1997-2004: Clinical data and cerebrospinal fluid cytokines. Intern Med. 2006;45:1209-12.

522. Fujita H, Kurokawa S, Imaizumi S, Kawasaki H, Harada K. Two cases of meningitis developed while undergoing therapy for herpes zoster. Nishinihon J Dermatol. 1994:56:992-5.

523. Takeshima S, Neshige S, Himeno T, Hara N, Yoshimoto T, Takamatsu K, et al. Clinical, epidemiological, and etiological studies of aseptic meningitis in adults. Clin Neurol. 2014:54:791-7.

524. Choi R, Kim GM, Jo IJ, Sim MS, Song KJ, Kim BJ, et al. Incidence and clinical features of herpes simplex viruses (1 and 2) and varicella-zoster virus infections in an adult Korean population with aseptic meningitis or encephalitis. J Med Virol. 2014;86:957-62.

525. Srivastava T, Nagpal K. Herpes zoster meningoencephalitis complicated with peripheral vascular disease: an uncommon presentation of a common disease. Scand J Infect Dis. 2014;46:716-8.

526. Ohtomo R, Shirota Y, Iwata A, Shimizu J, Tsuji S. Cerebral microbleeding in varicella-zoster viral meningitis: an early sign of vasculopathy? Neurology. 2014;82:814-5.

527. Park HK, Lee JH. A case of ramsay hunt syndrome complicated by cerebellitis. J Clin Neurol. 2006;2:198-201.

528. Saxena A, Khiangte B, Tiewsoh I, Jajoo UN. Herpes zoster encephalitis presenting as multiple cerebral hemorrhages - a rare presentation: a case report. J Med Case Rep. 2013;7:155.

529. Baek W, Lee SG, Kim YS, Kim JH, Jun JB, Kim HY. Fatal varicella-Zoster virus vasculopathy associated with adalimumab therapy. Arch Neurol. 2012;69:1193-6.

530. Sasson SC, Oon A, Chagantri J, Brew BJ, Carr A. Posterior reversible encephalopathy syndrome (PRES) in an HIV-1 infected patient with disseminated varicella zoster virus: a case report. BMC Infect Dis 2013;13:396.

531. Wang L, Holthaus EA, Jimenez XF, Tavee J, Li Y. MRI evolution of CLIPPERS syndrome following herpes zoster infection. J Neurol Sci. 2015:348:277-8.

532. McKelvie PA, Collins S, Thyagarajan D, Trost N, Sheorey H, Byrne E. Meningoencephalomyelitis with vasculitis due to varicella zoster virus: a case report and review of the literature. Pathology. 2002;34:88-93.

533. Douglas A, Harris P, Francis F, Norton R. Herpes zoster meningoencephalitis: Not only a disease of the immunocompromised? Infection. 2010;38:73-5.

534. Sugisaki K, Yoshida H. Varicella zoster virus meningoencephalitis accompanied by sporadic skin lesions in an older immunocompetent adult. J Infect Chemother. 2007;13:270-2.

535. Chun WC, Kin MT, Wing KT, Tin CL, Wai KK. Hypoglycorrhachia in herpes zoster associated encephalitis of an immunocompetent young male: An unusual presentation. J Neurol. 2005:252:987-8.

536. Miyazaki Y, Riku Y, Goto Y, Mano K, Yoshida M, Hashizume Y. VZV vasculopathy associated with myelo-radiculoganglio-meningo-encephalitis: an autopsy case of an immunocompetent 66-year-old male. J Neurol Sci. 2008;275:42-5.

537. Byun JW, Song HJ, Choi GS, Shin JH. A clinical study on herpes zoster meningoencephalitis. Korean J Dermatol. 2011;49:328-33.

538. Yoshifuku A, Ueki Y, Tamai M, Miyoshi H, Higashi Y, Kanekura T, et al. A case of herpes zoster associated with meningoencephalitis. Nishinihon J Dermatol. 2009;71:494-6.

539. Pandey PK, Garg D, Bhatia A, Jain V. Horner's syndrome and sixth nerve palsy due to herpes zoster ophthalmicus arteritis. Eye. 2005;19:224-6. 
540. Kobayashi Y, Yamamoto T. A case of Horner's syndrome associated with ophthalmic herpes zoster. Clin Neurol. 2007:47:105-8.

541. Tsuda H, Tanaka K. Internal carotid artery involvement in herpes zoster ophthalmicus. Intern Med. 2012;51:2067-8,

542. Nishitani M, Kodama T, Ohashi Y, Tatematsu Y, Maruo H. A case of cavernous sinus syndrome following herpes zoster ophthalmicus. Folia Ophthalmol Jpn. 2002;53:898-903.

543. Cho BJ, Kim JS, Hwang JM. Horner's syndrome and contralateral abducens nerve palsy associated with zoster meningitis. Korean J Ophthalmol. 2013;27:474-7.

544. Camuglia JE, Beltz JE, Khurana K, Hall AJ. An unusual cause of visual loss after Herpes zoster ophthalmicus: a case report. Cases J. 2010;3:17.

545. Roberts TV, Francis IC, Kappagoda MB, Dick AD. Herpes zoster chorioretinopathy. Eye (Lond). 1995;9:594-8.

546. Wang CC, Lin CL, Chang YJ, Wang GJ, Sung FC, Kao CH. Herpes zoster infection associated with acute coronary syndrome: a population-based retrospective cohort study. Br J Dermatol. 2014;170:1122-9.

547. Wu PY, Lin CL, Sung FC, Chou TC, Lee YT. Increased risk of cardiovascular events in patients with herpes zoster: a population-based study. J Med Virol. 2014;86:772-7.

548. Maity PK, Chakrabarti N, Mondal M, Patar K, Mukhopadhyay M. Deep vein thrombosis: A rare signature of herpes zoster. J Assoc Physicians India. 2014;62:72-4.

549. Kundu AK. Herpes zoster-induced myocarditis in a patient with diabetes mellitus. J Assoc Physicians India. 1999;47:286-7.

550. Cheung MY, Viney M. A unique case of recurrent asystole secondary to paroxysmal pain of acute herpetic ophthalmicus. Anesth Analg. 2007;105: $1127-9$.

551. Kume T, Hirose M, Yamashita T, Mizuno S, Hosokawa T, Sekimoto M, et al. Analysis of blood pressure in elderly patients with postherpetic neuralgia. Pain Clinic. 2001;13:153-7.

552. Lee HW, Kim KJ, Chang SE, Lee MW, Choi JH, Moon KC, et al. A case of generalized herpes zoster associated with herpetic folliculitis and syringitis. Korean J Dermatol. 2005;43:274-6.

553. Park JS, Ryu H, Ha SH, Park HS, Lee J, Son SJ. Two cases of herpetic syringitis. Korean J Dermatol. 2002;40:1449-51.

554. Tanaka A, Hayaishi N, Kondo Y, Kurachi K, Tanemura A, Katayama I. Severe gangrene accompanied by varicella zoster virus-related vasculitis mimicking rheumatoid vasculitis. Case Rep Dermatol. 2014;6:103-7.

555. Khong JJ, Casson RJ, Huilgol SC, Selva D. Madarosis. Surv Ophthalmol. 2006; 51:550-60.

556. Baek JH, Hong KC, Lee DY, Kim MS, Lee UH, Park HS. Alopecia areata associated with Herpes zoster. J Dermatol. 2013;40:672.

557. Garg P, Mathur U, Athmanathan S, Rao GN. Treatment outcome of Moraxella keratitis: our experience with 18 cases-a retrospective review. Cornea. 1999;18:176-81.

558. Yang SC, Ho HC, Lay CJ, Tsai CC. Aspergillus invasive otitis externa as a complication of herpes zoster oticus. Tzu Chi Med J. 2011;23:28-30.

559. Seo JK, Lee SM, Lee SK. Clinical observation of bacterial studies in the skin lesions of patients with herpes zoster. Korean J Dermatol. 2007:45:1031-40.

560. Yamada Y, Ito R, Bito M, Tashima S, Sakamoto K, Konishi K. A case of subcutaneous abscess at the site of herpes zoster in a patient with poorly controlled diabetes. Skin Res. 2014;13:13-5.

561. Jarrett P, Ha T, Oliver F. Necrotizing fasciitis complicating disseminated cutaneous herpes zoster. Clin Exp Dermatol. 1998;23:87-8.

562. Ong CW, Ang BS, Lee CC. Severe varicella infection occurring after herpes zoster reactivation in a patient with AIDS. BMJ Case Rep. 2009; doi:10.1136/ bcr.09.2008.0952

563. Gupta S, Gupta S, Thomas M, Mahendra A, Jindal N, Bhaskar G, et al. Herpes Zoster with disseminated lesions. What is it? J Med Life. 2013;6:84-5.

564. Garg G, Thami GP. Psoriasis herpeticum due to varicella zoster virus: A Kaposi's varicelliform eruption in erythrodermic psoriasis. Indian J Dermatol. 2012;57:213-4

565. Gupta S. Many faces of Koebner phenomenon in psoriasis. Indian J Dermatol Venereol Leprol. 2002;68:222-4.

566. Terao M, Tanemura A, Katayama I. Vitiligo exacerbated after herpes zoster. J Dermatol. 2012;39:938-9.

567. Huang CW, Tu ME, Wu YH, Lin YC. Isotopic response of fungal granuloma following facial herpes zoster infections - report of three cases. Int J Dermatol. 2007:46:1141-5.

568. Ghorpade A. Wolf's isotopic response - Furuncles at the site of healed herpes zoster in an Indian male. Int J Dermatol. 2010;49:105-7.
569. Kim SM, Lee SY, Rhee CH, Lee JS, Yun SK, Kim HU, et al. A case of papular granuloma annulare occurring on the site of herpes zoster: Isotopic response. Korean J Dermatol. 2008:46:818-20.

570. Ohata C, Shirabe H, Takagi K, Kawatsu T. Granuloma annulare in herpes zoster scars. J Dermatol. 2000;27:166-9.

571. Wang T, Liu YH, Zheng HY, Yu BT, Fang K. A case of nonspecific granulomatous perivasculitis on herpes zoster scars. J Clin Dermatol. 2010;39:163-4.

572. Inaoka M, Kano Y, Horie C, Shiohara T. Cutaneous granulomatous reaction after herpes zoster in drug-induced hypersensitivity syndrome. Am J Dermatopathol. 2011;33:872-4.

573. Suh KS, Choi SY, Jeon YS, Sim HJ, Kim ST. A case of granuloma annulare occurring on herpes zoster. Korean J Dermatol. 2005;43:834-6.

574. Chang SE, Bae GY, Moon KC, Do SH, Lim YJ. Subcutaneous granuloma annulare following herpes zoster. Int J Dermatol. 2004;43:298-9.

575. Ohmori S, Sugita K, Ikenouchi-Sugita A, Nakamura M. Erythema annulare centrifugum associated with herpes zoster. J UOEH. 2012;34:225-9.

576. Sugita K, Kabashima K, Tokura Y. Erythema annulare centrifugum associated with herpes zoster. Eur J Dermatol. 2008;18:205-6.

577. Lee HW, Lee DK, Rhee DY, Chang SE, Choi JH, Moon KC, et al. Erythema annulare centrifugum following herpes zoster infection: Wolf's isotopic response? Br J Dermatol. 2005;153:1241-3.

578. Onishi I, Kishimoto S. Erythema multiforme after resolution of herpes zoster by acyclovir. Eur J Dermatol. 2002;12:370-2.

579. Kim JS, Kim MH, Choi HY, Myung KB. A Case of zosteriform lichen planus occurring on herpes zoster lesions. Korean J Dermatol. 2004;42:217-9.

580. Choi HJ, Chang SE, Lee MW, Choi JH, Moon KC, Koh JK. A case of zosteriform lichen planus on the site of healed herpes zoster: Wolf's isotopic response. Korean J Dermatol. 2004;42:456-9.

581. Noh TW, Park SH, Kang YS, Lee UH, Park HS, Jang SJ. Morphea developing at the site of healed herpes zoster. Ann Dermatol. 2011;23:242-5.

582. Qu T, Fang K. Bullous morphea arising at the site of a healed herpes zoster. J Dermatol. 2014:41:553-4.

583. Endo Y, Tanioka M, Tanizaki H, Mori M, Kawabata H, Miyachi Y. Bullous variant of Sweet's syndrome after herpes zoster virus infection. Case Rep Dermatol. 2011;3:259-62.

584. Ghorpade AK. Reactive perforating collagenosis with a giant lesion at the site of healed herpes zoster. Indian I Dermatol Venereol Leprol. 2011;77:202-3.

585. Bang SW, Kim YK, Whang KU. Acquired reactive perforating collagenosis: unilateral umbilicated papules along the lesions of herpes zoster. J Am Acad Dermatol. 1997;36:778-9.

586. Lee HJ, Roh KY, Ha SJ, Kim JW. Pitted keratolysis of the palm arising after herpes zoster. Br J Dermatol. 1999;140:974-5.

587. Miura T, Yamamoto T. Post-herpes zoster sarcoidosis. J Dermatol. 2014;41:458-9.

588. Watanabe D, Kuhara T, Ishida N, Tamada Y, Matsumoto Y. Sarcoid tissue reaction on herpes zoster scars in a myelodysplastic syndrome patient: Wolf's isotopic response. J Eur Acad Dermatol Venereol. 2009;23:475-7.

589. Verma KK, Mittal R. Cutaneous lesions of multicentric reticulohystiocytosis developing in herpes zoster lesions. Acta Derm Venereol. 2000;80:150.

590. Yamamoto T, Yokoyama A. Nodular solar degeneration following herpes zoster. Br J Dermatol. 1996;134:606.

591. Mittal RR, Singh SP, Gupta S, Sethi PS. Nodular colloid degeneration over herpes zoster scars. Indian J Dermatol Venereol Leprol. 1996;62:181-2.

592. Kwon Jl, Cho JW, Lee KS. A case of verrucous hyperplasia at the site of healed herpes zoster: Isotopic response. Korean J Dermatol. 2011;49:726-9.

593. Kim MB, Jwa SW, Ko HC, Kim SJ, Kwon KS, Oh CH. A case of secondary cutaneous mucinosis following herpes zoster: Wolf's isotopic response. Int J Dermatol. 2009:48:212-4.

594. Lee HJ, Ahn WK, Chae KS, Ha SJ, Kim JW. Localized chronic urticaria at the site of healed herpes zoster. Acta Derm Venereol. 1999;79:168.

595. De D, Dogra S, Kanwar AJ. Prurigo nodularis in healed herpes zoster scar: An isotopic response. J Eur Acad Dermatol Venereol. 2007;21:711-2.

596. Lee YB, Park HJ, Lee JY, Cho BK. Two cases of chronic cutaneous graftversus-host-reaction on the site of healed herpes zoster as an isotopic response. Korean J Dermatol. 2008:46:90-3.

597. Matsumura T, Watanabe $H$, Batchelor J, Sueki H, lijima M. Drug eruption caused by the nonionic contrast medium iohexol. Recall-like phenomenon' appearing on an area previously affected by herpes zoster. J Dermatol. 2006;33:705-8.

598. Na SY, Lee HY, Baek JO, Roh JY, Lee JR. A case of cutaneous zosteriform metastatic carcinoma arising on the healed site of herpes zoster. Korean Dermatol. 2008:46:347-51. 
599. Hapgood G, Mooney E, Dinh HV, Gin D, McLean C, Ting SB. Leukaemia cutis in chronic lymphocytic leukaemia following varicella zoster virus reactivation. Intern Med J. 2012;42:1355-8.

600. Kim TH, Kim DH, Yeom JS, Lee GY, Kim WS, Kim KJ. A case of AIDSassociated Kaposi's sarcoma on the site of healed herpes zoster as an isotopic response. Korean J Dermatol. 2009:47:1172-6.

601. Kim CY, Nam YH, Kim GD, Oh CW. Tufted angioma in site of healed herpes zoster: Isotopic response. Clin Exp Dermatol. 2006;31:714-5.

602. Siwamogstham P, Kuansuwan C, Reichart PA. Herpes zoster in HIV infection with osteonecrosis of the jaw and tooth exfoliation. Oral Dis. 2006;12:500-5.

603. Volvoikar P, Patil S, Dinkar A. Tooth exfoliation, osteonecrosis and neuralgia following herpes zoster of trigeminal nerve. Indian J Dent Res. 2002;13:11-4.

604. Pillai KG, Nayar K, Rawal YB. Spontaneous tooth exfoliation, maxillary osteomyelitis and facial scarring following trigeminal herpes zoster infection. Prim Dent Care. 2006;13:114-6.

605. Jain MK, Manjunath KS, Jagadish SN. Unusual oral complications of herpes zoster infection: report of a case and review of literature. Oral Surg Oral Med Oral Pathol Oral Radiol Endod. 2010;110:e37-41.

606. Lambade P, Lambade D, Saha TK, Dolas RS, Pandilwar PK. Maxillary osteonecrosis and spontaneous teeth exfoliation following herpes zoster. Oral Maxillofac Surg. 2012;16:369-72.

607. Yamamoto K, Inagake K, Tatebayashi S, Yamakawa N, Inoue M, Yasumoto J, et al. Alveolar osteonecrosis of the mandible after varicella zoster infection of the trigeminal nerve. Asian J Oral Maxillofac Surg. 2004;16:204-8.

608. Badjate SJ, Cariappa KM, Shenoi SR, Nakhate S. Ramsay-Hunt syndrome complicating osteonecrosis of edentulous maxilla and mandible: report of a rare case. J Maxillofac Oral Surg. 2009:8:188-91.

609. Pushpanshu K, Kaushik R, Srivastava S, Punyani SR. An unusual complication of tooth exfoliation and osteonecrosis following herpes zoster infection of trigeminal nerve: a case report and literature review. Minerva Stomatol. 2013;62:241-5.

610. Mahima VG, Patil K, Srikanth HS. Herpes zoster induced alveolar necrosis in an immunocompetent patient. Iran J Clin Infect Dis. 2010;5:235-8.

611. Liu YC, Yang YH, Hsiao HH, Yang WC, Liu TC, Chang CS, et al. Herpes zoster is associated with an increased risk of subsequent lymphoid malignancies a nationwide population-based matched-control study in Taiwan. BMC Cancer. 2012;12:503.

612. Ho JD, Xirasagar S, Lin HC. Increased risk of a cancer diagnosis after herpes zoster ophthalmicus: a nationwide population-based study. Ophthalmology. 2011;118:1076-81.

613. Yamamoto M, Mine H, Akazawa K, Maehara Y, Sugimachi K. Gastrointestinal cancer and herpes zoster in adults. Hepatogastroenterology. 2003;50:1043-6.

614. Lin SY, Liu JH, Yeh HC, Lin CL, Tsai IJ, Chen PC, et al. Association between herpes zoster and end stage renal disease entrance in chronic kidney disease patients: a population-based cohort study. Eur J Clin Microbio Infect Dis. 2014;33:1809-15.

615. Jiang ZM, Gao YH, Meng W, Wu WY, Jin L, Shen FM. The study on familial aggregation of systemic lupus erythematosus. Fudan Univ J Med Sci. 2005 32:270-4.

616. Kang JH, Sheu JJ, Kao S, Lin HC. Increased risk of multiple sclerosis following herpes zoster: a nationwide, population-based study. J Infect Dis. 2011;204: 188-92.

617. Tsai SY, Yang TY, Chen HJ, Chen CS, Lin WM, Shen WC, et al. Increased risk of chronic fatigue syndrome following herpes zoster: a population-based study. Eur J Clin Microbiol Infect Dis. 2014;33:1653-9.

618. Chen MH, Wei HT, Su TP, Li CT, Lin WC, Chang WH, et al. Risk of depressive disorder among patients with herpes zoster: a nationwide population-based prospective study. Psychosom Med. 2014;76:285-91.

619. Wang X, Zhang L, Lei Y, Liu X, Zhou X, Liu Y, et al. Meta-analysis of infectious agents and depression. Sci Rep. 2014;4:4530.

620. Chen YH, Chen YK, Keller JJ, Lin HC. A population-based case-control analysis of the association between herpes zoster and erectile dysfunction. J Infect. 2012;65:150-6.

621. Chiu HF, Chen BK, Yang CY. Herpes zoster and subsequent risk of cancer: a population-based study. J Epidemiol. 2013;23:205-10.

622. Wang YP, Liu CJ, Hu YW, Chen TJ, Lin YT, Fung CP. Risk of cancer among patients with herpes zoster infection: a population-based study. CMAJ. 2012; 184:E804-9.

623. Wang CC, Shiang JC, Chen JT, Lin SH. Syndrome of inappropriate secretion of antidiuretic hormone associated with localized herpes zoster ophthalmicus. J Gen Intern Med. 2011;26:216-20.
624. O'Rourke F, Chilov M. Localised herpes zoster infection and SIADH. Aust Fam Physician. 2006;35:789-90.

625. Furuta E, Yasuda M, Yoshioka K, Isayama T, Nobunaga M. Syndrome of inappropriate secretion of antidiuretic hormone in elderly patients with rheumatoid arthritis associated with infections: Report of two cases. Intern Med. 1996;35:478-81.

626. Reid AB, Gome JJ. Localized herpes zoster infection causing the syndrome of inappropriate antidiuretic hormone secretion. Intern Med J. 2009;39:486-7.

627. Tsutsumi R, Adachi K, Yoshida Y, Yamamoto O. Drug-induced hypersensitivity syndrome in association with varicella. Acta Derm Venereol. 2015;95:503-4.

628. Tamayose K, Sugimoto K, Ando M, Oshimi K. Mononucleosis syndrome and acute monocytic leukemia. Eur J Haematol. 2002;68:236-8.

629. Eun YB, Bo KK, Seok GC, Jin WK. A case of disseminated herpes zoster with thrombocytopenia. Korean J Dermatol. 2005;43:410-12.

630. Kawano N, Gondo H, Kamimura T, Aoki K, lino T, Ishikawa F, et al. Chronic graft-versus-host disease following varicella-zoster virus infection in allogeneic stem cell transplant recipients. Int J Hematol. 2003;78:370-3.

631. Park BC, Choe YS, Kim DW, Lee WJ, Lee SJ, Na GY. Clinical study on dermatologic disease of the elderly. Korean J Dermatol. 2006;44:818-23.

632. Furue $M$, Yamazaki S, Jimbow $K$, Tsuchida T, Amagai M, Tanaka T, et al. Prevalence of dermatological disorders in Japan: a nationwide, cross-sectional, seasonal, multicenter, hospital-based study. J Dermatol. 2011;38:310-20.

633. Yoon NY, Hong SP, Jeon SY, Shin JS, Ahn SK. A clinical study of dermatologic diseases in elderly patients. Korean J Dermatol. 2011;49: 887-95.

634. Go JW, Cho HK, Kang WH, Ro Bl. A statistical study of dermatoses in Goyang City (2004 2008). Korean J Dermatol. 2009;47:896-903.

635. Choi HS, Yun SK, Kim HU, Ihm CW. A statistical study of dermatoses in the Jeonbuk Province (1979-1980, 1987-2002). Korean J Dermatol. 2005;43:606-18.

636. Hong S, Lee ES, Yoon KH. A statistical study of dermatoses in the Suwon area and southern area of Kyonggi (1995-2001). Korean J Dermatol. 2003;41: 728-39.

637. Shin BJ, Choe SW, Seo SJ, Hong CK. A clinical study of skin diseases in elderly patients(IV). Korean J Dermatol. 2002:40:1346-52.

638. Wang E, Lim BL, Than KY. Dermatological conditions presenting at an emergency department in Singapore. Singapore Med J. 2009;50:881-4.

639. Chan CY, Kam KL, Graham CA, Rainer TH, Luk NM. Clinical profile of skin diseases in accident and emergency department attenders. Hong Kong J Dermatol Venereol. 2007;15:4-9.

640. Zhang Y, Zhou SX, Zhang TF, Huang GF. Analysis of the distribution of diseases in 6435 inpatients from the department of acupuncture and moxibustion. Zhongguo Zhen Jiu. 2011;31:941-4.

641. Park EJ, Han KR, Kim DW, Kim C. A clinical survey of the patients in neuropain clinic at Ajou University. Korean J Pain. 2007;20:181-5.

642. Ministry of Health. Immunisation Handbook 2014 (3rd edn). Wellington: Ministry of Health. 2016. http://www.health.govt.nz/system/files/documents/ publications/imm-handbk-2014-3rd-edn-dec16.pdf. Accessed 17 Jan 2017.

643. Gan EY, Tian EA, Tey HL. Management of herpes zoster and post-herpetic neuralgia. Am J Clin Dermatol. 2013;14:77-85.

644. Wehrhahn MC, Dwyer DE. Herpes zoster: Epidemiology, clinical features, treatment and prevention. Aust Prescr. 2012;35:143-7.

645. Cunningham AL, Litt J. Shingles: How to prevent it, how to treat it. Med Today. 2014;15:20-7.

646. Cunningham AL, Breuer J, Dwyer DE, Gronow DW, Helme RD, Litt JC, et al. The prevention and management of herpes zoster. Med J Aust. 2008;188:171-6.

647. Chopra A, Jassal JS, Bahl RK. Role of acyclovir and laser therapy in herpes zoster. Indian J Dermatol Venereol Leprol. 1994;60:208-9.

648. Hayashibe K, Ichihashi M. Efficacy of acyclovir 400 mg tablet (Zovirax ${ }^{\oplus}$ tablet 400) in herpes zoster. Skin Res. 1994;36:543-50.

649. Sugiyama Y, Tamura T, Seguchi T, Yoshida M, Tezuka T. Evaluation of efficacy of oral acyclovir in herpes zoster Trial of $2400 \mathrm{mg} 3$ times daily. Skin Res. 1994;36:459-64.

650. Yoshikawa K, Doi T. Clinical evaluation of Zovirax ${ }^{\oplus}$ (acyclovir) tablet 400 on herpes zoster. Skin Res. 1994;36:441-58.

651. Chen YH. Observation of oral acyclovir combined with sodium hyaluronate and fluorometholone eye drops on the treatment of herpes zoster keratitis. Intern Eye Sci. 2014;14:729-30.

652. McDonald EM, de Kock J, Ram FS. Antivirals for management of herpes zoster including ophthalmicus: a systematic review of high-quality randomized controlled trials. Antivir Ther. 2012;17:255-64. 
653. Lin WR, Lin HH, Lee SS, Tsai HC, Huang CK, Wann SR, et al. Comparative study of the efficacy and safety of valaciclovir versus acyclovir in the treatment of herpes zoster. J Microbiol Immunol Infect. 2001;34:138-42.

654. Shen MC, Lin HH, Lee SS, Chen YS, Chiang PC, Liu YC. Double-blind, randomized, acyclovir-controlled, parallel-group trial comparing the safety and efficacy of famciclovir and acyclovir in patients with uncomplicated herpes zoster. J Microbiol Immunol Infect. 2004;37:75-81.

655. Chen A, Sun X. Comparative study of treatment of herpes zoster with valaciclovir and acyclovir. Med J Wuhan Univ. 2006;27:537-8.

656. Gopal MG, Shannoma, Sharath Kumar BC, Ramesh M, Nandini AS, Manjunath NC. A comparative study to evaluate the efficacy and safety of acyclovir and famciclovir in the management of herpes zoster. J Clin Diagn Res. 2013;7:2904-7.

657. Liao R, Wu J, Yang H. Contrast of acycloguanosine, famciclovir, ribavirin in treatment of herps zoster pruritus. Chin J Clin Rehab. 2003;7:904-5.

658. Li W, Guo ZP, Xiong L. Domestic penciclovir powder through injection for improving cutaneous deficiency and residual neuralgia in patients with herpes zoster: A randomized, double-blind and controlled trial. Chin J Clin Rehab. 2005;9:34-7.

659. Sodhi PK, Ratan SK. A case of chronic renal dysfunction following treatment with oral acyclovir. Scand J Infect Dis. 2003;35:770-2.

660. Kitching AR, Fagg D, Hay NM, Hatfield PJ, Macdonald A. Neurotoxicity associated with acyclovir in end stage renal failure. New Zealand Med J. 1997;110:167-9.

661. Takayanagi A, Maehana T, Kyoda Y, Yanase M. Neurotoxicity of valacyclovir in a peritoneal dialysis patient. Hinyokika Kiyo. 2010;56:617-9.

662. Asahi T, Tsutsui M, Wakasugi M, Tange D, Takahashi C, Tokui K, et al. Valacyclovir neurotoxicity: clinical experience and review of the literature. Eur J Neurol. 2009;16:457-60.

663. Yang HH, Hsiao YP, Shih HC, Yang JH. Acyclovir-induced neuropsychosis successfully recovered after immediate hemodialysis in an end-stage renal disease patient. Int J Dermatol. 2007:46:883-4.

664. Fujii $H$, Tanioka M, Matsumura Y, Miyachi Y, Matsubara T. A case of valaciclovir induced encephalopathy in a patient with peritoneal dialysis. Skin Res. 2007:6:372-5.

665. Sagawa N, Tsurutani Y, Nomura K, Okuyama T, Kondo M, Sata A, et al. Acyclovir-Induced neurotoxicity and acute kidney injury in an elderly diabetic patient treated with valacyclovir: Report of a case. Nihon Ronen Igakkai Zasshi. 2014;51:581-5.

666. Ng HW, Pang CT. Confusion in patients with shingles and renal failure: Acyclovir neurotoxicity or herpes encephalitis. Hong Kong J Emerg Med. 2012;19:205-9.

667. Matsumoto R, Yoshida T, Tabata KI, Nakagawa SI, Yanagisawa N. A patient with thyroid carcinoma who developed consciousness disturbance during acyclovir administration for herpes zoster. Clin Neurol. 1996;36:590-3.

668. Mihara A, Mori T, Nakazato T, Ikeda Y, Okamoto S. Acute renal failure caused by intravenous acyclovir for disseminated varicella zoster virus infection. Scand J Infect Dis. 2007;39:94-5.

669. Yamamoto Y, Suganuma A, Mishima N, Horibe C, Saito Y. A case of acute renal failure due to valacyclovir in an elderly patient with progressive supranuclear palsy. IRYO Jpn J Natl Med Serv. 2009;63:735-9.

670. Kusakari Y, Tanita M, Egawa T, Yoshida H, Shingou T, Nakamura K, et al. Efficacy and safety of famciclovir for the treatment of herpes zoster patients with renal dysfunction. Nishinihon J Dermatol. 2014;76:44-51.

671. Yoon H, Rhew KY. Famciclovir as an antiviral agent for a patient with acute renal failure. Int J Clin Pharm. 2013;35:173-5.

672. Okamoto S, Ishibashi Y, Inoue Y, Uchio E, Ohashi Y, Kitagawa K, et al. Multicentered survey of ocular complications of acyclovir ophthalmic ointment. Jpn J Clin Ophthalmol. 1997;51:1112-4.

673. Zhang JS. Clinical effect comparison of ganciclovir ophthalmic gel and ganciclovir eye drops in the treatment of herpes zoster keratitis. Int J Ophthalmol. 2011;11:309-10.

674. Li SQ, Jia J, Zhang ZY. Clinical observation on eyelid herpes zoster with external use ganciclovir ophthalmic gel. Intern Eye Sci. 2014;14:1356-7.

675. Nakamura H, Ishimoto S, Fujisawa K, Okada T, Tahara Y, Nakamura T, et al. Systemic ganciclovir with vitrectomy was effective in two cases of acute retinal necrosis. Jpn J Clin Ophthalmol. 1999:53:1599-603.

676. Lee MY, Kim KS, Lee WK. Intravitreal foscarnet for the treatment of acyclovirresistant acute retinal necrosis caused by varicella zoster virus. Ocul Immunol Inflamm. 2011;19:212-3.
677. Hwangbo H, Jung SW, Son HH, Lee SK. Comparison between famciclovir and valacyclovir for the treatment of herpes zoster in adults. Korean J Dermatol. 2014;52:720-7.

678. Ono F, Yasumoto S, Furumura M, Hamada T, Ishii N, Gyotoku T, et al. Comparison between famciclovir and valacyclovir for acute pain in adult Japanese immunocompetent patients with herpes zoster. J Dermatol. 2012;39:902-8.

679. Bodsworth NJ, Boag F, Burdge D, Généreux M, Borleffs JC, Evans BA, et al. Evaluation of sorivudine (BV-araU) versus acyclovir in the treatment of acute localized herpes zoster in human immunodeficiency virusinfected adults. The Multinational Sorivudine Study Group. J Infect Dis 1997;176:103-11.

680. Watabe T, Okuda H, Ogura K. Lethal drug interactions of the new antiviral, sorivudine, with anticancer prodrugs of 5-fluorouracil. Yakugaku Zasshi. 1997;117:910-21.

681. Chen N, Li Q, Yang J, Zhou M, Zhou D, He L. Antiviral treatment for preventing postherpetic neuralgia. Cochrane Database Syst Rev. 2014;2: CD006866.

682. Liu G, Zhan H, Deng R. A clinical study of 32 Hunt syndrome. Acta Acad Med Hubei. 1996;17:73.

683. Ho KY, Pasutharnchat K. Intrathecal dexamethasone for the treatment of intractable postherpetic neuralgia: A case report. Internet J Pain Symptom Control Palliative Care. 2009;6:4.

684. Achar A, Chakraborty PP, Bisai S, Biswas A, Guharay T. Comparative study of clinical efficacy of amitriptyline and pregabalin in postherpetic neuralgia. Acta Dermatovenerol Croat. 2012;20:89-94.

685. Wrigley P, Cousins M. Postherpetic neuralgia: An update on management and prevention. Med Today. 2008;9:36-44.

686. Kochar DK, Agarwal RP, Joshi A, Kumawat BL. Herpes zoster and postherpetic neuralgia - a clinical trial of aspirin in chloroform for anodyne. J Assoc Physicians India. 1998;46:337-40.

687. Kanodia SK, Singhal KC. A study on efficacy of Pregabalin in acute Herpetic Neuralgia. Ann Neurosci. 2011;18:148-50.

688. Kanodia SK, Seth AK, Dixit AM. Dose related efficacy of gabapentin in acute herpetic neuralgia among geriatric patients. Indian J Dermatol. 2012;57:362-5.

689. Sabatowski R, Galvez R, Cherry DA, Jacquot F, Vincent E, Maisonobe P, et al. Pregabalin reduces pain and improves sleep and mood disturbances in patients with post-herpetic neuralgia: Results of a randomised, placebocontrolled clinical trial. Pain. 2004;109:26-35.

690. Meng FY, Zhang LC, Liu Y, Pan LH, Zhu M, Li CL, et al. Efficacy and safety of gabapentin for treatment of postherpetic neuralgia: a meta-analysis of randomized controlled trials. Minerva Anestesiol. 2014;80:556-7.

691. Doggrell SA. Pregabalin or morphine and gabapentin for neuropathic pain. Expert Opin Pharmacother. 2005;6:2535-9.

692. Zhang LX, Li GL. Effect of oxycodone-acetaminophen therapy in patients with intractable postherpetic neuralgia. Chin J New Drugs. 2009;18:427-8.

693. Zhao G, Zhang H. Analgesic effect of oxycodone-acetaminophen tablets on herpes zoster. Chin J New Drugs. 2009;18:720-1.

694. Liu GH, Liu JM. Efficacy of oxycodone-acetamainophen on postherpetic neuralgia in patients with zoster. Chin J New Drugs. 2009;18:722-3. 740.

695. Wu XM, Zhu SM. Effect of oxycodone-acetaminophen in 58 patients with herpes zoster. Chin J New Drugs. 2009;18:718-9. 721.

696. Yang Y, Yan JQ, Guo QL, Chen ZG. Safety and efficacy of oral oxycodoneacetaminophen versus tramadol in treatment of postherpetic neuralgia. Chin J New Drugs. 2009;18:527-9.

697. Lin PL, Fan SZ, Huang CH, Huang HH, Tsai MC, Lin CJ, et al. Analgesic effect of lidocaine patch $5 \%$ in the treatment of acute herpes zoster: a doubleblind and vehicle-controlled study. Reg Anesth Pain Med. 2008;33:320-5.

698. Garnock-Jones KP, Keating GM. Lidocaine 5\% medicated plaster: a review of its use in postherpetic neuralgia. Drugs. 2009;69:2149-65.

699. Iseki M, Mitsuhata H, Miyazaki T, Toriumi E, Yoshino K. Relief of subacute herpetic pain and postherpetic neuralgia with repeated application of $10 \%$ lidocaine cream. Jpn J Anesthesiol. 2000;49:1204-9.

700. Cousins MJ, Pickthorn K, Huang S, Critchley L, Bell G. The safety and efficacy of KAl-1678- an inhibitor of epsilon protein kinase C ( $($ PKC)-versus lidocaine and placebo for the treatment of postherpetic neuralgia: a crossover study design. Pain Med. 2013;14:533-40.

701. Chen SM, Chen JT, Kuan TS, Hong CZ. Myofascial trigger points in intercostal muscles secondary to herpes zoster infection of the intercostal nerve. Arch Phys Med Rehabil. 1998;79:336-8. 
702. Xiao LZ, Zhang DR, Jiang J, Zhang KL, Zhang M, Zhu HQ. Feasibility of transdermal fentanyl for pain relief of herpes zoster and postherpetic neuralgia. Chin J Clin Rehab. 2004;8:216-7.

703. Lee GY. The effect of fentanyl patch in the treatment of intractable postherpetic neuralgia. Korean J Dermatol. 2007;45:422-8.

704. Guo WJ, Xiao ZY, Yang YX. Effectiveness of transdermal fentanyl combined with clodine for pain control of acute herpes zoster. J Dalian Med Univ. 2007;29:255-6

705. Pan BC, Hou XW, Li XP. Curative effect of recombinant human interferon a2b gel combined with aciclovir on herpes zoster. Chin J Biol. 2008;21:711-2.

706. Miyoshi H, Hirotsuji N, Kino T, Katsu K. Interferon alpha gel for herpes zoster. Dermatology. 1997;194:306

707. Akimoto T. Clinical evaluation of 3\% Ara-A ointment on herpes zoster and herpes simplex. Skin Res. 1995;37:164-79.

708. Ishii N, Baba N, Nakajima H, Yoshida S, Katoh Y. Clinical studies of Arasena$A^{\oplus}$ ointment I Clinical effects on herpes zoster. Skin Res. 1994;36:220-7.

709. Shann F. Povidone-iodine for herpes zoster. Lancet. 2004;364:502

710. Sun W, Xiang X, Zeng X. Compound ribavirin paint: Preparation and application. Chin Pharm J (China). 1996;31:150-3.

711. Keam SJ, Chapman TM, Figgitt DP. Brivudin (bromovinyl deoxyuridine). Drugs. 2004;64:2091-7.

712. Kanai A, Osawa S, Suzuki A, Ishimaru R, Hoka S. Effectiveness of prostaglandin $\mathrm{E} 1$ for the treatment of patients with neuropathic pain following herpes zoster. Pain Med. 2007;8:36-40.

713. Kanai A, Wang G, Hoshi K, Okamoto H. Effects of intravenous prostaglandin E1 on pain and body temperature in patients with post-herpetic neuralgia. Pain Med (USA). 2010;11:609-16.

714. Lu YG, Wu JJ, Yang YD. Study of efficacy of Lipo PGE1 in treatment of postherpetic neuralgia in patients with herpes zoster. Chin J Clin Rehab. 2002;6:3092-3.

715. Kushida Y, Yoshida M, Akaike Y, Yamada K, Nishizuka K, Kita M, et al. The effects of Lipo-PGE1 on shooting pain of postherpetic neuralgia. Hokuriku J Anesthesiol. 1999;33:59-62.

716. Fujii K, Kanno Y, Konishi K, Ohgou N. A specific thrombin inhibitor, argatroban, alleviates herpes zoster-associated pain. J Dermatol. 2001;28:200-7.

717. Komori M, Fukuuchi A, Mae T, Nishiyama K, Kawamata M, Ozaki M. Milnacipran hydrochloride for the treatment of postherpetic neuralgia. Pain Clinic. 2006:18:421-3.

718. Sekiguchi T, Fujihara K, Sato H. Clinical effects of immunoglobulin (Polyglobin ${ }^{\circledR} \mathrm{N}$ ) for severe infectious disorders in dermatology. Jpn Pharmacol Ther. 1995;23:195-208.

719. Xu G, Lv ZW, Feng Y, Tang WZ, Xu GX. A single-center randomized controlled trial of local methylcobalamin injection for subacute herpetic neuralgia. Pain Med. 2013;14:884-94.

720. Han G, Kim SH, Lee KS, Cho JW. Effect of botulinum toxin a on acute and chronic pain in herpes zoster patients. Korean J Dermatol. 2014;52: 845-50.

721. Zacest A, Anderson VC, Burchiel KJ. The glass half empty or half full - how effective are long-term intrathecal opioids in post-herpetic neuralgia? A case series and review of the literature. Neuromodulation. 2009;12:219-23.

722. Ji G, Niu J, Shi Y, Hou L, Lu Y, Xiong L. The effectiveness of repetitive paravertebral injections with local anesthetics and steroids for the prevention of postherpetic neuralgia in patients with acute herpes zoster. Anesth Analg. 2009;109:1651-5.

723. Ji CM, Li XM, Sun DH, Jiang CL, Li SL. Clinical study on stellate ganglion block combined with pregabalin for treating postherpetic neuralgia at chest and back. Chin J New Drugs. 2012;21:1503-6.

724. Wang JS. The comparison of therapeutic effect of three methods for the treatment of acute herpes zoster. Curr Opin Clin Exp Res. 2002;4:12-5.

725. Manabe H, Dan K, Hirata K, Hori K, Shono S, Tateshi S, et al. Optimum pain relief with continuous epidural infusion of local anesthetics shortens the duration of zoster-associated pain. Clin J Pain. 2004;20:302-8.

726. Bhargava R, Bhargava S, Haldia KN, Bhargava P. Jaipur block in postherpetic neuralgia. Int J Dermatol. 1998:37:465-8.

727. Puri N. Modified Jaipur block for the treatment of post-herpetic neuralgia. Int J Dermatol. 2011:50:1417-20.

728. Chaturvedi A, Dash HH. Sympathetic blockade for the relief of chronic pain. J Indian Med Assoc. 2001:99:698-703.

729. Hwang SM, Kang YC, Lee YB, Yoon KB, Ahn SK, Choi EH. The effects of epidural blockade on the acute pain in herpes zoster. Arch Dermatol. 1999; 135:1359-64.
730. Ahn HJ, Lim HK, Lee YB, Hwang SM, Lee WS, Ahn SK, et al. The effects of famciclovir and epidural block in the treatment of herpes zoster. J Dermatol. 2001;28:208-16.

731. Ahn SY, Lee YB, Lee KH, Lim HK, Lee WS, Ahn SK, et al. The effect of stellate ganglion block on herpes zoster. Korean J Dermatol. 2006;44:681-7.

732. Jun JH, Ro YS, Kim JH, Shim JC. The effects of continuous epidural blockade in the treatment of postherpetic neuralgia. Korean J Dermatol. 1998:36:584-8.

733. Koh WS, Park SM, Kim BS, Shin DY. The effect of sympathetic blocks in the prevention of postherpetic neuralgia. Korean J Dermatol. 1997;35:620-6.

734. Shin HY, Kim DS, Kim SS. Superficial cervical plexus block for management of herpes zoster neuralgia in the C3 dermatome: a case report. J Med Case Rep. 2014;8:59.

735. Lee JY, Sim WS, Kim KM, Oh MS, Lee JE. The effect of ketamine as an additive in epidural block on the intractable herpetic neuralgia: a case report. Korean J Anesthesiol. 2014;66:64-6.

736. Chau SW, Soo LY, Lu DV, Chen TI, Cheng KI, Chu KS. Clinical experience of pain treatment for postherpetic neuralgia in elderly patients. Acta Anaesthesiol Taiwan. 2007:45:95-101.

737. Dan K. Nerve block therapy and postherpetic neuralgia. Crit Rev Phys Rehabil Med. 1995;7:93-112.

738. Higa K, Hori K, Harasawa I, Hirata K, Dan K. High thoracic epidural block relieves acute herpetic pain involving the trigeminal and cervical regions: Comparison with effects of stellate ganglion block. Reg Anesth. 1998;23:25-9.

739. Mizuno J, Sugimoto S, Ikeda M, Kamakura T, Machida K, Kusume S. Treatment with stellate ganglion block, continuous epidural block and ulnar nerve block of a patient with postherpetic neuralgia who developed complex regional pain syndrome (CRPS). Jpn J Anesthesiol. 2001:50:548-51.

740. Tajima K, Iseki M, Inada E, Miyazaki T. The effects of early nerve blocks for prevention of postherpetic neuralgia and analysis of prognostic factors. Jpn J Anesthesiol. 2009;58:153-9.

741. Tajima K, Kawagoe I, Kanai M, Mitsuhata H. Effective treatment of acute pain and related symptoms in elderly with herpes zoster. Jpn J Anesthesiol. 2008; 57:874-8.

742. Kishimoto N, Kato J, Suzuki T, Arakawa H, Ogawa S, Suzuki H. A case of RSD with complete disappearance of symptoms following intravenous ketamine infusion combined with stellate ganglion block and continuous epidural block. Jpn J Anesthesiol. 1995:44:1680-4.

743. Tsai YC, Wang LK, Chen BS, Chen HP. Home-based patient-controlled epidural analgesia with bupivacaine for patients with intractable herpetic neuralgia. J Formos Med Assoc. 2000;99:659-62.

744. Kang FC, Chang PJ, Chen HP, Tsai YC. Patient-controlled epidural analgesia for postherpetic neuralgia in an HIV-infected patient as a therapeutic ambulatory modality. Acta Anaesthesiol Sin. 1998;36:235-9.

745. Okano K, Kondo H, Tsuchiya R, Naruke T, Sato M, Yokoyama R. Spinal epidural abscess associated with epidural catheterization: report of a case and a review of the literature. Jpn J Clin Oncol. 1999:29:49-52.

746. Taga K, Tomita M, Watanabe I, Sato K, Awamori K, Fujihara H, et al. Complete recovery of consciousness in a patient with decorticate rigidity following cardiac arrest after thoracic epidural injection. Br J Anaesth. 2000;85:632-4.

747. Iseki M, Okuno S, Tanabe Y, Mitsuhata H, Miyazaki T. Methicillin-resistant Staphylococcus aureus sepsis resulting from infection in paravertebral muscle after continuous epidural infusion for pain control in a patient with herpes zoster. Anesth Analg. 1998:87:116-8.

748. Hamaguchi K, Ikegami S, Morita N, Fukushima H, Miyata K, Fujiki N, et al. A case of dyspnea caused by deep cervical hematoma following stellate ganglion block. Pract Oto-Rhino-Laryngol. 2007;100:391-5.

749. Miyamoto T, Nakatani T, Narai Y, Sakakibara M, Hashimoto T, Saito Y. A case of spinal epidural abscess after continuous epidural block to manage the pain of herpes zoster. Jpn J Anesthesiol. 2014;63:353-7.

750. Son H, Sakuma Y, Kamada T, Kawano M, Suwa I, Kotani J, et al. A patient with respiratory arrest after stellate ganglion blockade. J Jpn Dent Soc Anesthesiol. 1996:24:489-92.

751. Sugino N, Ohta A, Abe H, Mori H. Three cases of bacterial contaminations associated with epidural catheterization in patients of herpes zoster. Hokuriku J Anesthesiol. 1995:29:47-9.

752. Suzuki T, Takemura H, Shida K, Higuchi H, Ohtsuka N, Masuda Y. The development of methicillin-resistant Staphylococcus aureus sepsis in a patient with herpes zoster during treatment with continuous epidural infusion. Jpn J Anesthesiol. 2002;51:293-5. 
753. Uematsu $H$, Hiei K, Kawasaki $H$. Unknown fever and abnormal liver functions after repeated epidural blocks with lidocaine for management of herpes zoster pain. Jpn J Anesthesiol. 1994;43:405-8.

754. Wajima Z, Ishikawa G, Kaneko K, Inoue T, Ogawa R. A case of using continuous double-tapped epidural analgesia for herpes zoster duplex. Jpn J Anesthesiol. 1995:44:841-4.

755. Jeon Y, Baek SU, Yeo JS. Spinal myoclonus developed during cervical epidural drug infusion in postherpetic neuralgia patient. Korean J Pain. 2011;24:169-71.

756. Min BM, Kim JH. Epidural catheterization with a subcutaneous injection port for the long-term administration of opioids and local anesthetics to treat zoster-associated pain -a report of two cases-. Korean J Anesthesiol. 2013;65:462-7.

757. Higa K, Shono S, Nitahara K. Postherpetic neuralgia. Jpn J Anesthesiol. 2010; 59:1342-9.

758. Moryama K. Effect of temporary spinal cord stimulation on postherpetic neuralgia in the thoracic nerve area. Neuromodulation. 2009;12:39-43.

759. Hirabayashi H, Kawata K, Hoshida T, Tamura K, Youngsu P, Nakase H. Neuromodulation therapy for neuropathic pain. Jpn J Neurosurg. 2011;20:93-102.

760. Hijikata Y, Yamada S. Effect of Ganoderma lucidum on postherpetic neuralgia. Am J Chin Med. 1998;26:375-81

761. Hijikata Y, Yasuhara A, Sahashi Y. Effect of an herbal formula containing Ganoderma lucidum on reduction of herpes zoster pain: a pilot clinical trial. Am J Chin Med. 2005;33:517-23.

762. Nakanishi M, Arimitsu J, Kageyama M, Otsuka S, Inoue T, Nishida S, et al. Efficacy of traditional Japanese herbal medicines-Keishikajutsubuto (TJ-18) and Bushi-matsu (TJ-3022)-against postherpetic neuralgia aggravated by self-reported cold stimulation: a case series. J Altern Complement Med. 2012;18:686-92.

763. Lee SM, Lim J, Lee JD, Choi DY, Lee S. Bee venom treatment for refractory postherpetic neuralgia: a case report. J Altern Complement Med. 2014;20: 212-4.

764. Byun SH, Jeon Y. Administration of Vitamin C in a Patient with Herpes Zoster - A case report -. Korean J Pain. 2011;24:108-11.

765. Huang B, Zhou XY, Lu YP, Zhu ZF, Hou J, Sun JL, et al. Selective percutaneous dorsal root ganglion radiofrequency thermocoagulation guided by CT scanning in treatment of post-herpetic neuralgia. Nat Med $J$ China. 2008:88:885-8.

766. Lim SM, Park HL, Moon HY, Kang KH, Kang H, Baek CH, et al. Ultrasound-guided infraorbital nerve pulsed radiofrequency treatment for intractable postherpetic neuralgia - a case report -. Korean J Pain. 2013;26:84-8.

767. Ko YK, Lee HY, Lee WY. Clinical experiences on the effect of scrambler therapy for patients with postherpetic neuralgia. Korean J Pain. 2013;26:98-101.

768. Chen HM. Zoster Chinese medicine treatment. Zhonghua Shi Yan He Lin Chuang Bing Du Xue Za Zhi. 2007;21:285-7.

769. Cao H, Li X, Liu J. An updated review of the efficacy of cupping therapy. PLoS One. 2012;7:e31793.

770. Bourke A, Hui B. Weak evidence that HBOT is of benefit in the treatment of patients with herpes zoster. Diving Hyperbaric Med. 2013;43:174.

771. National Centre for Immunisation Research \& Surveilance. Zoster vaccine for Australian adults | NCIRS Fact sheet: July 2015. http://www.ncirs.edu.au/ assets/provider_resources/fact-sheets/herpes-zoster-vaccine-fact-sheet.pdf. Accessed 3 Sept 2015.

772. Fujiwara O, Mitamura Y, Ohtsuka K. Herpes zoster panuveitis progression despite acyclovir treatment in a patient following bone marrow transplantation. Jpn J Ophthalmol. 2005;49:536-8.

773. Abe T, Kuboki J, Tamai M. Sensitivity to acyclovir in acute retinal necrosis syndrome. Jpn J Clin Ophthalmol. 1997;51:1161-3.

774. Leung AY, Chow HC, Kwok JS, Lui CK, Cheng VC, Yuen KY, et al. Safety of vaccinating sibling donors with live-attenuated varicella zoster vaccine before hematopoietic stem cell transplantation. Bone Marrow Transplant. 2007:39:661-5.

775. Kanda Y, Mineishi S, Saito T, Saito A, Yamada S, Ohnishi M, et al. Long-term low-dose acyclovir against varicella-zoster virus reactivation after allogeneic hematopoietic stem cell transplantation. Bone Marrow Transplant. 2001; 28:689-92.

776. Kawamura K, Wada H, Yamasaki R, Ishihara Y, Sakamoto K, Ashizawa M, et al. Prophylactic role of long-term ultra-low-dose acyclovir for varicella zoster virus disease after allogeneic hematopoietic stem cell transplantation. Int J Infect Dis. 2014;19:26-32.
777. Uchiyama M, Tamai Y, Ikeda T. Low-dose acyclovir against reactivation of varicella zoster virus after unrelated cord blood transplantation. Int J Infect Dis. 2010;14:e451-2.

778. Asano-Mori Y, Kanda Y, Oshima K, Kako S, Shinohara A, Nakasone H, et al. Long-term ultra-low-dose acyclovir against varicella-zoster virus reactivation after allogeneic hematopoietic stem cell transplantation. Am J Hematol. 2008;83:472-6.

779. Oshima K, Takahashi T, Mori T, Matsuyama T, Usuki K, Asano-Mori Y, et al. One-year low-dose valacyclovir as prophylaxis for varicella zoster virus disease after allogeneic hematopoietic stem cell transplantation. A prospective study of the Japan Hematology and Oncology Clinical Study Group. Transpl Infect Dis. 2010;12:421-7.

780. Aoki T, Nishiyama T, Imahashi N, Kitamura K. Efficacy of continuous, daily, oral, ultra-low-dose $200 \mathrm{mg}$ acyclovir to prevent herpes zoster events among bortezomib-treated patients: a report from retrospective study. Jpn J Clin Oncol. 2011;41:876-81.

781. Fukushima T, Sato T, Nakamura T, Iwao H, Nakajima A, Miki M, et al. Daily $500 \mathrm{mg}$ valacyclovir is effective for prevention of Varicella zoster virus reactivation in patients with multiple myeloma treated with bortezomib. Anticancer Res. 2012;32:5437-40.

782. Steer CB, Szer J, Sasadeusz J, Matthews JP, Beresford JA, Grigg A. Varicellazoster infection after allogeneic bone marrow transplantation: Incidence, risk factors and prevention with low-dose aciclovir and ganciclovir. Bone Marrow Transplant. 2000;25:657-64

783. Takahashi M, Kamiya H, Asano Y, Shiraki K, Baba K, Otsuka T, et al. Immunization of the elderly to boost immunity against varicella-zoster virus (VZV) as assessed by VZV skin test reaction. In: Gershon AA, Arvin AM, Calisher $\mathrm{CH}$, editors. Archives of Virology, Supplement 17: Immunity to and prevention of herpes zoster. Vienna: Springer; 2001. p. 161-72. doi:10.1007/ 978-3-7091-6259-0_17.

784. Takahashi M, Okada S, Miyagawa H, Amo K, Yoshikawa K, Asada H, et al. Enhancement of immunity against VZV by giving live varicella vaccine to the elderly assessed by VZV skin test and IAHA, gpELISA antibody assay. Vaccine. 2003;21:3845-53.

785. Hata A, Inoue F, Yamasaki M, Fujikawa J, Kawasaki Y, Hamamoto Y, et al. Safety, humoral and cell-mediated immune responses to herpes zoster vaccine in subjects with diabetes mellitus. J Infect. 2013;67:215-9.

786. Marumoto T, Ono K. Varicella vaccine was effective in a case of recurrent ophthalmic zoster sine herpete. Jpn J Clin Ophthalmol. 2013;67:575-9.

787. Sasadeusz J, Prince HM, Schwarer A, Szer J, Stork A, Bock HL, et al. Immunogenicity and safety of a two-dose live attenuated varicella vaccine given to adults following autologous hematopoietic stem cell transplantation. Transplant Infect Dis. 2014;16:1024-31.

788. Cheuk DK, Chiang AK, Lee TL, Chan GC, Ha SY. Vaccines for prophylaxis of viral infections in patients with hematological malignancies. Cochrane Database Syst Rev. 2011;3:CD006505.

789. Frazer $\mid H$, Levin MJ. Paradigm shifting vaccines: prophylactic vaccines against latent varicella-zoster virus infection and against HPV-associated cancer. Curr Opin Virol. 2011;1:268-79.

790. Choi WS. Herpes zoster vaccine in Korea. Clin Exp Vaccine Res. 2013;2:92-6.

791. Recommended immunization schedule for adults in Korea, by the Korean Society of Infectious Diseases, 2012. Clin Exp Vaccine Res. 2014; 3:110-2.

792. Chun GTW, Chong LP, Bailey P. Malaysian Society of Geriatric Medicine position statement on vaccination against the herpes zoster virus in older adults (updated June 2014). https://sites.google.com/a/ummc.edu.my/ msgm/position-statements/the-herpes-zoster-vaccine. Accessed 2 Feb 2015

793. Specialist Doctors Association of Indonesia. Adult Immunization Schedule. 2014. http://pbpapdi.net/images/file_unduh/Catatan Imunisasi \&Jadwal Imunisasi Dewasa_103.zip. Accessed 18 Jan 2017.

794. Philippine Society for Microbiology and Infectious Diseases. Handbook on Adult Immunization for Filipinos. 2012. www.psmid.org.ph/contents/ handbook-on-adult-immunization-2012.pdf. Accessed 1 Apr 2015.

795. Thailand Royal College of Physicians. Recommended Adult and Elderly Immunization Schedule, 2014. www.rcpt.org/index.php/2012-10-03-16-53-39/ category/6-2013-02-02-09-02-52.html?download=140:-2014. Accessed 1 Apr 2015.

796. Taiwan Association of Family Medicine. Clinical Handbook for Adult Immunization. 1st ed. Taipei: Taiwan Association of Family Medicine; 2010. p. 31-6.

797. Chen N, Li Q, Zhang Y, Zhou M, Zhou D, He L. Vaccination for preventing postherpetic neuralgia. Cochrane Database Syst Rev. 2011;3:CD007795. 
798. Loke XY, Tran W, Alderman CP. Survey of Australian inpatients on vaccination status and perceptions of influenza vaccination. Consult Pharm. 2012;27:553-63.

799. Macaladad N, Marcano T, Guzman M, Moya J, Jurado F, Thompson M, et al. Safety and immunogenicity of a zoster vaccine in varicella-zoster virus seronegative and low-seropositive healthy adults. Vaccine. 2007;25:2139-44.

800. Hales CM, Harpaz R, Ortega-Sanchez I, Bialek SR. Centers for Disease Control and Prevention (CDC). Update on recommendations for use of herpes zoster vaccine. MMWR Morb Mortal Wkly Rep. 2014;63:729-31.

801. Keating GM. Shingles (herpes zoster) vaccine (zostavax ${ }^{\oplus}$ ): a review of its use in the prevention of herpes zoster and postherpetic neuralgia in adults aged $\geq 50$ years. Drugs. 2013;73:1227-44.

802. World Health Organization, SAGE Working Group on Varicella and Herpes Zoster Vaccines. Background paper on herpes zoster. SAGE Meeting 1-3 April 2014, Geneva, Switzerland. at: http://www.who.int/immunization/sage/ meetings/2014/april/2_Background_document_Herpes_Zoster.pdf. Accessed 3 Oct 2016.

803. Association of Physicians of India. Medicine Update (Volume 23, 2013). Adult immunization. http://www.apiindia.org/medicine_update_2013/chap101.pdf. Accessed 9 Feb 2015.

804. Maclntyre CR, Egerton T, McCaughey M, et al. Concomitant administration of zoster and pneumococcal vaccines in adults $\geq 60$ years old. Hum Vaccin. 2010;6:894-902.

805. Tseng HF, Smith N, Sy LS, Jacobsen SJ. Evaluation of the incidence of herpes zoster after concomitant administration of zoster vaccine and polysaccharide pneumococcal vaccine. Vaccine. 2011;29:3628-32.

806. United States Census Bureau, International Programs, International Data Base. Revised December 19, 2013. https://www.census.gov/population/ international/data/idb/informationGateway.php. Accessed 8 May 2015

807. Maclntyre R, Stein A, Harrison C, Britt H, Mahimbo A, Cunningham A, Thompson R. Increasing Trends of Herpes Zoster in Australia. PLoS One. 2015;10:e0125025

\section{Submit your next manuscript to BioMed Central and we will help you at every step:}

- We accept pre-submission inquiries

- Our selector tool helps you to find the most relevant journal

- We provide round the clock customer support

- Convenient online submission

- Thorough peer review

- Inclusion in PubMed and all major indexing services

- Maximum visibility for your research

Submit your manuscript at www.biomedcentral.com/submit 